\title{
Upper-level circulation in the South Atlantic Ocean
}

\author{
Ray G. Peterson and Lothar Stramma \\ Institut für Meereskunde an der Universität Kiel, Düsternbrooker Weg 20, 2300 Kiel 1, F.R.G.
}

\begin{abstract}
In this paper we present a literature survey of the South Atlantic's climate and its oceanic upper-layer circulation and meridional heat transport. The opening section deals with climate and is focused upon those elements having greatest oceanic relevance, i.e., distributions of atmospheric sea level pressure, the wind fields they produce, and the net surface energy fluxes. The various geostrophic currents comprising the upper-level general circulation are then reviewed in a manner organized around the subtropical gyre, beginning off southern Africa with the Agulhas Current Retroflection and then progressing to the Benguela Current, the equatorial current system and circulation in the Angola Basin, the large-scale variability and interannual warmings at low latitudes, the Brazil Current, the South Atlantic Current, and finally to the Antarctic Circumpolar Current system in which the Falkland (Malvinas) Current is included. A summary of estimates of the meridional heat transport at various latitudes in the South Atlantic ends the survey.
\end{abstract}

\section{CONTENTS}

1. Introduction 2

2. Climatic Elements 2

3. Subtropical and Equatorial Circulation 11

3.1. Agulhas Current Retroflection 11

3.2. Benguela Current 16

$\begin{array}{ll}\text { 3.3. Equatorial Currents } & 18\end{array}$

3.3.1. Components of the system 18

3.3.2. Angola Basin circulation 26

3.3.3. Large-scale variability and interannual warmings $\quad 29$

$\begin{array}{ll}\text { 3.4. Brazil Current } & 33\end{array}$

3.5. South Atlantic Current $\quad 39$

3.5.1. Subtropical Front 40

3.5.2. Geostrophic flow 41

4. Antarctic Circumpolar Current 42

4.1. Zonation $\quad 42$

4.2. Volume transport $\quad 51$

5. Meridional Heat Transport $\quad 59$

$\begin{array}{ll}\text { 6. Outlook } & 61\end{array}$

7. Acknowledgements $\quad 62$

8. References 63 


\section{INTRODUCTION}

The circulation patterns and diversity of water masses in the South Atlantic Ocean are extraordinary in many important respects, as the early results of the Meteor expedition of the 1920s clearly demonstrated (Wüst, 1935; DEFANT, 1936). Since then, the South Atlantic has been the subject of increasing levels of scientific interest and research, especially of late, from which substantial amounts of new knowledge have come. This is particularly true for the near-surface, wind-driven circulation which is much better understood than its deep, thermohaline-driven counterpart. Presently, as there has been much learned about the South Atlantic's upper-level currents in recent years, it seems timely that the published observations concerning them be drawn together into a single picture. Although the available information is still far less than what is needed for a complete, detailed picture, it is nonetheless adequate for assembling a reasonably coherent overview. The purpose of this paper, for the region of the Atlantic extending from the South Equatorial Current to the Antarctic Circumpolar Current, is to provide such an overview.

The large-scale, upper-level geostrophic circulation in the South Atlantic Ocean is schematically depicted in Fig.1. This figure is intended to serve as a reference for the following discussions. The same holds true of Fig. 2 , which shows the major bathymetric and other physical features of the South Atlantic. Referring back to Fig. 1, the upper-level circulation is dominated by a system of gyres and by the equatorial and circumpolar current systems. Being that these major systems are all wind-driven, we start by considering a few of the basic climatological elements of the South Atlantic. Next come descriptions of the upper-level circulation beginning with the Agulhas Current Retroflection and progressing anti-clockwise around the basin to the Antarctic Circumpolar Current. We then summarize the meridional heat transport in the South Atlantic and conclude with a brief outlook for further studies.

\section{CLIMATIC ELEMENTS}

All weather observations made at sea from the year 1961 and later have been collected and evaluated by eight nations, with each being responsible for a particular ocean area (WMO, 1963; 1977). Observations from the South Atlantic are handled by the Federal Republic of Germany, and these have been used by HöFlcH (1984) to construct a climatology for this ocean. His is the chief source of information for this section, with the exception of wind stress fields which are obtained from other sources.

Shown in Fig. 3 are the climatic averages of atmospheric sea level pressure for the months of January and July. As can be inferred, the climate of much of the South Atlantic Ocean is dominated by a semi-permanent high pressure system in the subtropics, one that is similar to those found over other ocean basins. In the southern summer, the South Atlantic subtropical high is centered near $32^{\circ} \mathrm{S} 5^{\circ} \mathrm{W}$ with a central pressure of just over $1021 \mathrm{mbar}(1 \mathrm{mbar}=100 \mathrm{~Pa})$. In winter, the center of this high increases in pressure to about $1025 \mathrm{mbar}$ and moves some $800 \mathrm{~km}$ toward the northwest, to approximately $27^{\circ} \mathrm{S} 10^{\circ} \mathrm{W}$. Although the central pressure is highest in southern winter, the pressure differences between the center of the high and the coast lines of South America and southern Africa are greater in summer, which are direct results of the thermal lows which develop over each continent during summer. Consequently, the along-shore winds off the west coast of southern Africa and the associated upwellings are stronger in summer. And because the center of the high resides over the eastern basin of the South Atlantic, the trade winds near southern Africa are generally stronger than those near Brazil. Farther south, in the mid- and highlatitudes, the isobars are nearly zonal in the mean for each month, producing the westerly winds which extend southward to the circumpolar belt of low pressure centered near $65^{\circ} \mathrm{S}$. 


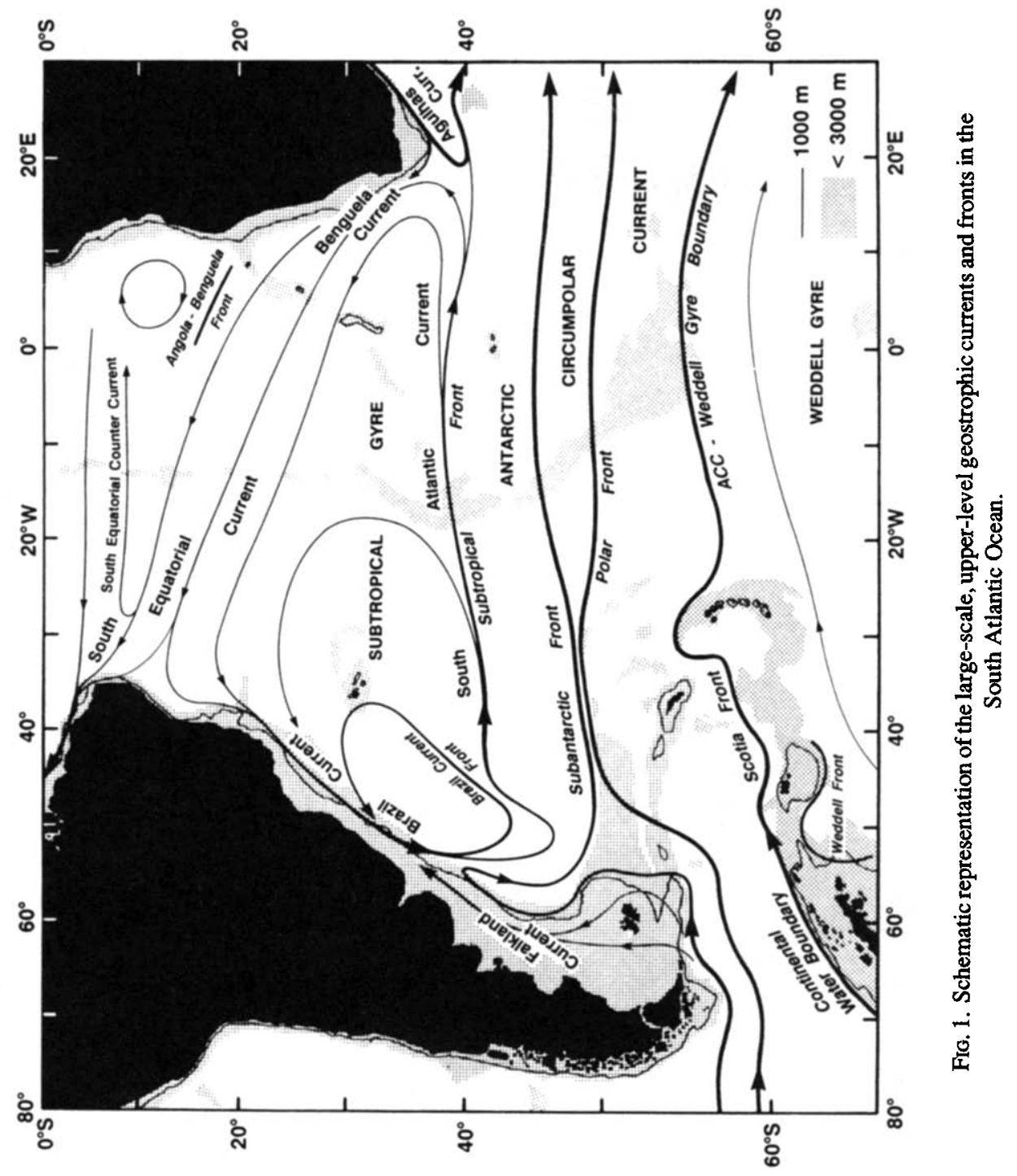




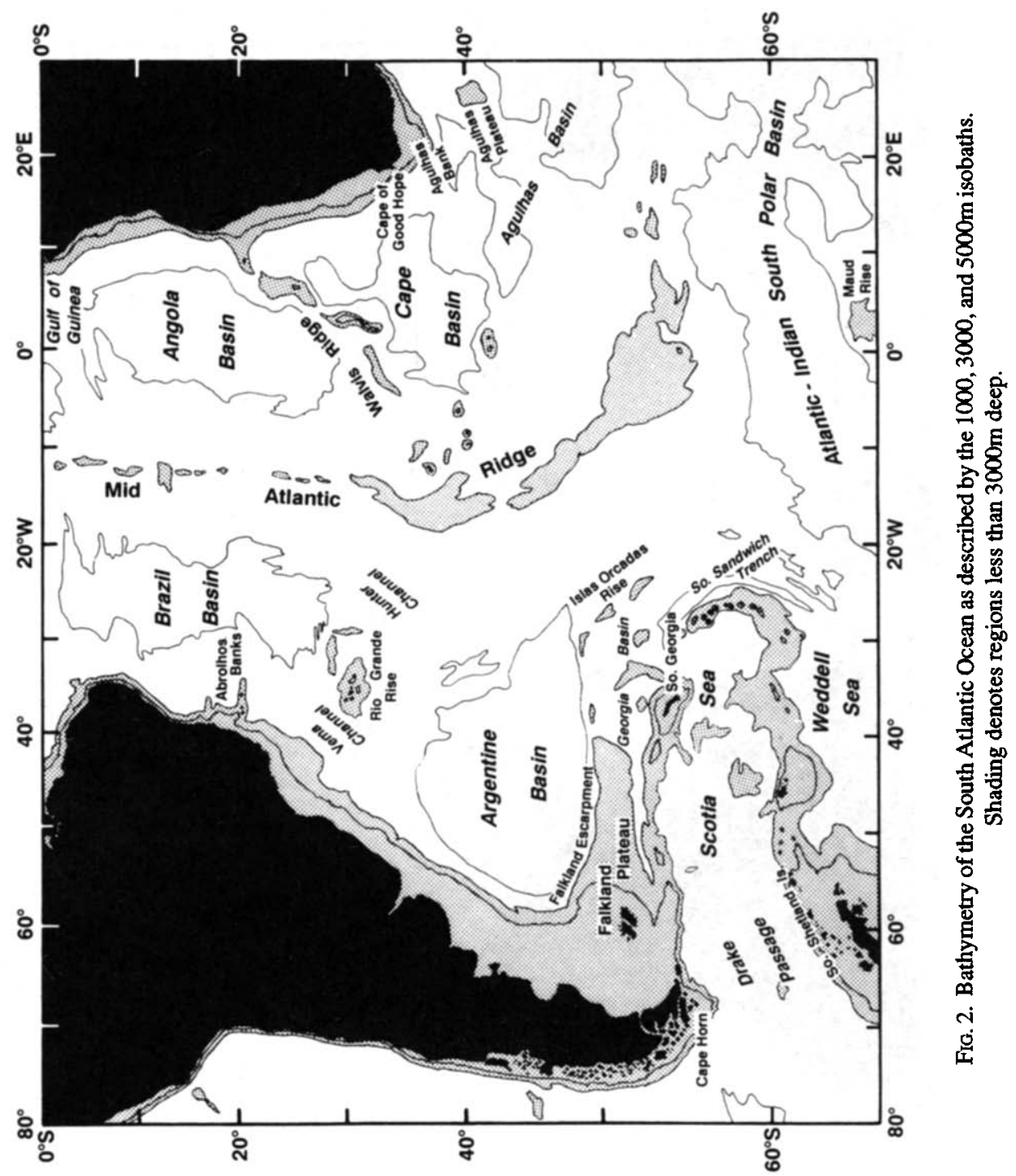




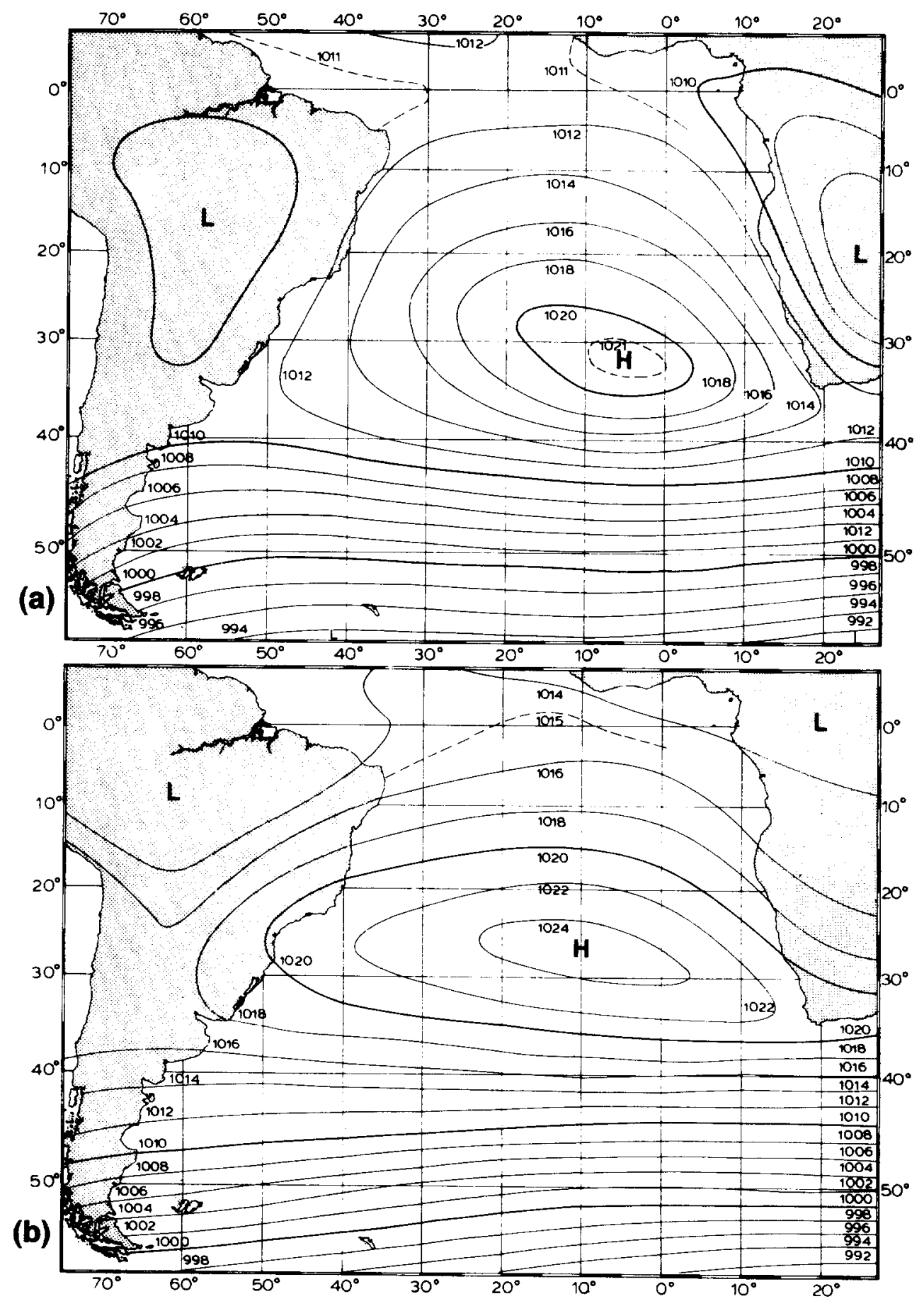

Fig. 3. Mean atmospheric sea level pressure (mbar) for (a) January, and (b) July (adapted from HOFLICH, 1984). 
The surface wind patterns during January and July over the South Atlantic are shown in Fig.4 with wind roses in $10^{\circ}$ squares. Clearly seen is a relative steadiness in each season, in both direction and speed, of the trade winds near Africa and in the tropics. Most observations from those regions, by far, are of winds weaker than Beaufort force 5 (less than $11 \mathrm{~m} \mathrm{~s}^{-1}$ ). In contrast, there is much greater variability in the higher latitudes where westerly winds prevail, in both speed and direction, owing to the eastward translation of troughs of low pressure extending northward from the subpolar lows. Within this band of westerly winds, the highest velocities are found generally to the south and southwest of Africa, which is illustrated by the annual averages of surface wind stress components in Fig.5. The highest values in the South Atlantic, greater than $0.2 \mathrm{~Pa}$, occur near $45^{\circ} \mathrm{S} 15^{\circ} \mathrm{E}$. These result from the compression of isobars between the high pressure ridge lying over the warm Agulhas Current (Fig.3) and the subpolar low pressure belt displaced north by the zonal asymmetry of Antarctica east of the Weddell Sea. This compression of isobars also leads to the greatest values of wind stress curl in the annual mean, both positive and negative, to occur south and southwest of Africa (Fig.6) with absolute values in each regime exceeding $2 \times 10^{-7} \mathrm{~Pa} \mathrm{~m}^{-1}$.

The climatology of HAN and LEE (1981) was used to produce the annual-mean field of wind stress curl in Fig.6 (S. PATterson, personal communication, 1985), and it shows a line of zero curl extending from the southern tip of Africa to just north of the eastern promontory of Brazil. The orientation of this line corresponds well with the separation of the Benguela Current from the southern end of Africa and with its northwestward extension into the South Equatorial Current (Fig.1). North of the line are weakly negative values of wind stress curl, which are consistent with there being a weak cyclonic gyre in the Angola Basin. The poleward limit to the subtropical gyre, however, does not coincide with a line of zero wind curl; instead, the Subtropical Front better corresponds in position with a maximum in curl oriented zonally across the basin near $40^{\circ} \mathrm{S}$, close to which should be a maximum in Ekman-layer convergence. But just how accurately we know the distributions of wind stress curl in the South Atlantic is questionable to say the least. The HELLERMAN and RoSENSTEIN (1983) wind stress climatology was used by GoRDON and BosLEY (1990) to present another field of the annually-averaged curl of wind stress, and in their field a zonal maximum lies closer to $30^{\circ} \mathrm{S}$ in the central portions of the basin. This disparity in the position of the wind curl ridge is the most obvious difference between the two climatologies, and is likely a result of the poor density of atmospheric measurements from regions south of the major shipping lanes. The same problem exists with the interpretation of the line of zero wind curl extending zonally across the basin at latitudes of roughly $45^{\circ}-50^{\circ} \mathrm{S}$. In the central and eastern South Atlantic it corresponds rather well with the position of the Subantarctic Front, which is poorly-understood in terms of the dynamics responsible for it. Near the western boundary though, in a region of complex bottom topography and flow patterns, there is little correlation between the positions of these two features.

The fluxes of heat energy across the air-sea interface are strongly dependant upon season, as is shown in Fig.7. Depicted in this figure are fields of net oceanic heat gain in January and July due to the combined fluxes of sensible, latent, and radiative energy. Dominating these fields are the latent and radiational fluxes, which for the most part are opposed in direction owing to strong evaporation over the tropical and subtropical regions. Sensible heat exchanges are normally of secondary importance. During the southern summer, the greatest heat gain $\left(>200 \mathrm{~W} \mathrm{~m}^{-2}\right)$ occurs in the region of cool, upwelled water off the western coast of southern Africa. Though the alongshore winds and evaporation in that region are strongest then, sparse cloudiness and high solar elevation have prevailing effects. Large heat gains also exist in the cool regions of the Falkland Current and the Antarctic Circumpolar Current. The only region of heat loss $\left(\sim 50 \mathrm{~W} \mathrm{~m}^{-2}\right)$ found south of the equator during summer, as a consequence of strong evaporation, is near the warm Agulhas Current. 

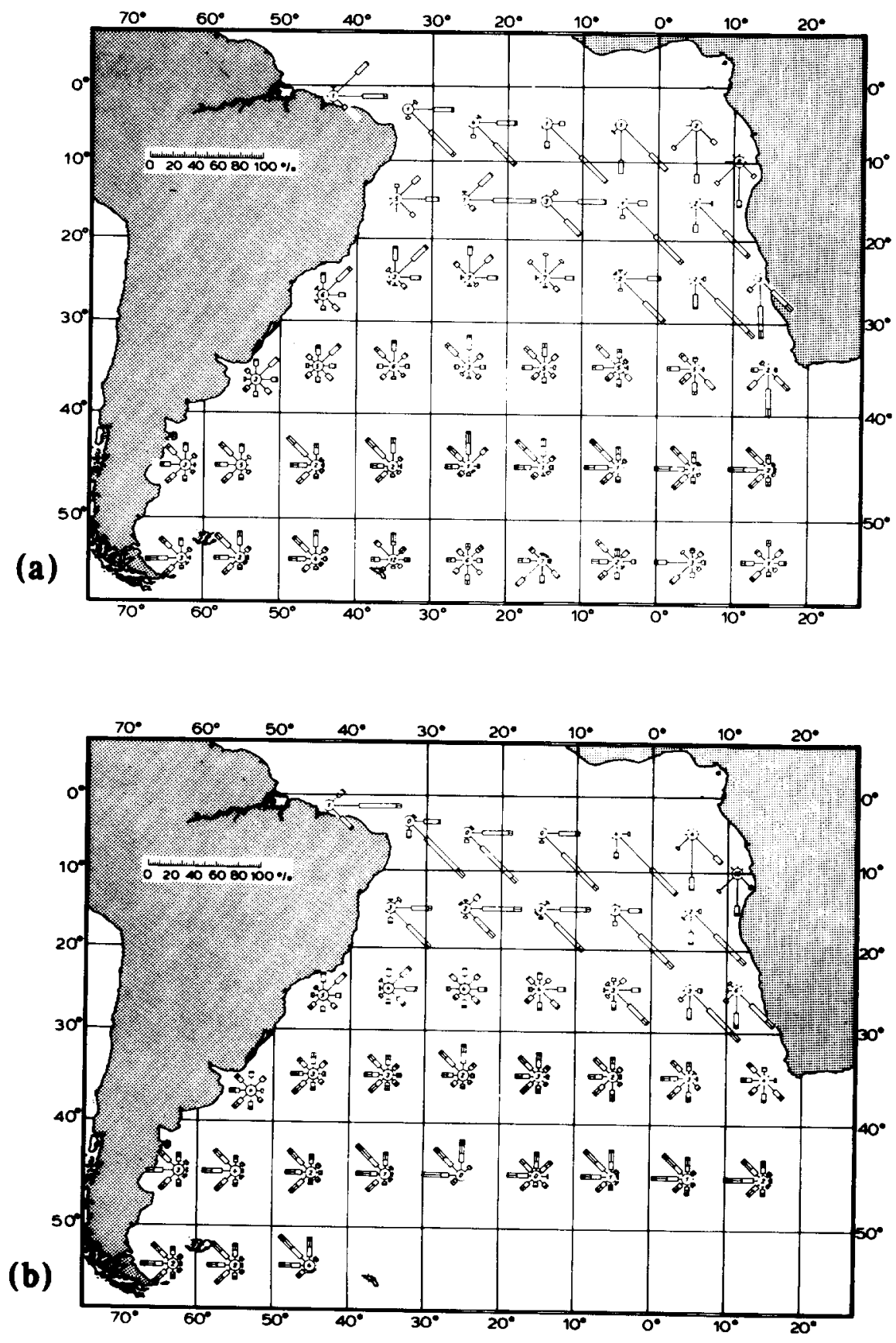

Fig. 4. Wind roses for $10^{\circ}$ squares for (a) January, and (b) July (HoF.ICH, 1984). Lengths of the arms indicate the mean relative frequencies (according to the scale in upper left) of eight wind directions divided into four groups of wind force. From the center outward they are Beaufort 1-3 (0.5-5.5m s$\left.{ }^{1}\right), 4-5\left(5.5-11 \mathrm{~m} \mathrm{~s}^{-1}\right), 6-7\left(11-17 \mathrm{~m} \mathrm{~s}^{-1}\right)$, and $>8\left(>17 \mathrm{~m} \mathrm{~s}^{-1}\right)$. Numbers within the circles are percent occurrences of calm or light and variable winds. 

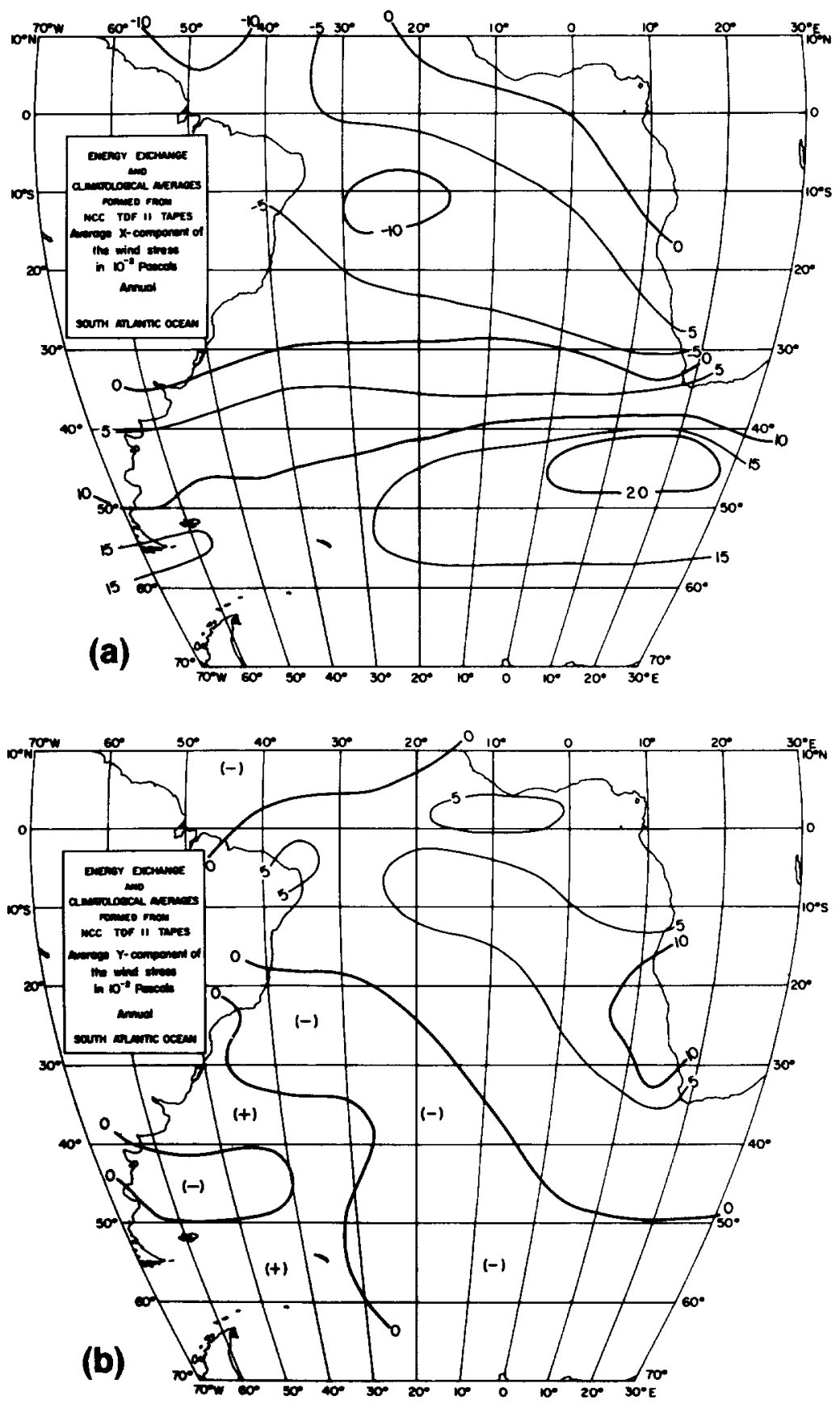

FIG. 5. Annual averages of (a) $x$-component and (b) $y$-component of wind stress $\left(10^{-2} \mathrm{~Pa}\right.$; BUNKER, 1988). 


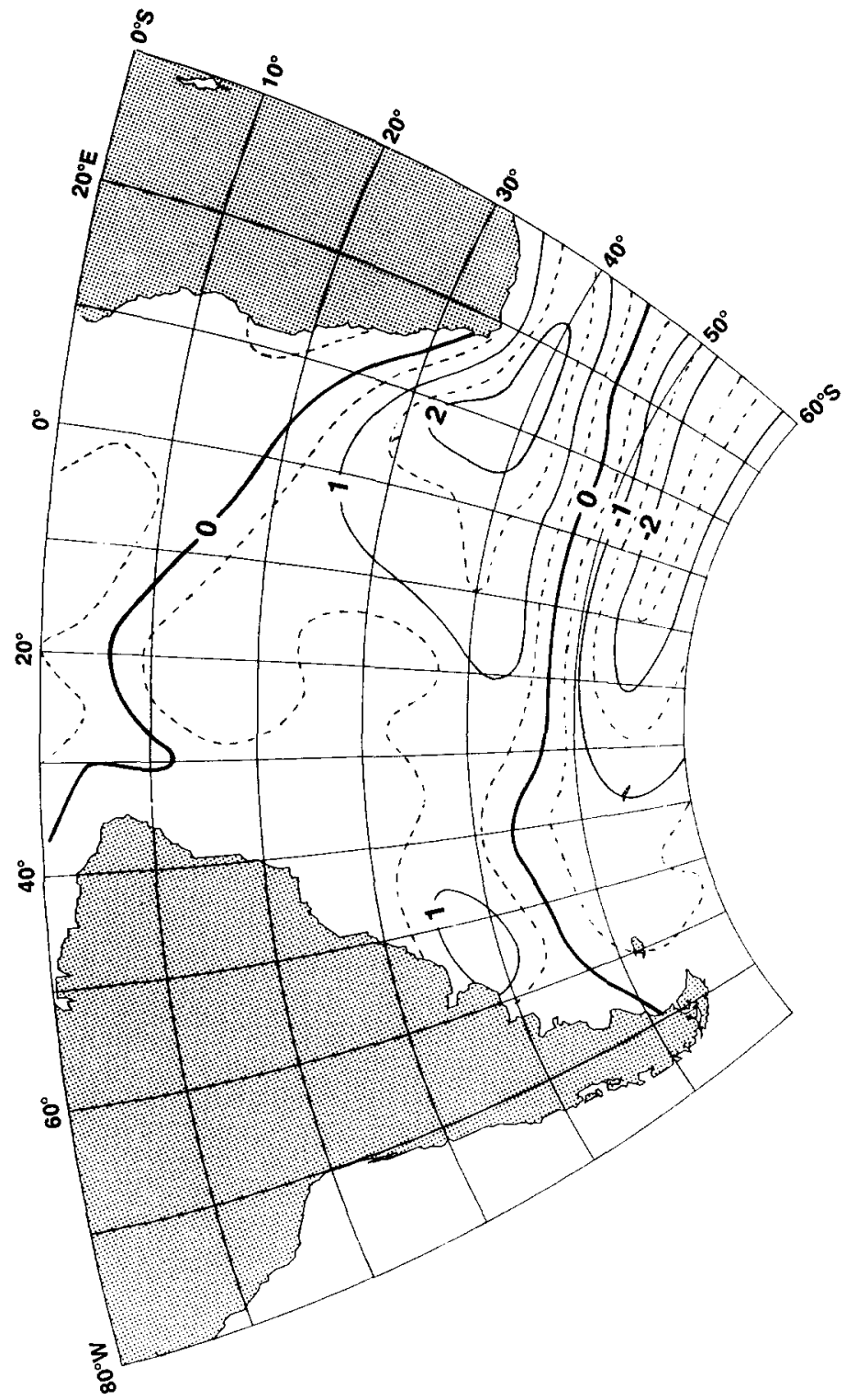

总 

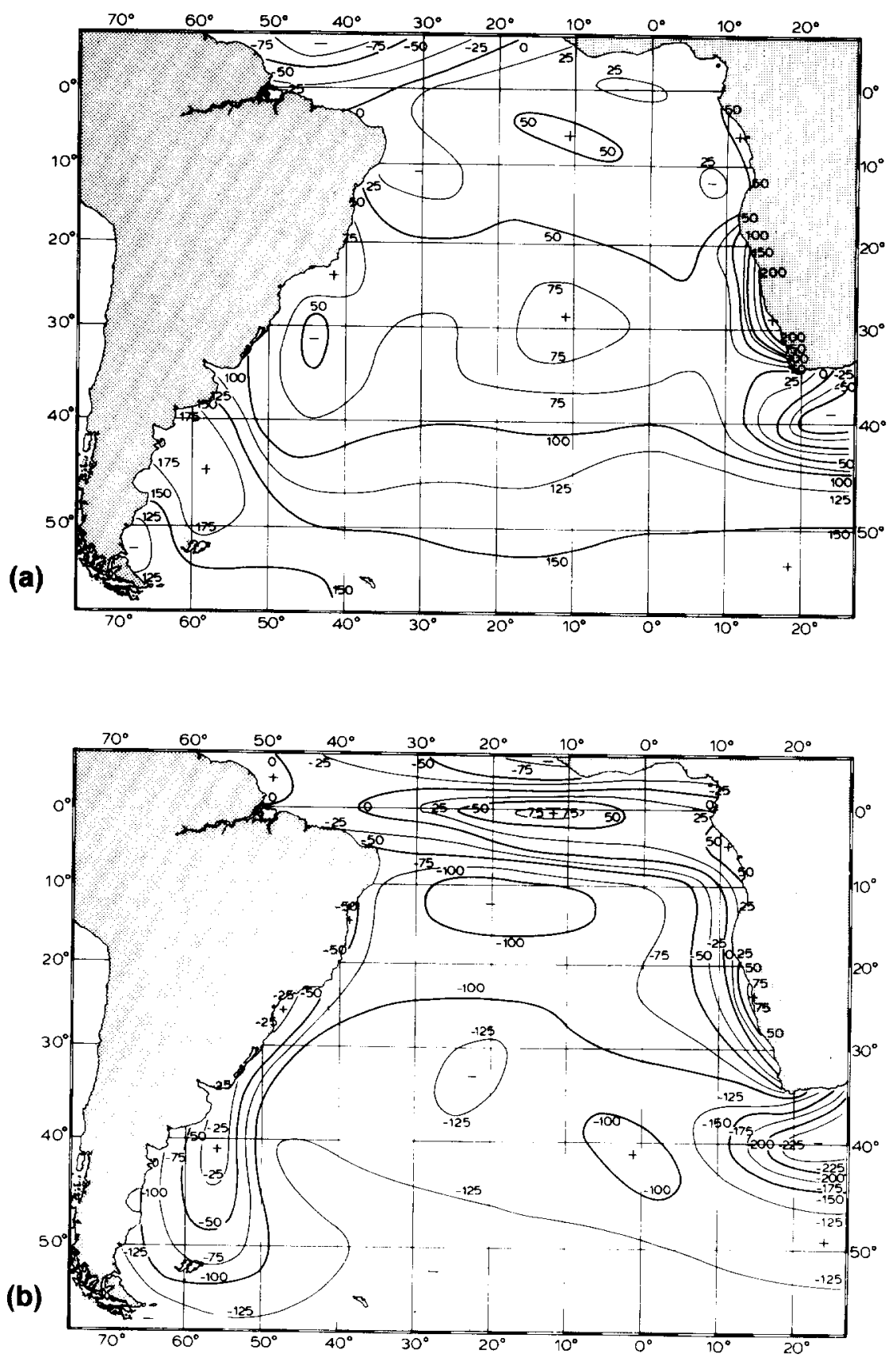

Fig. 7. Net heat gain by the sea ( $\mathrm{W} \mathrm{m}^{-2}$ ) for (a) January, and (b) July (HÖFLICH, 1984). 
The highest sea surface temperatures in the Atlantic are found at the position of the atmospheric intertropical convergence zone (HöFLICH, 1974; LAMB, 1977), a zone which moves from just north of the equator in January to some $10^{\circ}-15^{\circ}$ farther north in July. As a result of much reduced cloudiness in July, combined with an upwelling of cool water which acts to reduce the flux of latent heat, the equatorial region experiences heat gains approaching $100 \mathrm{~W} \mathrm{~m}^{-2}$ (Fig. $7 \mathrm{~b}$ ). Heat gains of nearly this magnitude also occur in the upwelling region inshore of the Benguela Current, and although the contours suggest a continuity between these two regimes, they are in fact separate features. Of greater magnitudes during the southern winter though, are the heat losses in regions of strong evaporation, which are supplemented by losses of sensible heat on the order of $50 \mathrm{~W} \mathrm{~m}$ 2 in the southern Antarctic Circumpolar Current and $30 \mathrm{~W} \mathrm{~m}^{-2}$ off southern Africa and on the Patagonian shelf. The most notable net energy fluxes during southern winter are the values approaching $-250 \mathrm{~W} \mathrm{~m}^{-2}$ in the Agulhas Current region south of Africa where strong and cold winds blow over warm, subtropical water. Large heat losses resulting primarily from evaporation also occur over much of the central South Atlantic during winter when the sea surface is warmer than the overlying air. In the Falkland Current region, the air-sea temperature difference tends toward zero and the fluxes of sensible and latent heat are minimized. These combine with a northsouth gradient in the radiation balance to produce relatively weak fluxes of about $-25 \mathrm{~W} \mathrm{~m} \mathrm{~m}^{-2}$ near $40^{\circ} \mathrm{S} 57^{\circ} \mathrm{W}$ (Fig. 7 b).

\section{SUBTROPICAL AND EQUATORIAL CIRCULATION}

In this section we give an overview of the various upper-level currents comprising the South Atlantic subtropical gyre and those equatorward. A convenient starting point is the Agulhas Current Retroflection off southern Africa. Although it occupies just a small fraction of the South Atlantic, the Agulhas Retroflection is nonetheless important for the inter-ocean exchanges of water masses taking place there. We then proceed to the Benguela Current, the equatorial currents and circulation in the Angola Basin, the large-scale and interannual variability in the lower latitudes, and then around the rest of the subtropical gyre with the Brazil and South Atlantic currents.

\subsection{Agulhas Current Retroflection}

The Agulhas Current is the western boundary current of the southernmost of two cells comprising the subtropical gyre in the Indian Ocean (WYRTKI, 1971; GoRDON, LUTJEHARMS and GRÜNDLINGH, 1987), a current lying along the southeastern continental shelf of Africa where it is dynamically similar to its Gulf Stream and Kuroshio Current counterparts (DIETRICH, 1936; PEARCE, 1977). The southern Agulhas Current flows southwestward as a narrow jet along a steep continental slope and is normally pinned to within $10-15 \mathrm{~km}$ of its mean position at latitudes of $28.5^{\circ}-34^{\circ} \mathrm{S}$ (GRÜNDLNGH, 1983). Large meanders can sometimes occur within this region (PEARCE, 1977), which according to satellite observations are solitary events (the "Natal pulse") extending an average of $170 \mathrm{~km}$ offshore with downstream propagation rates of approximately $21 \mathrm{~cm} \mathrm{~s}^{-1}$; these rates decrease downstream to $5 \mathrm{~cm} \mathrm{~s}^{-1}$ as the continental shelf broadens near $34^{\circ} \mathrm{S}$ (LUTJEHARMS and RoBERTs, 1988). The current then separates from the coast and continues southwestward along the Agulhas Bank (see Fig. 8 for a schematic representation) where numerous meanders, plumes and eddies exist (LutJeharms, Catzel and Valentine, 1989). The growth rate of the Agulhas Current from Durban $\left(30^{\circ} \mathrm{S}\right)$ to the middle Agulhas Bank has been estimated from quasi-synoptic data by GoRDON, LUTJEHARMS and GRÜNDLINGH (1987) as being 
2.7Sv per $100 \mathrm{~km}\left(1 \mathrm{sverdrup}=10^{6} \mathrm{~m}^{3} \mathrm{~s}^{-1}\right)$, less than half the $6 \mathrm{~Sv}$ per $100 \mathrm{~km}$ obtained by GRÜNDLINGH (1980) from historical data between Port Edward $\left(32^{\circ} \mathrm{S}\right)$ and the southern Agulhas Bank. The maximum volume transport of the current is attained in the vicinity of the Agulhas Bank, where depth-integrated values relative to the bottom are in the range of 95Sv (GORDON, LUTJEHARMS and GRÜNDLINGH, 1987) to 136 Sv (JACOBS and GEORGI, 1977). These values are significantly higher than the 40-60Sv obtained by applying the Sverdrup relation to the curl of wind stress along $32^{\circ} \mathrm{S}$ in the Indian Ocean (Fig.10 and Table 3 in HeLlerman and RosenstenN, 1983), leading Gordon, LUTJEHARMS and GRÜNDLINGH (1987) to conclude that the Agulhas Current experiences significant enhancement within a recirculation cell.

For the region off Durban ( $\left.30^{\circ} \mathrm{S}\right)$, PEARCE (1977) defined the core of the Agulhas Current to be where surface velocities exceed $100 \mathrm{~cm} \mathrm{~s}^{-1}$. On the basis of directly-measured upper-ocean velocity profiles, he found the current core on average to be $34 \mathrm{~km}$ wide with a mean peak speed of $136 \mathrm{~cm} \mathrm{~s}^{-1}$; the greatest individual peak speed was $245 \mathrm{~cm} \mathrm{~s}^{-1}$, in good agreement with maximum velocities of $250 \mathrm{~cm} \mathrm{~s}^{-1}$ indicated by ship drifts (BARLow, 1931) and $260 \mathrm{~cm} \mathrm{~s}^{-1}$ by satellite-tracked drifting buoys (GRÜNDLINGH, 1977; 1978). A directly-measured surface velocity in excess of $200 \mathrm{~cm} \mathrm{~s}^{-1}$ was also obtained by GRüNDLINGH (1980, his Fig. 2) off Port Edward $\left(\sim 31.5^{\circ} \mathrm{S}\right)$. Speeds of this magnitude, though, have not been observed with geostrophic shears alone; relative to $1500 \mathrm{dbar}$ on the eastern side of the Agulhas Bank near $36^{\circ} \mathrm{S}$ (where the peak speeds are expected to be less than farther north because of the southward broadening of the current), GoRDON, LUTJEHARMS and GRÜNDLINGH (1987) obtained their greatest geostrophic surface speed of $110 \mathrm{~cm}$ $\mathrm{s}^{-1}$. Observations from an array of current meters moored south of Africa for a two-year period showed velocities off the Agulhas Bank at depths of $200 \mathrm{~m}$ and more of $80-100 \mathrm{~cm} \mathrm{~s}^{-1}$, with most of the variability occurring in the period band of 80-120 days (LUYTEN, 1988). Although these current meter records revealed significant variability at the longest periods resolved, historical data have yet to show any clear seasonality in this poleward flow (PEARCE and GRÜNDLINGH, 1982).

Near $36^{\circ} \mathrm{S}$ the Agulhas Current leaves the continental shelf, develops oscillations of increasing amplitude (HARRIs and BANG, 1974), and usually in the region of $16^{\circ}-20^{\circ} \mathrm{E}$ retroflects back toward the Indian Ocean (LUTJEHARMS and VAN BALLEGOOYEN, 1988) as the Agulhas Return Current. The retroflection loop encloses a pool of Indian Ocean surface water south of Africa whose temperature is more than $5^{\circ} \mathrm{C}$ warmer than South Atlantic surface water at similar latitude (GORDON, 1985), but the loop has on one occasion been observed to contain a cold-core eddy which transported 64Sv of water (relative to $2400 \mathrm{dbar}$ ) in a direction opposed to that of the surrounding anticyclonic ridge (BENNETT, 1988). Downstream of the retroflection, bathymetry in the vicinity of the Agulhas Plateau produces an equatorward topographic Rossby wave in the return flow, which has been observed with hydrographic and XBT (expendable bathythermograph) data (BANG, 1970; DARBYShire, 1972; HARris and VAN Foreest, 1978; Gordon, LuTJeHARMS and GRÜNDLINGH, 1987), in satellite infrared (IR) images (HARRIS, LEGECKIS and VAN FOREEST, 1978; LUTJEHARMS, 1981; LUTJEHARMS and VAN BALLEGOOYEN, 1988), and in the trajectories of satellitetracked drifting buoys (GrüNDLINGH, 1978; Fig.6d in HofMANN, 1985). Infrequently, the core of the Agulhas Return Current can pass over the Agulhas Plateau (BENNETT, 1988).

The Agulhas Current is highly baroclinic, as more than four-fifths of its transport occurs in the upper 1000m (DuNCAN, 1970). Consistent with the high baroclinicity are water mass distributions showing Indian Ocean water to be restricted to the upper 1500-2000m of the retroflection, beneath which are waters from the Atlantic and Southern Oceans (GORDON, LUTJEHARMS and GRÜNDLINGH, 1987; BENNETT, 1988). But not all of the Indian Ocean water carried into the retroflection turns back with the Agulhas Return Current (RENNELL, 1832; DIETRICH, 1935; TAFT, 1963; SHANNON, 1966; BANG, 1973); a small portion of it leaks into the Atlantic. It is not known how much of this leakage 


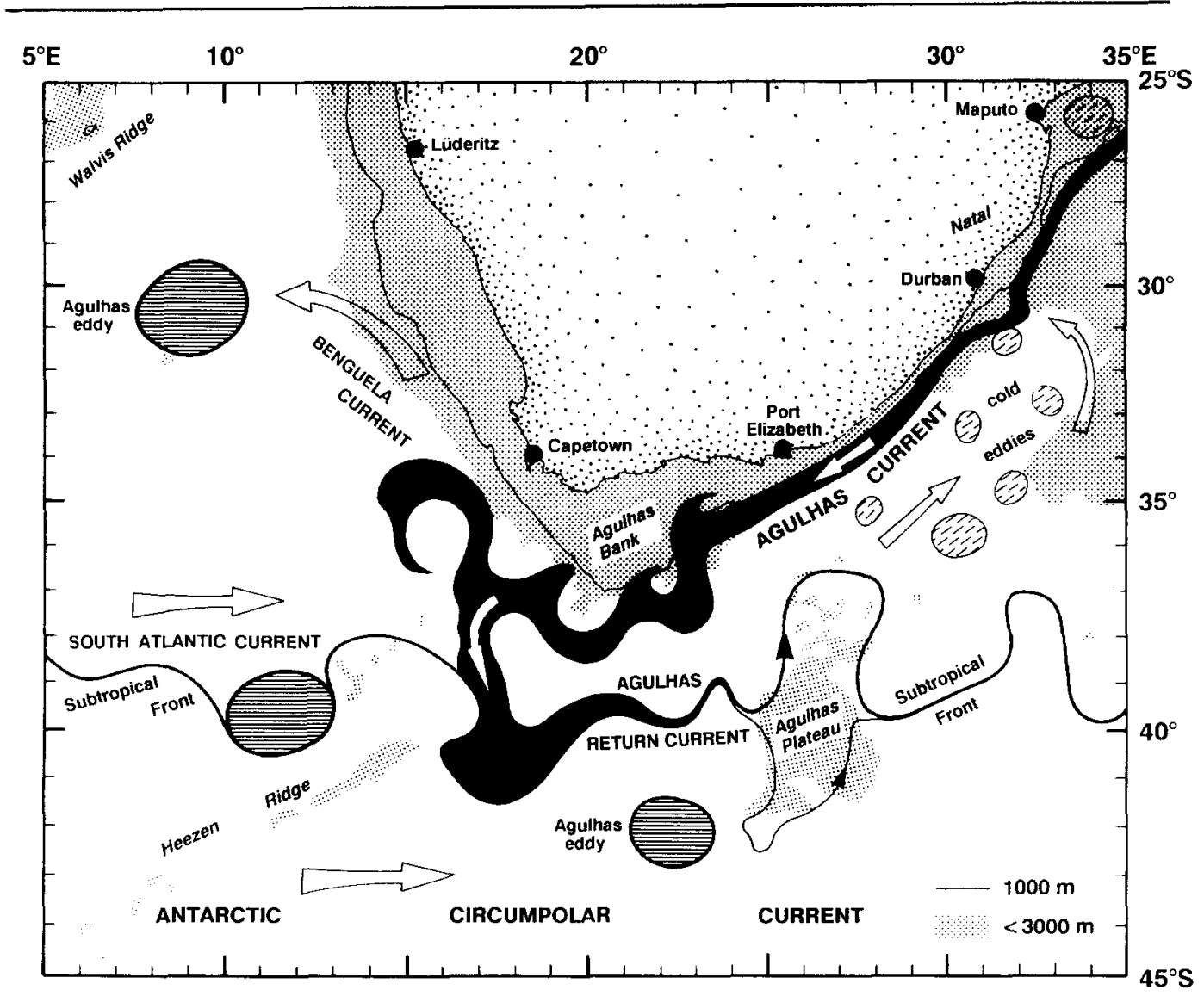

FIG. 8. Schematic representation of the Agulhas Current system (adapted from LUTJEHARMS and VAN BALLEGOOYEN, 1988 and LUTJEHARMS, 1989). Open arrows indicate the general direction of the surface geostrophic currents.

occurs on a continuous basis, but according to satellite IR images there are times, apparently not common, when an unbroken extension of the Agulhas Current can round the southern end of Africa and directly feed Indian Ocean water into the Benguela Current (SHANNON, LUTJEHARMS and AGENBAG, 1989). Estimates for the rate of this interocean transfer in the upper $1500 \mathrm{~m}$ or less range from 3 to $14 \mathrm{~Sv}$ (Table 1), or a tenth or less of the total Agulhas Current transport. But all of these have been computed from data obtained on surveys crossing at least one Agulhas eddy. Most recently, Gordon and HAXBY (1990) have estimated that just the process of Agulhas eddies moving into the Atlantic can account for a time-averaged transfer of $10-15 \mathrm{~Sv}$ in the layer above the Antarctic Intermediate Water (nominally in the upper $1000 \mathrm{~m})$. GoRDON $(1985 ; 1986)$ has proposed that this transfer of warm and salty Indian Ocean water into the Atlantic is an important part of the global thermohaline circulation which must exist to balance the export of North Atlantic Deep Water from the Atlantic Ocean by way of the Antarctic Circumpolar Current. Results from an inverse calculation, however, suggest that a large net transfer according to this "warm water route" hypothesis is inconsistent with the known circulation and that the "cold water route" (northward flow of intermediate and bottom waters from the Antarctic) forms the more important closure to the meridional thermohaline circulation (RINTouL, 1990).

Within the region just south of Africa are levels of eddy kinetic energy, as estimated from 
TABLE 1. Estimates of transfer of Indian Ocean water to the Atlantic from the Agulhas Current Retroflection

\begin{tabular}{|c|c|c|c|c|}
\hline Author & Data & Reference & $\begin{array}{l}\text { Transfer } \\
\left(10^{6} \mathrm{~m}^{3} \mathrm{~s}^{-1}\right)\end{array}$ & Remarks \\
\hline $\begin{array}{l}\text { HARRIS and VAN FORERST } \\
\text { (1978) }\end{array}$ & Africana II, Mar 1969 & $1000 \mathrm{dbar}$ & 5 & estimate uncertain \\
\hline GORDON (1985) & Knorr, Nov-Dec 1983 & $1500 \mathrm{dbar}$ & 15 & \\
\hline $\begin{array}{l}\text { GORDON, LUTJEHARMS and } \\
\text { GRUNDLINGH (1987) }\end{array}$ & Knorr, Nov-Dec 1983 & $1500 \mathrm{dbar}$ & 10 & \\
\hline BENNETT (1988) & $\begin{array}{l}\text { Knorr, Nov-Dec } 1983 \\
\text { Knorr, Jan-Feb } 1984 \\
\text { Washington, Feb-Mar } 1985\end{array}$ & $\begin{array}{l}1500 \mathrm{dbar} \\
1500 \mathrm{dbar} \\
1500 \mathrm{dbar}\end{array}$ & $\begin{array}{l}6.3 \\
9.6 \\
2.8\end{array}$ & $\begin{array}{l}<9^{\circ} \mathrm{C}(300-800 \mathrm{dbar}) \\
" \\
"\end{array}$ \\
\hline $\begin{array}{l}\text { STRAMMA and PETERSON } \\
\text { (1990) }\end{array}$ & Knorr, Nov 1983 & $\sim 3500 \mathrm{~m}$ & 8 & in the upper $1000 \mathrm{~m}$ \\
\hline GORDON and HAXBY (1990) & Geosat altimeter census & - & $10-15^{*}$ & above the AAIW \\
\hline
\end{tabular}

- Time-averaged rate, due only to the migration of Agulhas eddies into the South Atlantic

${ }^{b}$ Antarctic Intermediate Water $(\sim 800 \mathrm{~m}$ depth)

drifter trajectories, which are higher than anywhere else in the southern hemisphere. Depending on the computational method used, these eddy energies range from approximately $1000 \mathrm{~cm}^{2} \mathrm{~s}^{-2}$ (JoHnson, 1989) to $4000 \mathrm{~cm}^{2} \mathrm{~s}^{-1}$ (PATTerson, 1985). Using a global data set of ship drift observations, WyRTKI, MAGAARD and HAGER (1976) found the eddy energies in the Agulhas Retroflection region to be comparable to eddy energies in western boundary current regimes of the northern hemisphere. Seasat altimetry gives similar results (Cheney, MaRSH and BeCKLEY, 1983). Contributing to this region's high eddy kinetic energies, according to satellite IR images (LUTJEHARMs and VAN BALLEGOOYEN, 1988), are an average of nine penetrations per year of the Agulhas Retroflection into the Atlantic, each followed by the shedding of an eddy; the newly-shed eddies average $320 \mathrm{~km}$ in diameter and drift away toward the west at about $12 \mathrm{~cm} \mathrm{~s}^{-1}$. Altimeter observations from GEOSAT, however, reveal a slower production rate of Agulhas eddies, only about 5 per year, and a slower mean drift of $5-8 \mathrm{~cm} \mathrm{~s}^{-1}$ toward the northwest once they have crossed the Walvis Ridge (GoRDON and HAXBY, 1990). A sea-going survey has recently documented the actual shedding of one of these eddies from the retroflection loop (LUTJEHARMS and GORDON, 1987). The transport around that eddy was 40Sv, while an older Agulhas eddy farther to the northwest carried 35Sv (GORDON, LUTJEHARMS and GRÜNDLINGH, 1987). Depending on radial distance from the center, surface speeds around Agulhas eddies range from 20 to $80 \mathrm{~cm} \mathrm{~s}^{-1}$ (OLson and Evans, 1986). The sea surface at the crest of one such eddy stood $30-40 \mathrm{~cm}$ above that of the general surroundings (GoRDON and HAXBY, 1990).

The eventual fate of Agulhas eddies is only now coming to light. Using thermocline topography combined with a 2-layer diagnostic model, OLson and Evans (1986) concluded that Agulhas eddies are among the most energetic in the world and should have lifetimes of 5-10 years with potential importance to the structure of the South Atlantic subtropical gyre. MCCARTNEY and 
WOODGATE-JONES (1990) detected an anticyclonic eddy in a hydrographic section near the eastern side of the mid-Atlantic ridge at $5^{\circ} \mathrm{W} 23^{\circ} \mathrm{S}$, and surmised that it had most probably separated from the Agulhas Retroflection two winters earlier and had subsequently advected along with the largescale circulation of the subtropical gyre. GEOSAT altimeter data are confirming that this can happen, and are providing evidence that Agulhas eddies can remain intact all the way across the South Atlantic to the region of the Brazil Current (GoRDON and HAXBY, 1990). It appears that most Agulhas eddies find their way into the South Atlantic subtropical gyre, but some of them can migrate south into the Antarctic Circumpolar Current. The first indication for this was given by DEACON (1937, p.75) when he implied that an observation of subtropical water at a position normally south of the Subtropical Front was one of Agulhas Current water, but CLowes (1950) argued it to be an isolated patch of warm Atlantic water instead. A disruption of the Subtropical Front southwest of Cape Town in 1964 was reported by DunCAN (1968) as being the effect of an Agulhas eddy, one that also contained subtropical Atlantic water (Visser, 1969). Other warm eddies poleward of the Subtropical Front south of Africa have been observed (LUTJEHARMS and VALENTINE, 1988a, 1988b), with at least one being composed of Agulhas Current water (LUTJEHARMS, 1988).

Until recently, the dynamics controlling the Agulhas Current Retroflection have not received much attention. Using a two-layer, wind-driven analytic model of the World Ocean without bottom topography, VERONS (1973) concluded that if the curl of wind stress in the Indian Ocean were weaker, the Agulhas Current would be able to round southern Africa and supply large amounts of Indian Ocean water to the Atlantic. VERONIS (1978) then included thermal driving in his model and observed the retroflection to result from a surfacing of the thermocline on the western side of the Agulhas. Effects of bottom topography on the course of the current were first addressed by DARBYSHIRE (1972), and again by LuTJEHARMS and VAN BALLEGOOYEN (1984), both with an inertial jet model originally proposed for the Gulf Stream by WARREN (1963) and later modified by RoBINSON and NIIIER (1967). LUTJEHARMS and VAN BALLEGOOYEN (1984) deduced that high bottom velocities $\left(>5 \mathrm{~cm} \mathrm{~s}^{-1}\right)$ are required for the current to penetrate into the Atlantic and that the location of retroflection critically depends on volume transport. Using fixed surface and bottom velocities, but with different velocity profiles, they obtained paths in which no retroflection occurred with low transport and increasingly earlier retroflection with higher transport rates (their Fig.3c). But Ou and De RuIJTER (1986) questioned whether bottom topography is really the main steering mechanism of the retroflection in light of the persistent circulation pattern observed and there being no substantial topographic feature in the retroflection area. They formulated a reduced-gravity two-layer analytic model incorporating inertia (only in the upper layer) and a curved coastline and were able to reproduce the retroflection with roughly the right dimensions. They concluded that the current path is primarily controlled by volume transport (inertia) and the beta effect. They also saw that if the volume transport is reduced by just $10 \%$ the modelled current will continue around the continent without leaving the coast. DE RUIJTER and BoudRA (1985) and BOUDRA and DE RUIJTER (1986) further included temporal variability and friction in a wind-driven quasi-isopycnic numerical model (BLECK and BoudRA, 1981) to explain the retroflection in terms of a change in the vorticity balance as the current leaves the South African coast. BoudrA and Chassignet (1988) and Chassignet and Boudra (1988) used the same model with increased realism; the former finding an increased importance in the divergent component of flow in the retroflection, while the latter found the shape of Africa and the inertia and baroclinicity of the current to be of primary importance for eddy formation, though the roles of barotropic and baroclinic instabilities were unclear. The necessary conditions for each of these hydrodynamic instabilities are met by the observed density field (BENNETT, 1988). 
Although the models which have been used to study the Agulhas Current are often quite different from one another, an aspect which seems to recur is that a weak Agulhas Current would not retroflect, but would continue around southern Africa into the Atlantic. As Ou and DE RuIJTER (1986) put it, could it be that (a) the Agulhas Current never weakens sufficiently to go around the African continent, or (b) other dynamical constraints such as those imposed by large-scale circulation outside the immediate retroflection area prohibit this occurrence? It now appears, however, that this occurrence is not so completely prohibited. During 1986 there was an abnormal intrusion of Agulhas Current water into the southern Benguela Current that persisted for much of the year (Shannon, LutJeharms and Agenbag, 1989). This intrusion took the form of a nearly continuous stream of surface water (as shown by a satellite IR image in their Fig.1) from around the Cape of Good Hope to as far north as $31^{\circ} \mathrm{S}$. While this warm intrusion of Indian Ocean water was cut off in early December 1986 by the appearance of Subantarctic Surface Water from the south, it demonstrates that part of the Agulhas Current can at times round the continent's southern terminus as a continuous stream.

\subsection{Benguela Current}

The Benguela Current is the eastern boundary current of the South Atlantic subtropical gyre. VERONIS (1973) developed an analytic two-layer global model driven by wind, and remarked that eastern boundary currents are required for geostrophically balanced circulation and set the stage for the intense upwelling often observed. But he also attributed a different function to the Benguela Current; it exits at least in part because of the abrupt adjustment of the thermocline depth at the latitude where subtropical and denser waters meet, giving rise to a flow (almost a source flow) that can be sufficiently intense for inertial processes to be important, as in western boundary currents.

According to charts by Defant (1961), ReID, Nowlin and Patzert (1977), Fu (1981), TsuchiYa (1985), Rem (1989) and Stramma and Peterson (1989), the Benguela Current begins as a northward flow off the Cape of Good Hope before bending toward the northwest to separate from the African coast at around $30^{\circ} \mathrm{S}$ while widening rapidly (Fig.9). In addition to being fed primarily by the South Atlantic Current, the southern current band of the subtropical gyre (STRAMmA and Peterson, 1990), the Benguela Current can also receive Agulhas Current water as well as Subantarctic Surface Water, the latter coming from perturbations in the Subtropical Front (Shannon, LutJeharms and Agenbag, 1989). In terms of its vertical dimensions, the Benguela Current is modest; REID (1989) has shown southward geostrophic flow all along the southern coast of eastern Africa at 1500dbar (his Fig.20) and essentially no depth-integrated net flow within the Cape Basin (his Fig.43).

Atmospheric conditions in the Benguela Current region are strongly influenced by the semipermanent high pressure system over the subtropical South Atlantic and by a low pressure system that develops over southern Africa during the austral summer (Fig.3). The prevailing winds in the region are from the south and southeast (Fig.4), which in turn drive an offshore surface drift and coastal upwelling of cold, nutrient-rich water. This upwelling exists, with much spatial and temporal variability, all along the southwestern coast of Africa from Cape Point $\left(34.35^{\circ} \mathrm{S}\right)$ to Cape Frio $\left(18.4^{\circ} \mathrm{S}\right)$, supporting one of the world's richest fisheries (GrIFFrtHs, 1981). The main upwelling occurs along the southern portion of the coast during the southern summer and moves north during winter (JONES, 1971), but the maximum compression of atmospheric isobars along the coast occurs in spring, and with it comes the most vigorous upwelling (SCHELL, 1968). The sharpest fronts and most intense northward jets along the shelf-edge, however, may occur during summer. SHANNON (1966) and BANG (1973) have found that vestiges of Agulhas Current water are almost always present in the region offshore of the southern upwelling regime in summer, warm water 


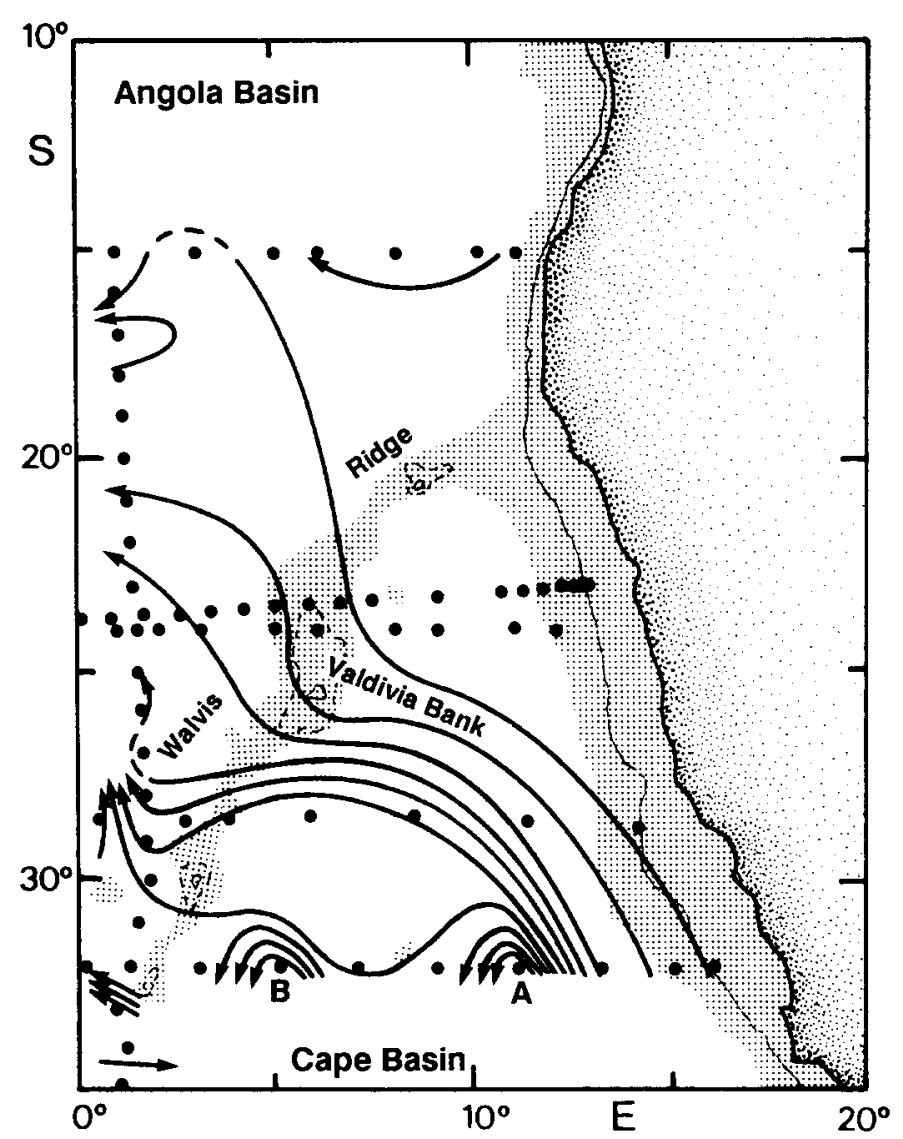

Fig. 9. Field of geostrophic transport of surface water (less dense than $\sigma_{0}=27.05 \mathrm{~kg} \mathrm{~m}^{-3}$, nominally in the upper $600 \mathrm{~m}$ ) relative to the $\sigma_{0}=27.75 \mathrm{~kg} \mathrm{~m}^{-3}$ isopycnal $(1700-2000 \mathrm{~m}$ depth) from STRAMMA and PETERSON (1989). Each flow line represents 3Sv. Also shown are the $1000 \mathrm{~m}$ isobath (light line), selected $2000 \mathrm{~m}$ isobaths (dashed lines), and areas less than $3000 \mathrm{~m}$ deep (shading).

are almost always present in the region offshore of the southern upwelling regime in summer, warm water which would act to intensify the frontal jet. Because of it being an important fisheries environment, the upwelling region around Cape Columbine $\left(33^{\circ} \mathrm{S}\right)$ and the frontal jet which develops there have received much study. As summarized by NELson and HuTCHINGs (1983), this northward jet lies over the steeply shelving 200-300m isobaths, has typical speeds in excess of $50 \mathrm{~cm} \mathrm{~s}^{-1}$, and is $20-30 \mathrm{~km}$ wide. Farther south, BANG and ANDREws (1974) obtained direct measurements of the current in the upwelling region near Cape Town $\left(34^{\circ} \mathrm{S}\right)$ in January 1973 and observed an intense frontal jet, of similar dimensions to that off Cape Columbine, having a maximum northward velocity of $120 \mathrm{~cm} \mathrm{~s}^{-1}$ and a volume transport of about $7 \mathrm{~Sv}$.

The upwelling regime off southwestern Africa, and the associated frontal currents, have been reviewed in detail by Nelson and Hutchings (1983), Shannon (1985), and ChapMan and Shannon (1985), and we do not attempt to duplicate those efforts. But with the many studies in this region, there has developed an inconsistency in what the term 'Benguela Current' stands for. Traditionally, beginning with its introduction in the late 1800 s, this term has been used in reference to the large-scale northward flow at the eastern side of the South Atlantic subtropical gyre (KRÜMMEL, 
1882; SVERDRUP, JoHNSON and FLEMING, 1942). But drawing from the locally evolved terminology, HART and CURRIE (1960) suggested that usage of this term be reserved only for the region of cool upwelled water and northward jets near the coast, proposing that the adjacent circulation of subtropical water be called the 'Southeast Trade Wind Drift.' Adoption of this meaning for 'Benguela Current' can be found in a host of papers, such as DarbyshIRE (1963), STANDER (1964), Shannon (1966), Shannon and Van Ruswijck (1969), and Nelson and Hutchings (1983). More recently, though, LUTJEHARMS and STOCKTON (1987) and LUTJEHARMS and VALENTINE (1987) have left out the term 'Benguela Current' altogether in descriptions of the coastal upwelling off southwestern Africa, consistent with the large-scale view of the Benguela Current forming the eastern limb of the subtropical gyre.

As compared with the upwelling processes along the southwestern coast of Africa, the offshore portion of the Benguela Current, as the eastern limb of the South Atlantic subtropical gyre, has been little studied. SVERDRUP, JOHNSON and FLEMING (1942) estimated the northward geostrophic transport of this current at $30^{\circ} \mathrm{S}$ as being $16 \mathrm{~Sv}$ relative to a depth of about $1200 \mathrm{~m}$. STRAMma and PETERSON (1989) noted that a northward transport of $18.7 \mathrm{~Sv}$ in the upper $600 \mathrm{~m}$ in the eastern basin of the South Atlantic (east of $13^{\circ} \mathrm{W}$ ) can be extracted from Table 7 in Wüst (1957), which were based on observations made by the Meteor along $28^{\circ} \mathrm{S}$. Again using these Meteor data plus an inshore station at $25^{\circ} \mathrm{S}$, WoOsTER and REID (1963) calculated a Benguela Current transport of about $15 \mathrm{~Sv}$ relative to $1000 \mathrm{dbar}$. Applying inverse techniques on the Meteor and IGY (International Geophysical Year, 1957-1958) data, Fu (1981) derived a field of geostrophic transport (his Fig.9a) showing the Benguela Current as carrying approximately $20 \mathrm{~Sv}$ of surface water (less dense than $\sigma_{0}=26.8 \mathrm{~kg} \mathrm{~m}^{-3}$, nominally in the upper $500 \mathrm{~m}$ ) across $32^{\circ} \mathrm{S}$, whereupon the current widens considerably toward the northwest. Carried along with this northwestward flow is a $13^{\circ} \mathrm{C}$ thermostad which is formed in the thermocline of the eastern South Atlantic subtropical gyre by vertical mixing and with a possible contribution coming from the Indian Ocean (TsuchryA, 1986).

Most recently, Stramma and Peterson (1989) used historical data to compute the offshore geostrophic transport of the Benguela Current. They found that at $32^{\circ} \mathrm{S}$ the current is located near the African coast with a northward transport of about $21 \mathrm{~Sv}$ in the upper layer (Fig.9). Near $30^{\circ} \mathrm{S}$, the Benguela Current begins to separate from the eastern boundary as most of the flow turns toward the northwest. This northwestward flow carries about $18 \mathrm{~Sv}$ of surface water across $28^{\circ} \mathrm{S}$, whereupon it turns mainly toward the west to flow over a relatively deep segment of the Walvis Ridge south of the Valdivia Bank. A surface current with northward speeds of $10 \mathrm{~cm} \mathrm{~s}^{-1}$ was observed to flow along the western side of the Valdivia Bank, while another northward surface current of about $20 \mathrm{~cm} \mathrm{~s}^{-1}$ was seen some $300 \mathrm{~km}$ west of the bank. About $3 \mathrm{~Sv}$ of surface flow do not leave the Cape Basin south of the Valdivia Bank, but drift north out of the Cape Basin as a wide, sluggish flow into the Angola Basin.

\subsection{Equatorial Currents}

3.3.1. Components of the system. Several multi-institutional research programs have been conducted in the equatorial oceans in recent years, which for the Atlantic have included the GARP (Global Atmospheric Research Program) Atlantic Tropical Experiment (GATE), the First GARP Global Experiment (FGGE), the Seasonal Equatorial Atlantic (SEQUAL) program, and Programme Français Océan Climat Atlantique Equatorial (FOCAL). These have led to considerable improvements in the description and theory of equatorial processes and have added a wealth of information to the literature; assimilating all of it is well beyond the scope of this paper. Instead, we focus in this section on the basic upper-level structure and seasonal and interannual variability 
in the lower latitudes of the South Atlantic. For more comprehensive reviews concerning observation, theory, and modelling, the reader is referred to articles by PHILANDER (1973), MoORE and Phillander (1977), LeetmaA, McCreary and Moore (1981), Siedler and PhIl.ANDer (1982), SiEdler (1983), CANe and SARAchiK (1983), KnoX and ANDERson (1985), and Eriksen and Katz (1987).

Ship drift data have long been used to describe surface currents in the tropical Atlantic, as, for example, in the early work of Rennell (1832). Classically, the Benguela Current has been portrayed as feeding into a broad South Equatorial Current (SEC) that flows westward to the eastern promontory of South America, Cabo de São Roque, whereupon it bifurcates into the North Brazil Current (sometimes called the North Brazilian Coastal Current) and the Brazil Current. This bifurcation can also be seen in the trajectories of satellite-tracked drifting buoys (MoLINARI, 1983; REVERDIN and MCPHADEN, 1986). The North Brazil Current is the stronger of the two and continues into the northern hemisphere, partly accounting for the net northward transport of upper-level water from the South Atlantic to the North. This net transfer has been known for more than a century and a half; RENNELL (1832) was quite convinced of it, but was at a loss for a satisfactory explanation of how it could be. SVERDRUP, JoHnSON and FLEMING (1942) estimated the northward, cross-equatorial transport of surface water as being $6 \mathrm{~Sv}$ accompanied by $2 \mathrm{~Sv}$ of intermediate water and $1 \mathrm{~Sv}$ of bottom water, all being compensated by a southward transport of 9Sv of deep water. Using zonal sections along $24^{\circ} \mathrm{N}, 8^{\circ} \mathrm{N}, 8^{\circ} \mathrm{S}$, and $24^{\circ} \mathrm{S}$ to find a balance between geostrophic and Ekman flows, RoEмMICH (1983) computed a net upper-ocean northward transport of $10 \mathrm{~Sv}$ across each section. In the upper ocean between $8^{\circ} \mathrm{N}$ and $8^{\circ} \mathrm{S}$ he found a geostrophic convergence of $25 \mathrm{~Sv}$ compensated by an Ekman divergence of the same magnitude.

The equatorial current system is marked by variability occurring over wide ranges of time and space scales. Being that the Coriolis parameter vanishes in the presence of density stratification, the equatorial ocean can respond strongly to changes in the overlying wind fields. ERIKSEN and KATZ (1987) have pointed out that given a mean thermohaline state, equatorial variability is essentially driven by atmospheric forcing. And because of the low-latitude reduction of time scales and associated increases in space scales for baroclinic disturbances, this variability is dominated by wave-like motions, whereas eddy dynamics are more important at latitudes higher than about $5^{\circ}$ (SEEDLER, 1983). Fluctuations of current velocity in response to seasonal changes in equatorial wind stress fields should therefore be mainly zonal along the equatorial wave guide, and this has been statistically observed in ship drift data (RICHARDSON and WALSH, 1986). Also from ship-drift data, RICHARDSON and WALSH (1986) have derived maps of mean surface velocities in $2^{\circ}$ latitude by $5^{\circ}$ longitude boxes, which for the austral summer (February) and winter (August), together with the annually-averaged speeds, are shown in Fig. 10. In their maps, the austral winter strengthening of the North Equatorial Countercurrent (NECC), which is fed by the North Brazil Current (PhILANDER and PaCANOwski, 1986a,b) is clear, while in each season the SEC has strong westward flow (about $30 \mathrm{~cm} \mathrm{~s}^{-1}$ ) near the equator and weaker westward flow $\left(10-15 \mathrm{~cm} \mathrm{~s}^{-1}\right)$ in a broad band south of $10^{\circ} \mathrm{S}$. RICHARDSON and WALSH (1986) noted that the stronger portion of the SEC, that near the equator, has a banded structure in the annual mean; in the central part of the basin there is a maximum at $2^{\circ} \mathrm{N} 22.5^{\circ} \mathrm{W}$ and another at $4^{\circ} \mathrm{S} 17.5^{\circ} \mathrm{W}$.

The same data have been used by Arnault (1987), and Fig.11 shows her maps of the annual means of surface currents in $2^{\circ}$ latitude by $4^{\circ}$ longitude boxes in the tropical Atlantic from ship drifts, together with those from geostrophic computations relative to $500 \mathrm{dbar}$ and from computations of Ekman drift. Large differences appear between the ship drifts and surface geostrophic currents, but, except at the equator where Coriolis accelerations vanish, the differences are well accounted for by the Ekman drift which has larger amplitude in most regions than the geostrophic 

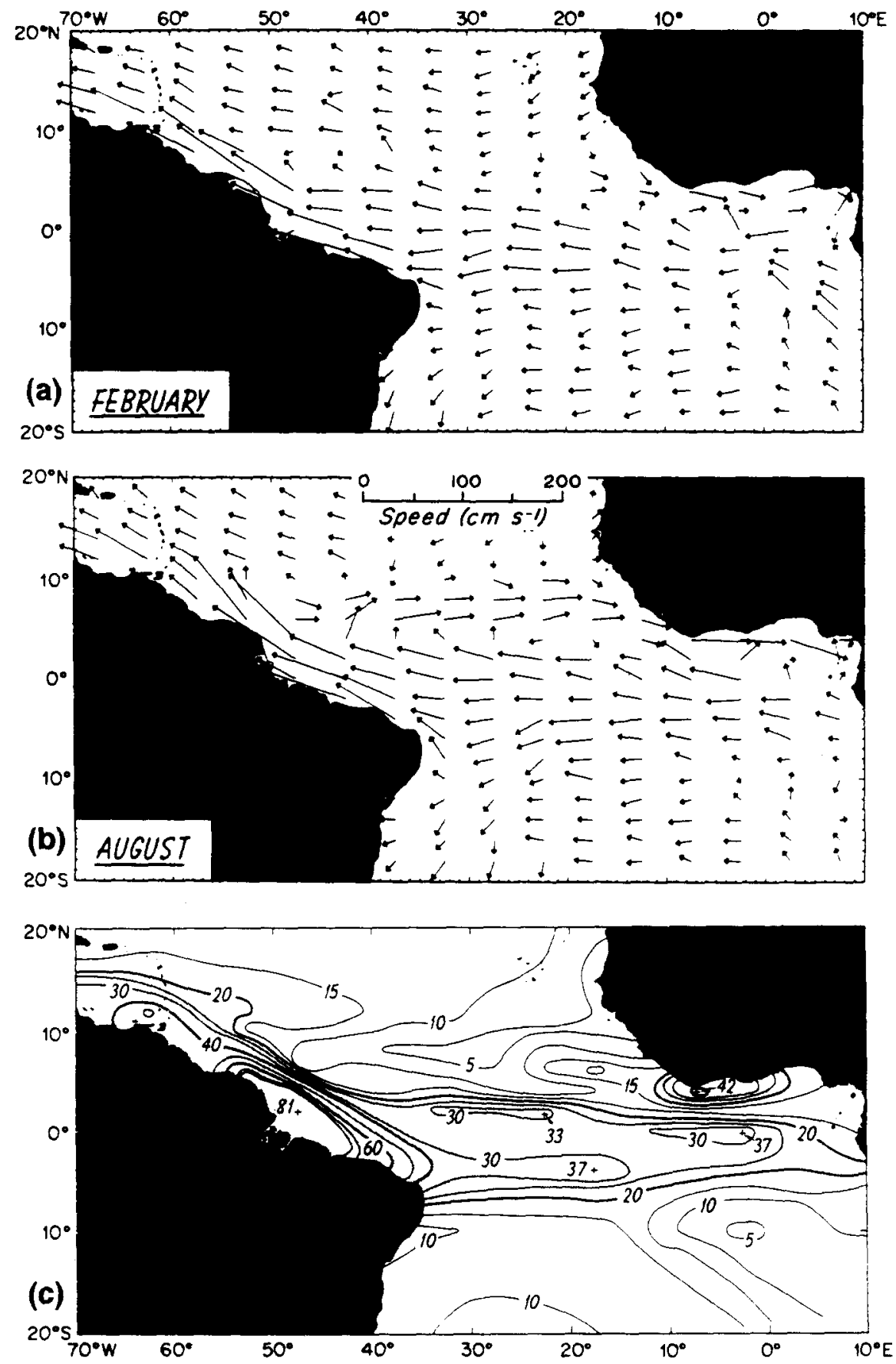

Fig. 10. Mean surface velocities from ship drift observations in $2^{\circ}$ latitude by $5^{\circ}$ longitude boxes for (a) February, (b) August, and (c) annually-averaged speed in $\mathrm{cm} \mathrm{s}^{-1}$ (RICHARDSON and WALSH, 1986). 
component. For the band of $2^{\circ}-8^{\circ} \mathrm{S}$, she found westward ship drift at all longitudes and all months, in agreement with the Ekman Drift, whereas east of $8^{\circ} \mathrm{W}$ the surface geostrophic flow is eastward in all months except June to September. It is interesting to note that in those months where the surface geostrophic flow is no longer eastward in the Gulf of Guinea and northern Angola Basin, there is also no Angola Dome present in the thermocline, a small-scale feature described in the following section. MerLe and ARNAult (1985) found the maximum variability of dynamic topography (relative to $500 \mathrm{~m}$ ) in the tropical Atlantic to occur in the Gulf of Guinea and north of the equator beneath the intertropical convergence zone (in the region of the NECC), whereas the seasonal variability is small in the entire western and central South Atlantic north of $20^{\circ} \mathrm{S}$.

The system of upper-level currents near the equator comprises a complex array of westward currents and eastward countercurrents. A revised version of DEFANT's (1936) generalization of equatorial currents in the Atlantic is contained in the paper by KNOLL, ZENK and BAUER (1982). While many of the three-dimensional details of how the bands are arranged across the width of the Atlantic and how water is transferred from one band to another are not yet worked out, there are still some generalizations worth making, but with the caveat that space-time variations will often produce a picture quite unlike the idealized, southern winter representation shown in Fig.12. As illustrated, the NECC lies roughly between $3^{\circ}$ and $10^{\circ} \mathrm{N}$ and is the northern boundary to the multiple-banded SEC; both of these currents are at their strongest and are at their most northerly positions during the austral winter.

As seen in Fig. 10, the SEC in the central Atlantic has velocity maxima just north and south of the equator. The relative minimum at the equator corresponds in position with that of the Equatorial Undercurrent (EUC), a narrow jet having a half-width of about $1.5^{\circ}$ latitude and eastward velocities often well over $100 \mathrm{~cm} \mathrm{~s}^{-1}$ in the upwelled thermocline a hundred meters or less from the sea surface. Metcalf, Voorhis and Stalcup (1962) and PhIl.ANDer (1973) have summarized the discovery of this relatively saline and oxygenated current. On the basis of temperature-oxygen relationships, MetCalf and StalCup (1967) found that most of the water in the EUC comes from the South Atlantic thermocline by way of the North Brazil Current with very little coming from the North Atlantic. This is also shown by the analysis of historical data by Tsuchrya (1986) and by the general circulation model of PHILANDER and PACANowski (1986b). In the thermohaline fields, this jet is prominent as a local vertical spreading of the thermocline and as a high salinity core with values of 36.5 or more in the western Atlantic as opposed to 35 to 35.5 in the surrounding water (METCALF, VoORHIS and STALCUP, 1962). As an average at $22^{\circ} \mathrm{W}$, FAHRBACH, MEINCKE and Sy (1986) found the salinity maximum of the EUC to be located $30 \mathrm{~km}$ south of the velocity maximum.

In general, the EUC is most intense in the western Atlantic and weakens as it flows east, with observations made during GATE (Düing, Hisard, Katz, Meincke, Miller, Moroshkin, PhulanDER, RIBNIKOV, VoIGT and WEISBERG, 1975) showing that the core of the current meanders between $0^{\circ} 50^{\prime} \mathrm{N}$ and $0^{\circ} 50^{\prime} \mathrm{S}$ over time scales of $2-3$ weeks (refer to Figs.13a-d for a half-cycle at $28^{\circ} \mathrm{W}$ ), consistent with a long $(2600 \mathrm{~km})$, unstable wave propagating westward with a phase speed of $1.9 \mathrm{~m}$ $\mathrm{s}^{-1}$. Along with the meandering, the EUC also displays a pulsating behaviour; the maximum core velocities at $28^{\circ} \mathrm{W}$ varied from around $60 \mathrm{~cm} \mathrm{~s}^{-1}$ to more than $120 \mathrm{~cm} \mathrm{~s}^{-1}$, and the volume transports obtained by integrating the velocities within the $20 \mathrm{~cm} \mathrm{~s}^{-1}$ isotachs ranged from 4 to $15 \mathrm{~Sv}$. The eastward weakening of the EUC is illustrated in Figs.13e-g, where the maximum core velocities decreased from over $80 \mathrm{~cm} \mathrm{~s}^{-1}$ at $12^{\circ} \mathrm{W}$ to only half as large at $4^{\circ} \mathrm{W}$, and to just over $30 \mathrm{~cm} \mathrm{~s}^{-1}$ at $4.5^{\circ} \mathrm{E}$. A feature to note in the easternmost section is that in addition to the EUC core near the equator there was another, and larger one centered near $1.5^{\circ} \mathrm{S}$. This may have been an early sign of part of the current turning into the southern hemisphere as it approaches the eastern boundary. Near the eastern boundary, at $6.5^{\circ}$ E, RINKEL, SUND and NEUMANN (1966) observed the high salinity 
$80^{\circ} \quad 70^{\circ} \quad 60^{\circ} \quad 50^{\circ} \quad 40^{\circ} \quad 30^{\circ} \quad 20^{\circ} \quad 10^{\circ} \mathrm{W} \quad 0^{\circ} \quad 1^{\circ} \mathrm{E} \quad 20^{\circ}$
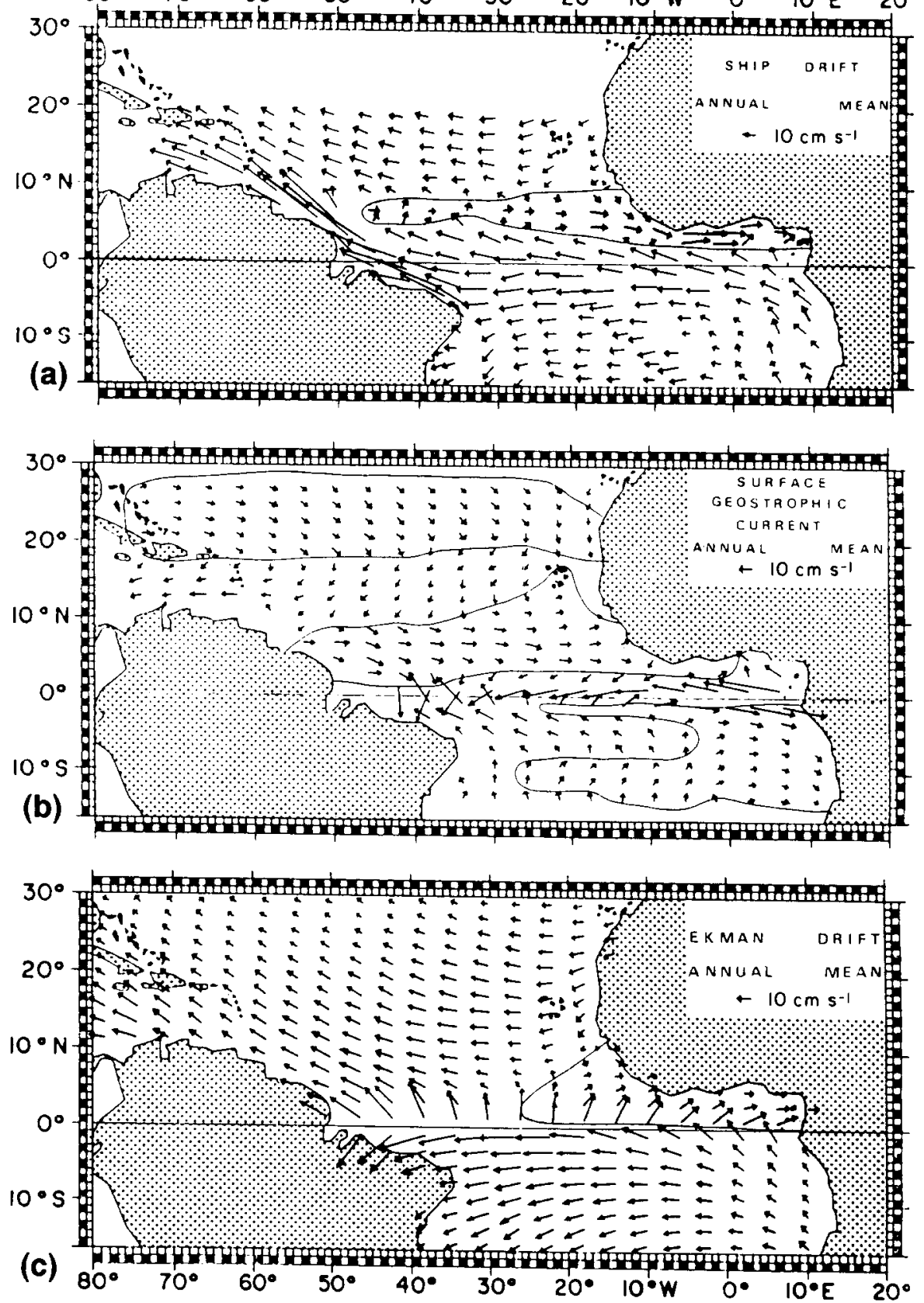

FIG. 11. Surface fields of annual mean (a) ship drift, (b) geostrophic velocity relative to $500 \mathrm{dbar}$, and (c) Ekman drift, all in $2^{\circ}$ latitude by $4^{\circ}$ longitude boxes (Arnault, 1987). 


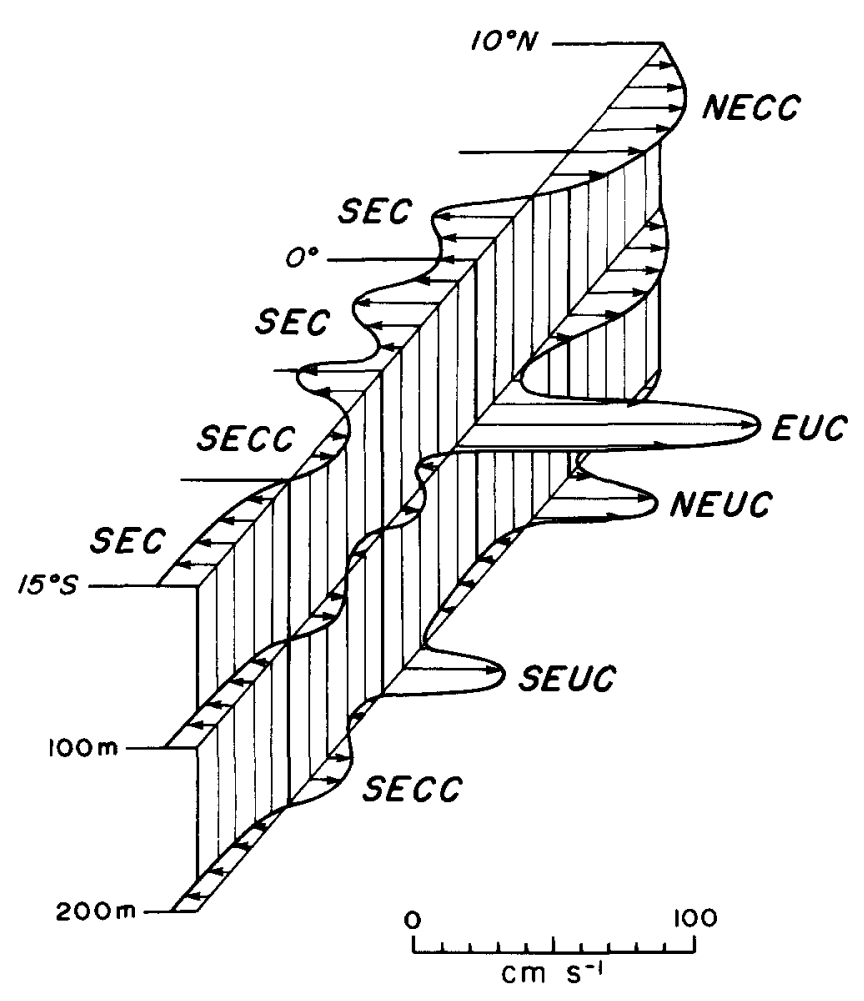

Fig. 12. Idealized representation of austral winter currents at 0,100 , and $200 \mathrm{~m}$ depth in the nearequatorial region of the central Atlantic. Abbreviated terms are: North Equatorial Countercurrent (NECC), South Equatorial Current (SEC), South Equatorial Countercurrent (SECC), Equatorial Undercurrent (EUC), North Equatorial Undercurrent (NEUC), and South Equatorial Undercurrent (SEUC).

core of the EUC to bend southeast before terminating $150 \mathrm{~km}$ from the African coast near $1^{\circ} 20^{\prime} S$. But on the basis of T-S curves, WAUTHY (1977) has traced EUC water to as far south as $13^{\circ} \mathrm{S}$. And most recently, WACONGNE and PITON (1990) have surmised that the EUC is probably continuous with the Gabon-Congo Undercurrent along the African coast at $1^{\circ}-6^{\circ} \mathrm{S}$, which in turn supplies water to the Angola Current farther south. This will be discussed in the following section.

The existence of the EUC has traditionally been thought of as being a direct result of westward pressure gradients associated with a zonal tilt of the sea surface: surface water accumulates in the west by the frictional action of the wind, and subsurface water returns to the east under the action of the pressure gradient force (i.e., ARTHUR 1960). Because of the change in sign of the Coriolis parameter at the equator, the westward winds lead to surface divergence and upward motion along the equator which are compensated by convergence at depth. The three-dimensional circulation involving the EUC has been addressed by many investigators, as PHILANDER (1973) has documented in detail. Recently, BRYDEN and BRADY (1985) studied the equatorial circulation in the Pacific with a diagnostic model and pointed out that the vertical motion occurs largely on the zonal plane in which eastward-moving fluid elements rise along upward sloping isopycnals. Because cross-isopycnal mixing was not needed for the vertical motion, PEDLOsKY (1987) was prompted 


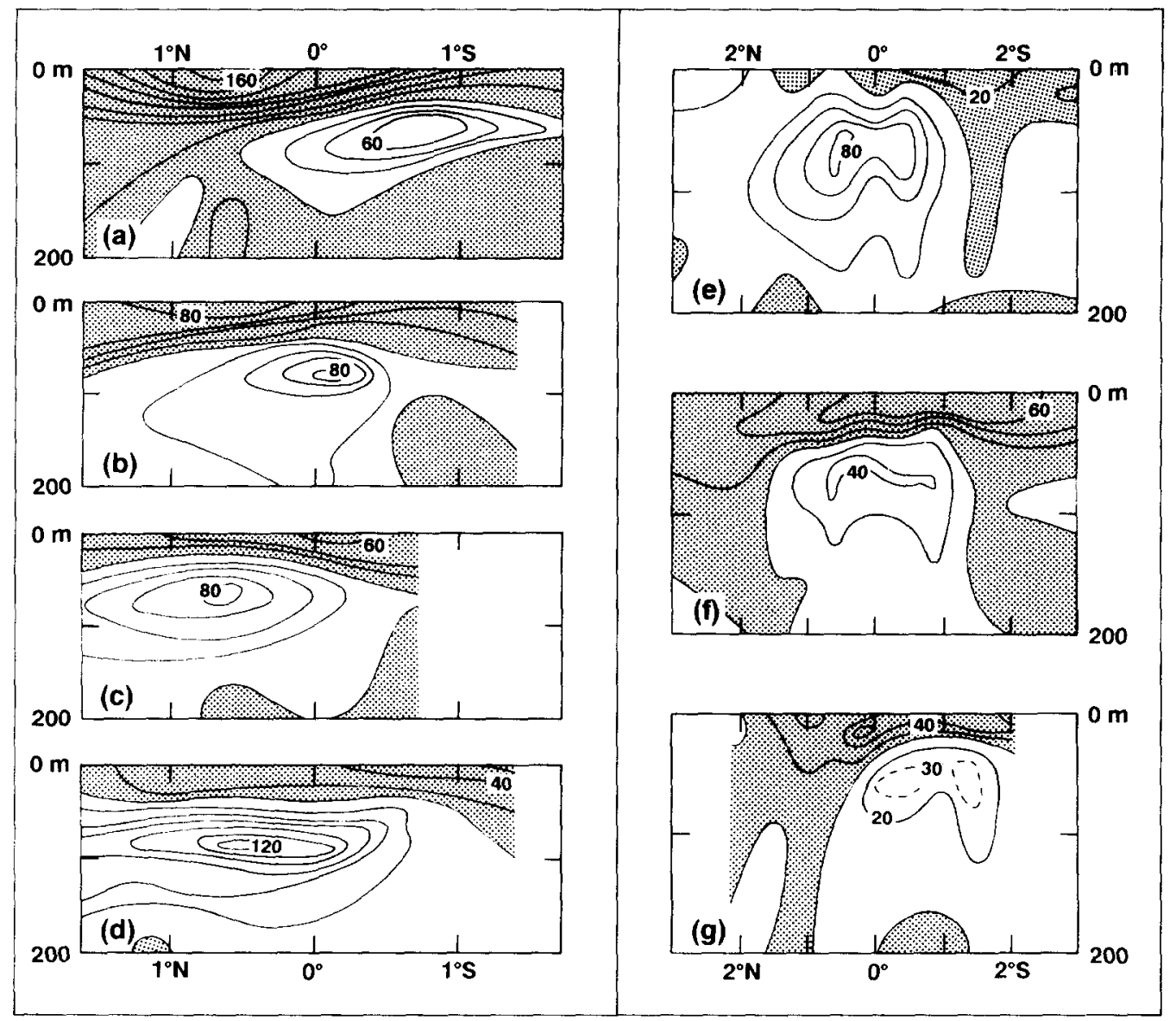

Fig. 13. Meridional sections of directly-measured eastward velocity $\left(\mathrm{cm} \mathrm{s}^{-1}\right)$ in the upper $200 \mathrm{~m}$ illustrating the Equatorial Undercurrent (shading denotes westward flow). Interval between solid contours is $20 \mathrm{~cm} \mathrm{~s}^{-1}$. The fields on the left were all measured at $28^{\circ} \mathrm{W}$ in the year $1974 \mathrm{from} \mathrm{R/V} \mathrm{Iselin}$ during (a) July 26-28, (b) July 30 - August 1, (c) August 2-3, and (d) August 4-6 (adapted from Dorng, Hisard, Katz, Metncke, Miller, Moroshkin, Phillander, Ribnikov, Voigt and Weisberg, 1975, by permission from Nature, Vol. 257, pp. 531-534. Copyright for original: 1975 Macmillan Magazines Ltd). The fields on the right were measured during April-June 1964 from MS Prof. A. Penck at (e) $12^{\circ} \mathrm{W}$, (f) $4^{\circ} \mathrm{W}$, and (g) $4.5^{\circ} \mathrm{E}$ (adapted from STuRM and Voigt, 1966).

to extend a simple argument based on the conservation of potential vorticity (FoFONOFF and MONTGOMERY, 1955) to explain the EUC. He developed an inviscid, non-linear, two-layer inertial model in which the Bernoulli function was conserved along the equator and where the far-field, extra-equatorial solution was matched with that of the ventilated thermocline model of LUYTEN, PedLosky and STOMmel (1983). But this purely non-frictional, vorticity-conserving model was unsatisfactory in that it produced an eastward accelerating current which is not observed. Using the numerical simulation of PHILANDER and PACANOWSKI (1984) to compute zonal momentum balances in the equatorial Atlantic, WACONGNE (1989) found that only near the western boundary 
does the subsurface eastward pressure gradient force exceed westward frictional forces, thus giving rise to an eastward current beneath westward surface flow; away from the western boundary friction dominates and the net force is westward, causing the undercurrent to weaken as it flows east. Dissipation in the form of cross-isopycnal entrainment of EUC water into the upper mixed layer was added by PEDLOSKY (1988) to his earlier model to get an eastwarddecelerating EUC, and in the third paper of the series, PEDLOSKY and SAMELSON (1989) added surface wind stress. This final model makes the three-dimensional linkage between the structure of the EUC and the equatorial winds, the extra-equatorial thermocline, and the conservation of potential vorticity and Bernoulli function. But this equatorially-symmetric solution is not completely applicable to the Atlantic EUC which gets most of its water from the South Atlantic thermocline.

Distinct from the thermocline EUC are deeper countercurrents just beneath the thermocline. In the central Atlantic, at $15^{\circ}$ and $20^{\circ} \mathrm{W}$, MAzEIKA (1968) observed a narrow, eastward geostrophic current centered near $4^{\circ} \mathrm{S}$ having maximum velocities of $30-60 \mathrm{~cm} \mathrm{~s}^{-1}$ (relative to $600 \mathrm{dbar}$ ) near $150 \mathrm{~m}$ depth. West of $25^{\circ} \mathrm{W}$, Cochrane, Kelly and Oling (1979) observed the presence of subthermocline countercurrents having maximum eastward geostrophic velocities of $40-50 \mathrm{~cm} \mathrm{~s}^{-}$ ${ }^{1}$ (relative to $800 \mathrm{dbar}$ ) centered near $4.5^{\circ} \mathrm{N}$ and $4.5^{\circ} \mathrm{S}$; in the south the maximum velocities were found near $200 \mathrm{~m}$ depth and were largely covered by westward flow at the surface. On average, the southern current was $209 \mathrm{~km}$ wide and transported $15 \mathrm{~Sv}$. Molinari, Vorturiez and DuNCAN (1981) proposed the names North Equatorial Undercurrent (NEUC) and South Equatorial Undercurrent (SEUC) for these subthermocline eastward flows following a convention already in use in the Pacific. In the western and central Atlantic they found the SEUC to be typically located between $3^{\circ}$ and $5^{\circ} \mathrm{S}$ with an average width of about $100 \mathrm{~km}$ and a core depth of 150 to $200 \mathrm{~m}$. The average geostrophic transport of this current in the western Atlantic was also $15 \mathrm{~Sv}$ (relative to $1000 \mathrm{~m}$ ). Using additional data at longitudes of $25^{\circ}-28^{\circ} \mathrm{W}$, MolinaRI (1982) observed the EUC transport to range from 5 to $23 \mathrm{~Sv}$, with maximum core velocities of about $40 \mathrm{~cm} \mathrm{~s}^{-1}$ (relative to $1000 \mathrm{~m}$ ) near $200 \mathrm{~m}$ depth; the overlying surface flow was at times eastward and at others westward. The source of the SEUC is the region off the coast of Brazil (Cochrane, KELLY and Ollang, 1979), and it appears that this current extends all the way across the Atlantic to feed water into the northern Angola Basin (VorTurIEZ, 1981; VorTURJEZ and HEREBLAND, 1982).

MoLINARI (1982) observed the SEUC to lie between two branches of the SEC, the northern one being between $1^{\circ} \mathrm{S}$ and the SEUC with a geostrophic transport ranging from 6 to 23Sv (relative to $1000 \mathrm{~m}$ ) toward the west, while the other was just south of the SEUC with a comparable westward transport of $7-26 \mathrm{~Sv}$. South of the second branch, at $7^{\circ}-9^{\circ} \mathrm{S}$, another distinct eastward flow was observed, the South Equatorial Countercurrent (SECC). As with the SEUC, its maximum geostrophic velocities were beneath the surface $\left(10 \mathrm{~cm} \mathrm{~s}^{-1}\right.$ near $275 \mathrm{~m}$ depth), but was typically accompanied by eastward flow at the sea surface. Its geostrophic transport was estimated to range between 3 and $7 \mathrm{~Sv}$ relative to $1000 \mathrm{~m}$. The SECC was first observed by REID $(1964 \mathrm{a}, \mathrm{b})$ near $14^{\circ} \mathrm{W}$ between $5^{\circ}$ and $12.5^{\circ} \mathrm{S}$ in a section made in July 1963 in which maximum eastward velocities of $9 \mathrm{~cm} \mathrm{~s}^{-1}$ were found at depths of $200-250 \mathrm{~m}$, also accompanied by eastward flow at the surface. As will be discussed in Section 3.3.3, anomalous conditions were being experienced in the tropical Atlantic at that time which may have given rise to a stronger than normal SECC. As with the SEUC, it appears that the SECC extends all the way across the ocean and turns southward in the eastern Angola Basin (Moroshkiv, BubNov and Bulatov, 1970; SHANNON, Boyd, Brundrit and TAunton-Clark, 1986).

From the thermostad investigation of TsuchryA (1986) and the inverse computations of Fu (1981), it is evident that the main westward current of the South Atlantic subtropical gyre lies generally to the south of $10^{\circ} \mathrm{S}$ and reaches that latitude only near the coast of Brazil. MoLINARI 
(1982) estimated that the southern branch of the SEC (south of the SECC) transports only 3Sv relative to $1000 \mathrm{~m}$, but the sections he used extended to just $11^{\circ} \mathrm{S}$, thus leaving the northern limb of the subtropical gyre largely unsampled. Using historical data, STRAMMA, IKEDA and PETERSON (1990) found the southern branch of the SEC to carry about $16 \mathrm{~Sv}$ in the upper $500 \mathrm{~m}$ (relative to about $1200 \mathrm{~m}$ ) across $30^{\circ} \mathrm{W}$ (Fig. 14). They observed the SEC to bifurcate near $10^{\circ} \mathrm{S}$ in the months of February and March, whereupon approximately 12Sv turned north into the North Brazil Current and only $4 \mathrm{~Sv}$ south into the Brazil Current. It is not known if there is any seasonal variability in the location and character of the SEC bifurcation, as the available data are inadequate for addressing this.

3.3.2. Angola Basin circulation. The northward surface drift out of the Cape Basin, noted at the end of Section 3.2, together with the flow of cool, upwelled water along the African coast, reaches to about $15^{\circ}-17^{\circ} \mathrm{S}$, depending on season, before coming into contact with warm surface waters in the Angola Basin (Shannon, AgEnBag and BuYs, 1987). A sharp thermal front, first observed by HART and CURRIE (1960), develops there and marks the southern boundary to surface circulation in the Angola Basin. This front, the Angola-Benguela Front, is well developed in the upper $50 \mathrm{~m}$, and can be detected in the salinity field to depths of at least $200 \mathrm{~m}$ (SHANNON, AgENBag and BUYs, 1987; GoRDON and BosLey, 1990).

According to MAZEIKA (1967), a feature which stands out in the upper-layer temperature distribution during southern summer, but not winter, is a doming of shallow isotherms centered off the Angola coast near $10^{\circ} \mathrm{S} 9^{\circ} \mathrm{E}$. This "Angola Dome" is analogous to a similar feature, the "Guinea Dome," which occurs during northern summer off the African coast near $10^{\circ} \mathrm{N}$. These features, and their seasonality, are depicted in Fig.15. MAZEIKA (1967) observed that the Angola Dome is evident in historical means at depths of $20 \mathrm{~m}$ to $150 \mathrm{~m}$, but can not be detected in fields of sea surface temperature. Being that the Angola Basin was sampled in the IGY during the southern summer, this thermal dome can be seen in the temperature section made by the Crawford at $8^{\circ} \mathrm{S}$, and to some extent in the section at $16^{\circ} \mathrm{S}$ (FUGLISTER, 1960). Also according to MAZEIKA (1967), salinities are 0.3-0.5 lower and oxygen values 2-3 $\mathrm{ml} \mathrm{l}^{-1}$ less within the Angola Dome as compared with surrounding waters on equal isopycnic surfaces, and that upwelling is probably involved in its formation (such upwelling would not be a part of the coastal upwelling regime found farther south, which at this time of year is most vigorous near the southern end of Africa). VorTURIEZ (1981) has presented evidence that although the Angola Dome is a seasonal feature in the thermocline, it is probably permanent beneath the thermocline. According to him, the SEUC (roughly $200 \mathrm{~m}$ deep) induces a permanent subthermocline thermal dome when it turns poleward near the eastern boundary, and that the thermocline portion of the dome corresponds to a seasonal uplifting of the deeper structure when low atmospheric pressure and favorable wind stress curl cause upwelling. VoITURIEZ and HERBLAND (1982) have presented additional evidence for this, and WACONGNE and PITON (1990) considered the southward turn of the SEUC to be a source of water for a highly variable poleward undercurrent they observed in current meter measurements taken at the continental shelf break at $1^{\circ}-6^{\circ} \mathrm{S}$. This undercurrent, which WACONGNE and PITON (1990) referred to as the Gabon-Congo Undercurrent, was observed to have an average velocity of $8 \mathrm{~cm}$ $\mathrm{s}^{-1}$ toward the south, and they conjectured that it feeds into the Angola Current farther south.

The first quasi-synoptic hydrographic survey of the Angola Basin was made by the Kurchatov from 5 April to 9 June 1968, during the southern autumn. Measurements from that cruise were used by Moroshrin, BuBNov and BuLATOv (1970) to observe a cyclonic geostrophic gyre less than $1000 \mathrm{~km}$ across (according to their figures) and centered near $13^{\circ} \mathrm{S} 4^{\circ} \mathrm{E}$, more than $600 \mathrm{~km}$ southwest of the thermal dome. The gyre extended from just beneath a very thin $(10-20 \mathrm{~m})$ wind- 


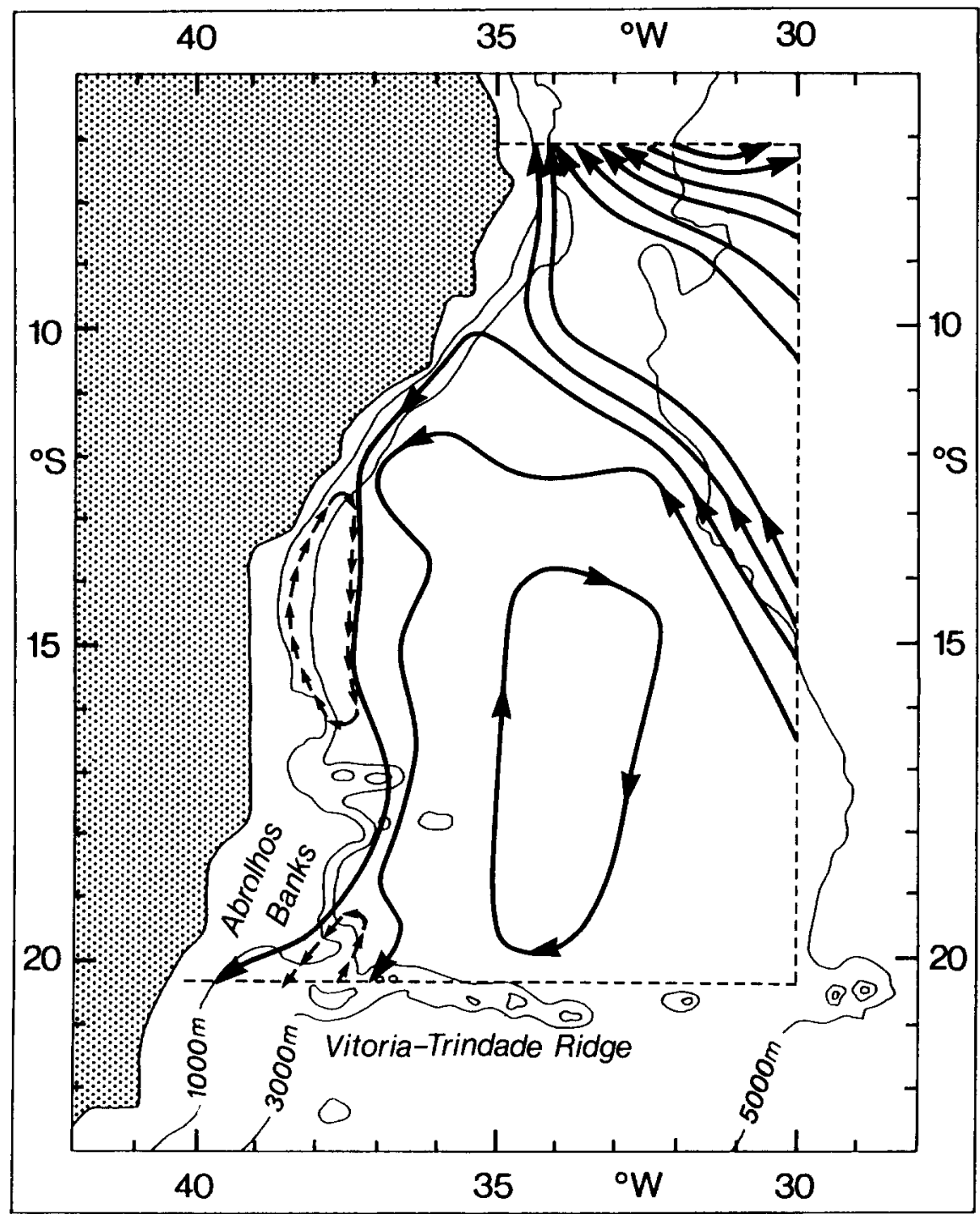

FIG. 14. Schematic representation of the geostrophic flow field in the upper $500 \mathrm{~m}$ based on historical hydrographic data within the region defined by the dashed box. Solid flow lines represent a transport of $2 \mathrm{~Sv}$, disconnected arrows a transport of $1 \mathrm{~Sv}$. The location of where the South Equatorial Current bifurcates is based on data obtained in the months of February and March. Reproduced from STRAMMA, IKEDA and PETBRSON (1990). 


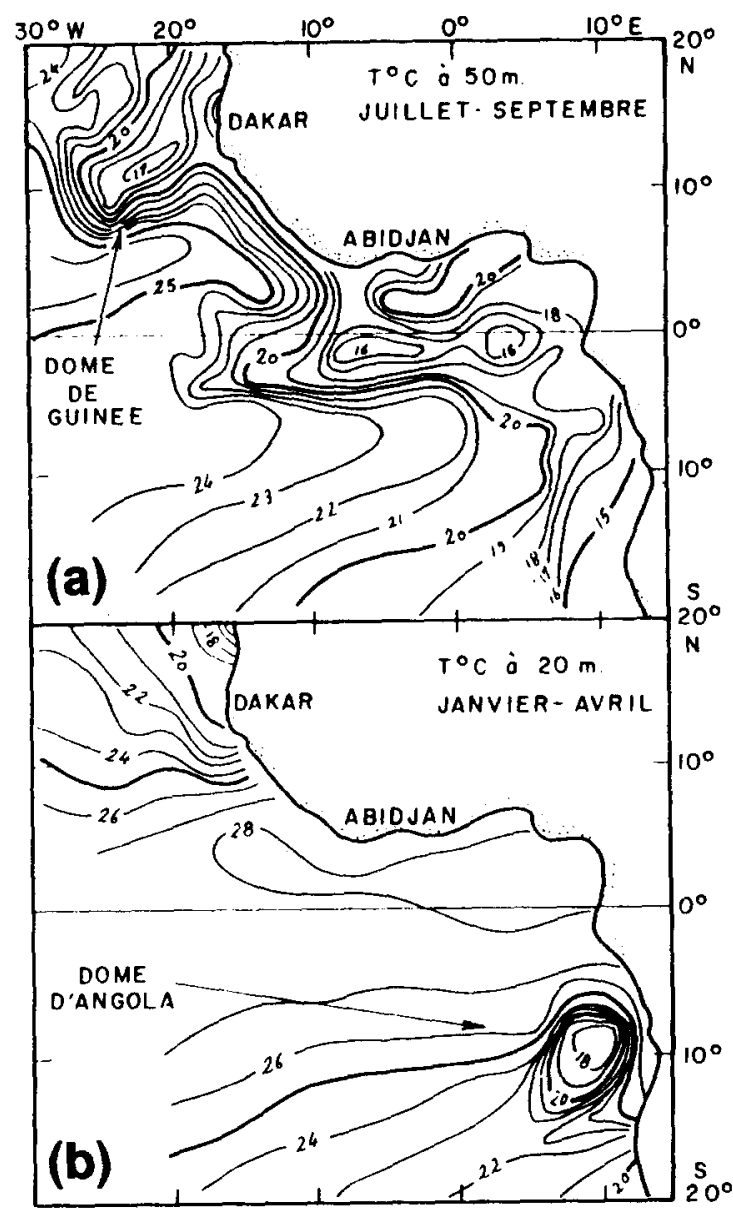

FIG. 15. Thermocline domes in the eastern Atlantic revealed by average distributions of temperature $\left({ }^{\circ} \mathrm{C}\right)$ based on bathythermograph and hydrographic station data from the years 1905-1963 for (a) austral winter (July-September) at $50 \mathrm{~m}$ depth and (b) austral summer (January-April) at $20 \mathrm{~m}$ depth (adapted from MAZzira, 1967 by VoITURIEZ, 1981).

driven surface layer to about $300 \mathrm{~m}$ depth, and produced subsurface southward velocities of up to $50 \mathrm{~cm} \mathrm{~s}^{-1}$ in a narrow coastal current which they referred to as the Angola Current. As Vorturiez (1981) noted, the Angola Dome observed by MAzEIKA (1967) and the cyclonic gyre described by Moroshin, BuBnov and Bulatov (1970) are two different phenomena. By inverting historical data to estimate the absolute geostrophic circulation in the South Atlantic, ReI (1989) has also found cyclonic motion north of the seaward extension of the Benguela Current, and his maps of adjusted steric height show this gyre to be more of a basin-wide feature centered at roughly $10^{\circ} \mathrm{W}$ and extending downward to at least $1500 \mathrm{dbar}$ as a recognizable, closed circulation. GoRDON and BOSLEY (1990) have subsequently observed a cyclonic gyre in a collection of station data taken in the region during a number of hydrographic surveys in 1983-1984 (Fig.16). They found the 
gyre to be centered at approximately the same location as did Moroshin, BubNov and Bulatov (1970), but Fig.3a in GoRDON and BosLEY (1990) indicate that it is a larger feature, perhaps $2000 \mathrm{~km}$ across. Additionally, GorDon and BOSLEY (1990) observed the sea surface at the gyre's center to be about 8 dynamic centimeters (relative to $1500 \mathrm{dbar}$ ) lower than that of the surrounding region, and that its baroclinic signature is confined mainly to the upper 300dbar. Surface geostrophic speeds around the gyre were $2-4 \mathrm{~cm} \mathrm{~s}^{-1}$, and the associated volume transport was typically $5 \mathrm{~Sv}$ in the upper $300 \mathrm{dbar}$ relative to $1500 \mathrm{dbar}$. They also pointed out that the winddriven surface layer has larger velocities which effectively mask the gyre from being observed with ship-drift data. Although the curl of wind stress is negative in the northeastern South Atlantic (Fig.6), BosLEy (1990) has argued, on the basis of a linear, two-layer model with wind forcing and upwelling, that Sverdrup dynamics alone do not fully account for the gyre.

As opposed to the Angola Dome, which appears to be bounded to the north by the SEUC, the larger cyclonic gyre is often considered to have as its northern boundary the SECC (MOROSHKIN, Bubnov and Bulatov, 1970; Shannon, Agendag and Buys, 1987; Gordon and Bosley, 1990), which together with the EUC and SEUC probably feeds into the Angola Current. But the southward flow in the region of the Angola Current appears to be significantly deeper than the equatorial currents coming in from the north, at least at times. Using a composite of historical data, KIRWAN (1963) performed an objective, isentropic analysis showing southward flow off Angola at depths of $300-1000 \mathrm{~m}$. His data in the Angola Basin consisted of both the Meteor and IGY measurements. FU (1981) applied inverse techniques on the IGY data and obtained similar results off Angola at $8^{\circ} \mathrm{S}$, i.e., southward flow from the surface down to the Upper North Atlantic Deep Water. This, however, was not observed in the Meteor data at the same location, by neither Fu (1981) nor WÜst (1957). Those Meteor stations were occupied in late August 1926, whereas the IGY stations, made from the Crawford, came in early March 1957, indicating that significant temporal (perhaps seasonal) variability in the deeper flow occurs in the eastern Angola Basin. REID's (1989) analysis of historical data show southward flow in the eastern Angola Basin to at least 3000dbar, while Gordon and BosLEy (1990) found only weak evidence of North Atlantic Deep Water moving south in the region.

3.3.3. Large-scale variability and interannual warmings. The focus of this section is the interannual variability that occurs in the tropical Atlantic, and to some extent the annual changes as well, both of which have been likened to the El Niño/Southern Oscillation (ENSO) phenomenon in the Pacific. Here we will only mention a few of the more salient features of the Pacific ENSO events; for more details regarding the meteorological and oceanographic aspects of these, the reader is referred to papers by Rasmusson and WALLACE (1983), CANE (1983) and KNox and ANDERSON (1985).

In the equatorial Pacific, the thermally-driven Walker circulation dominates the lower $10 \mathrm{~km}$ or so of the atmosphere. Under normal conditions, this circulation is characterized by rising motion and precipitation in the far western Pacific and Indonesia, eastward flow in the upper troposphere, subsidence of dry air in the eastern Pacific, and westward flow at the sea surface which supports a zonal tilt in sea level. During a typical ENSO event, the intertropical convergence zone (ITCZ), a narrow, zonal band of low-level convergence, shifts south and consequently the zonal pressure gradient at the surface along the equator diminishes. The trade winds near the date line and at locations farther west thereby undergo a relaxation, or even shift to eastward flow. Packets of equatorially-trapped downwelling Kelvin waves are then excited, which move eastward across the basin, and in a few months, arrive at the Ecuador-Peru coast causing rises in both sea level and sea surface temperature (SST). The zones of heavy rains that 


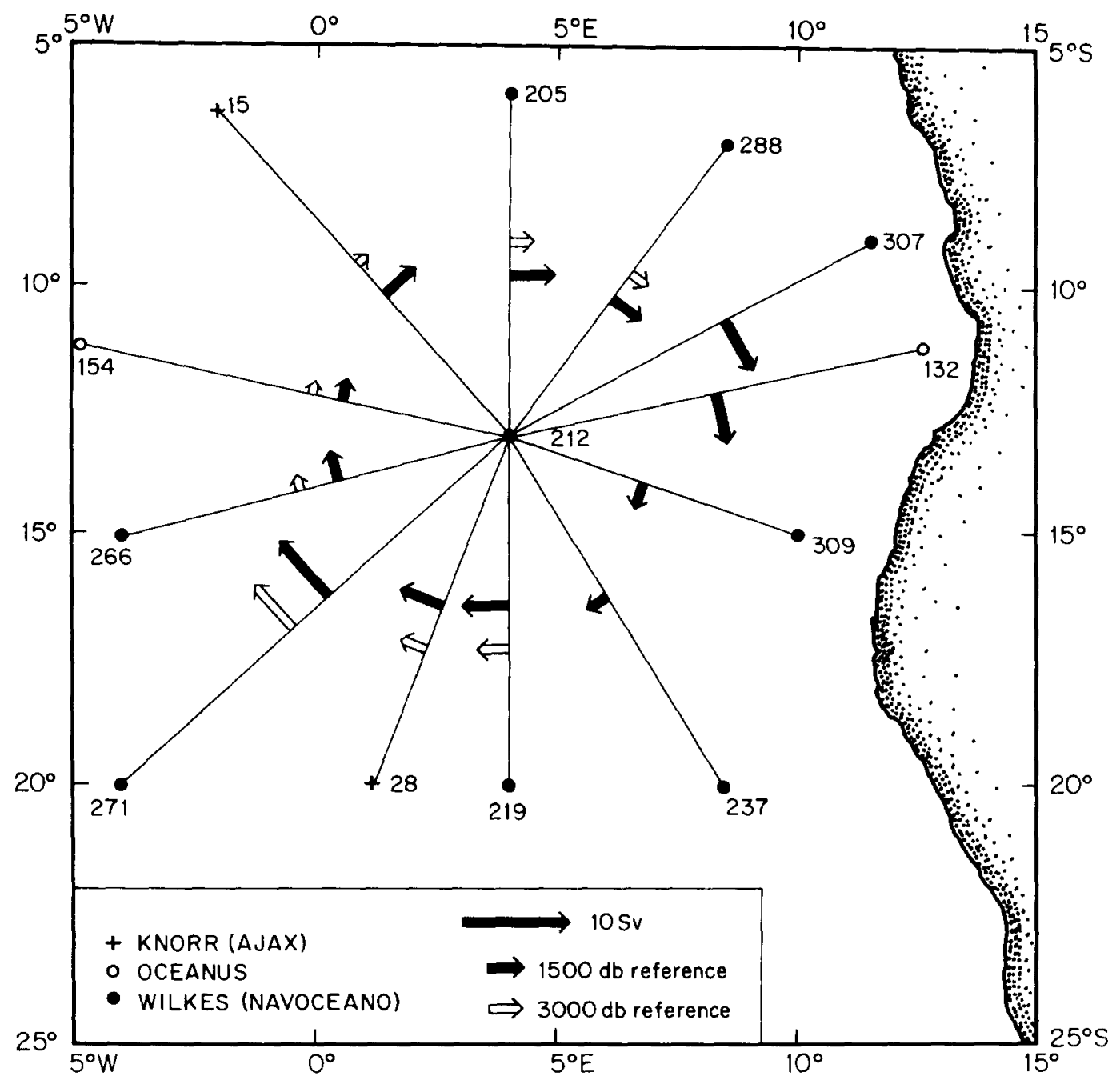

FIG. 16. Map of the transport between the surface and $300 \mathrm{dbar}$ referenced to $1500 \mathrm{dbar}$. Values using a $1500 \mathrm{dbar}$ reference level are solid, while those using a $3000 \mathrm{dbar}$ reference level are open. The eastern stations do not extend to 3000dbar. Station dates: 132, 154 (Oceanus) - March 1983; 15, 28 (Knorr) - October 1983; 205, 212, 219, 237 (Wilkes) - May 1984; 266, 271 (Wilkes) - June 1984; 288 (Wilkes) - July 1984; 307, 309 (Wilkes) - November 1984. From Gordon and BosLey (1990).

normally occur over the far western Pacific and Indonesia move east to normally arid regions, leaving the western Pacific in drought.

There is no close analogy in the equatorial Atlantic (Fig.3) to the zonal atmospheric pressure gradient in the Pacific, and consequently, there is no preferred region of heavy precipitation such as that which normally occurs in Indonesia. Instead, a band of precipitation is associated with the ITCZ which extends across the Atlantic and seasonally migrates north and south between the equator and about $15^{\circ} \mathrm{N}$. It reaches its southernmost latitude in March and April, bringing a rainy 
season to northeastern Brazil. In some years the rains fail, and such years of drought are known as Sêcas. CAVIEDES (1973) noted that El Niño events in the Pacific and Sêcas in northeastern Brazil occasionally occur at the same time, a connection that was investigated by HASTENRATH and HELLER (1977). On the basis of maps of general atmospheric circulation in the tropics, they found a strong negative linkage between rainfall in northeastern Brazil and SST along the Ecuador-Peru coast, and that Sêcas characteristically occur when the South Atlantic subtropical high expands equatorward and the ITCZ moves farther north. During those periods, the South Atlantic trade winds become stronger than normal and anomalously cold surface water appears in much of the equatorial Atlantic. They also suggested that an inverse relationship exists between long-term atmospheric pressure variations over the eastern South Pacific and South Atlantic oceans, which was in turn confirmed by CoveY and HASTENRATH (1978).

As opposed to the tropical Pacific, where interannual variations in SST exceed weak annual signals (see for example Fig. 1 in BJERKNES, 1969), the tropical Atlantic experiences annual changes in SST of $6^{\circ}-8^{\circ} \mathrm{C}$ (HASTENRATH and LAMB, 1977) that are substantially greater than the interannual (MERLE, 1980). The restriction of the surface signature of equatorial upwelling in the Atlantic to the northern summer season is the primary reason. Also during the northern summer, seasonal upwelling occurs in the northern Gulf of Guinea, but apparently not as a result of local winds or oceanic circulation (Houghton, 1976). Analogous to theories concerning the interannual El Niño events in the Pacific where downwelling Kelvin waves are involved, MOORE, HISARD, McCreary, Merle, O'Brien, Picault, Verstraete and Wunsch (1978) proposed that the annual upwelling in the Gulf of Guinea results from wind excitation of an equatorially trapped upwelling Kelvin wave in the western Atlantic which propagates eastward into the region. According to a linear, two-layer numerical model formulated by O'BRIEN, ADAMEC and MOORE (1978) and ADAMEC and O'BRIEN (1978), an increase in westward wind stress over the western equatorial Atlantic excites a disturbance that propagates eastward along the equator at internal gravity wave speeds to later produce strong upwelling in the Gulf of Guinea; local winds could not account for this upwelling. An adjustment phenomenon similar to the one believed to cause the interannual El Niño in the Pacific is thus part of the annual cycle in the Atlantic (MERLE, 1980), and one which can be enhanced in the Gulf of Guinea by a surfacing of the thermocline (MERLE, FIEUX and HISARD, 1980). Other numerical studies have produced similar results (for example, MCCREARY, PiCAult and MoORE, 1984), and recent in situ observations also provide support for the idea that the thermocline shoalings in the Gulf of Guinea are remotely forced by winds farther west in the equatorial Atlantic (Houghton and Colin, 1986; Houghton, 1989).

The intensity of upwelling in the Gulf of Guinea decreases in certain years and is occasionally accompanied by large positive anomalies $\left(>2^{\circ} \mathrm{C}\right)$ in SST linked to anomalous southerly positions of the ITCZ (MERLE, 1980). One such warming occurred in 1968, coinciding with intensifications of the North Equatorial Countercurrent and the Equatorial Undercurrent, southward movements of the ITCZ, and abnormally high levels of rain fall in the Gulf of Guinea; all these phenomena indicated that a real El Niño-like response had occurred in the eastern tropical Atlantic (HISARD, 1980). This response was preceeded by abnormal wind forcing off the northern coast of Brazil, consistent with observations of historical non-seasonal variability of SST in the Gulf of Guinea being highly and inversely correlated (with a one-month lag) with non-seasonal fluctuations of the trade winds in the western equatorial Atlantic (SERvain, Picault and MerLe, 1982). Although the factors responsible for anomalous variations in the trade winds in the western Atlantic are not understood, HIRST and HASTENRATH (1983) have deduced that such variations constitute an early link in a long and complex chain of events culminating in the appearance of abnormally warm 
surface water off the coast of Angola and anomalously large amounts of coastal rainfall. They found that the anomalous relaxation of trade winds in the western equatorial Atlantic accounts for $23 \%$ of the variance of SST off the Angola coast, whereas local wind forcing accounts for only $9 \%$.

During the southern summer, when the thermocline dome is present in the Angola Basin (Section 3.3.2) and the most vigorous coastal upwelling in the Benguela Current region is displaced southward (Section 3.2), warm and salty waters from the Angola Basin penetrate poleward to depths of $50 \mathrm{~m}$ or more to regions offshore of northern and central Namibia (O'ToOLE, 1980; SHANNON, 1985). However, major southward intrusions of warm and saline water into the upelling regions south of $15^{\circ} \mathrm{S}$, comparable to those observed during Pacific El Niño events off western South America, are relatively rare. Shannon, BoYd, Brundrit and Taunton-Clark (1986) argued that from the early 1950 s only two such intrusions have occurred, those being in 1963 and 1984. They also documented evidence for an El Niño-like event in 1934 and an unusually strong warm anomaly in 1950 . However, using historical sea surface temperatures in the southeastern Atlantic, TAUNTON-CLARK and SHANNON (1988) found evidence for a greater frequency of such events, more on the order of every ten years or so.

The strongest Pacific El Niño event of this century was that of 1982-83 (CANE, 1983; HoreL, KoUSKY and KAGANO, 1986). In 1983 there were extreme dry conditions in northeastern Brazil (LAmb, PePPler and Hastenrath, 1986; Fig.4 in Rasmusson and Wallace, 1983), anomalously strong trade winds and high surface pressures in the tropical Atlantic and low SSTs in the equatorial regions (HoREL, KOUSKY and KAGANO, 1986), a continuation of unusually vigorous upwelling along the coastal regions of the northern Benguela Current that began in 1982 (ShanNon, Boyd, Brundrit and TAUNTON-Clark, 1986), and severe drought in southern Africa (TAUNTON-ClARK and SHANNON, 1988). Also occurring during the austral summer of 1982-83 was a warming in the southern portions of the upwelling regime of the Benguela Current (SHANNON, BOYT, BRUNDRT and TAUNTON-CLARK, 1986). This might be compared with Fig. 3 in the paper by COVEY and HASTENRATH (1978), which shows that when averaged over ten Pacific El Niño years higher than normal SSTs are found during late summer along the southwest African coast.

With the following year, 1984, came the most intense warm event the tropical Atlantic had experienced for two decades. The fields of SST from June 1983 and June 1984 shown in Fig. 17 illustrate the magnitude of this most recent extreme event. Surface flow in the equatorial Atlantic slowed to near zero westward velocities in February-April 1984 (REvERDin and McPHADEN, 1986), and anomalously warm surface waters penetrated into the northern upwelling regime of the Benguela Current system on a scale observed only once before (SHANNON, BoYd, BRUNDRT and Taunton-Clark, 1986), in the middle of 1963 as described by STANDER and De Decker (1969). During the 1984 event, positive anomalies of almost $3^{\circ} \mathrm{C}$ were observed at the coast near $23^{\circ} \mathrm{S}$, but in the southern regions of the upwelling regime the effects were minimal; the higher SSTs were accompanied by an unusually large southward shift of the ITCZ (also a feature of Pacific ENSO events) and heavy rains in northeastern Brazil and the coastal zones of equatorial and southwestern Africa. However, there was no analogy to the eastward displacement of the region of heavy precipitation typically observed during Pacific El Niños (PHILANDER, 1986).

\subsection{Brazil Current}

A schematic view of the Brazil Current is given in Fig. 18 which depicts many of the features 

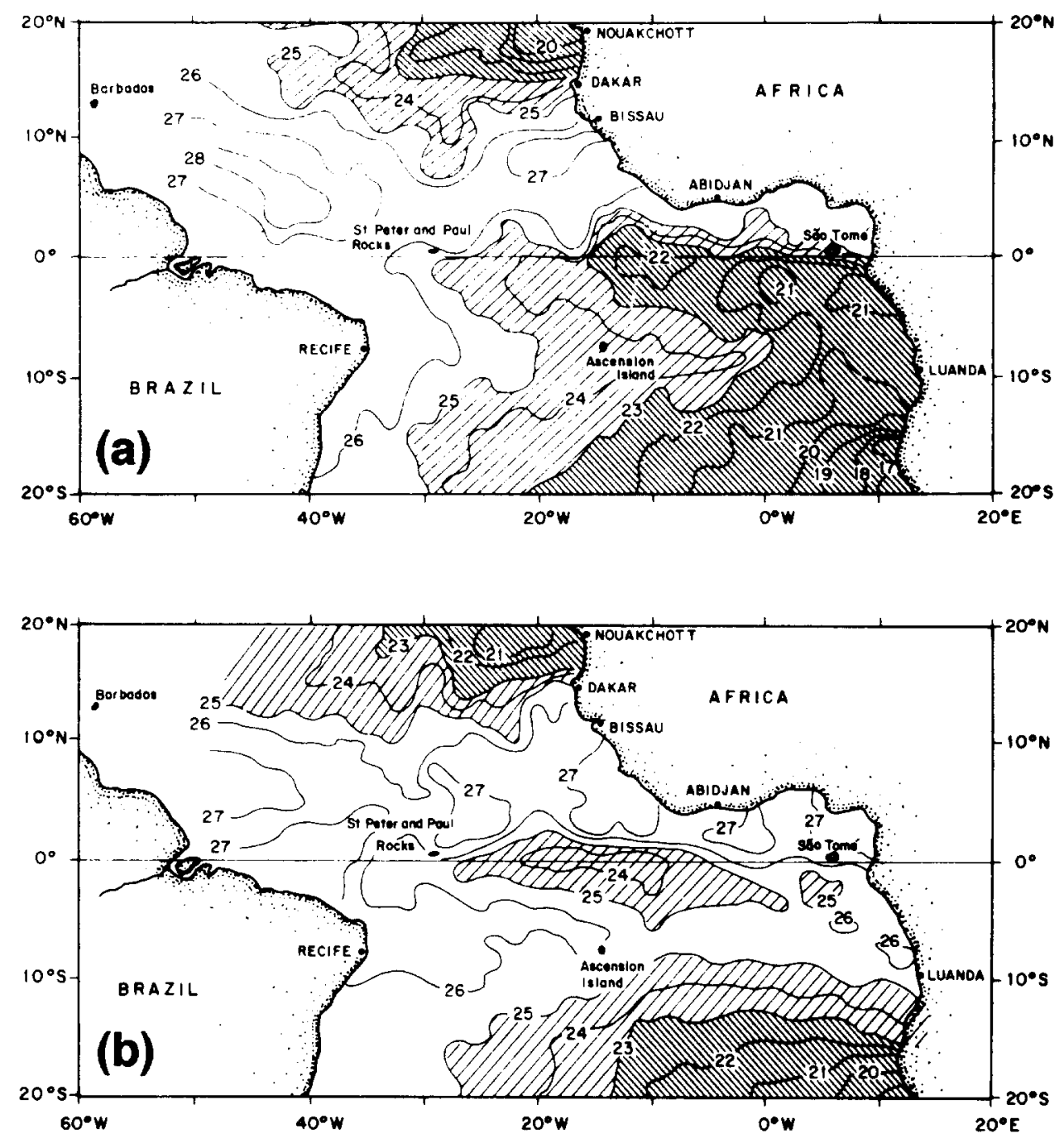

Fig. 17. Sea surface temperatures $\left({ }^{\circ} \mathrm{C}\right.$ ) in the tropical Atlantic in (a) June 1983 and (b) June 1984 (PHLLANDER, 1986; reprinted by permission from Nature, Vol. 322, pp. 236-238. Copyright 1986 Macmillan Magazines Ltd.).

discussed below. One feature already commented upon (end of Section 3.3.1) is that most of the water carried toward Brazil by the southern SEC enters the North Brazil Current, and that only about $4 \mathrm{~Sv}$ turn south near $10^{\circ} \mathrm{S}$ to feed the incipient Brazil Current. Because much of the transport in the northern limb of the South Atlantic subtropical gyre is lost to the northern hemisphere and to equatorial countercurrents, the northern Brazil Current is conspicuously weak when compared with other western boundary currents. And the Brazil Current transport remains relatively small over most of its southward course. Stramma, IkEda and Peterson (1990) found no systematic 
strengthening of the current between the latitudes of $10^{\circ}$ and $20^{\circ} \mathrm{S}$, and of the several estimates of Brazil Current transport from the region of $19^{\circ}$ to $25^{\circ} \mathrm{S}$ all are $11 \mathrm{~Sv}$ or less (Table 2).

A problem encountered when estimating the transport of the Brazil Current in its more northerly reaches is that it is shallow and closely confined to the continental shelf. At $19^{\circ} \mathrm{S}$, MIRANDA and CASTRO FILHO (1982) calculated a maximum southward surface velocity of $72 \mathrm{~cm} \mathrm{~s}^{-}$ ${ }^{1}$ relative to about $500 \mathrm{~m}$, finding that over $50 \%$ of the current transport of $6.5 \mathrm{~Sv}$ was contained in the upper $200 \mathrm{~m}$. In the region of a seamount chain at $20.5^{\circ} \mathrm{S}$, EvaNs, SIGNORIN and MiRANDA (1983) observed maximum surface speeds of $50-60 \mathrm{~cm} \mathrm{~s}^{-1}$ relative to $500 \mathrm{~m}$ as the current flowed through a passage nearly $2000 \mathrm{~m}$ deep between the most inshore of the banks, which rise to within $200 \mathrm{~m}$ of the sea surface. Using direct measurements from a Pegasus profiler near Cabo Frio $\left(23^{\circ} \mathrm{S}\right)$, EVANS and SigNORIN (1985) obtained evidence that nearly half of the current's southward transport of $11 \mathrm{~Sv}$ was inshore of the $200 \mathrm{~m}$ isobath. Satellite IR images of the region of $21^{\circ}-35^{\circ} \mathrm{S}$ (GARFIELD, 1988) show that the inshore edge of the Brazil Current is confined to regions less than $2000 \mathrm{~m}$ deep, with its mean position near the $200 \mathrm{~m}$ isobath also indicating that a significant portion of the current transport occurs over the continental shelf. As STRAMma (1989) pointed out, this may be why Fu (1981), who by using inverse techniques on the Meteor and IGY data, could find only a very marginal Brazil Current at $24^{\circ} \mathrm{S}$, and none at $16^{\circ} \mathrm{S}$.

Another feature revealed by satellite images along the Brazilian coast (GARFIELD, 1988) is the occurrence of a semi-permanent offshore meander in the vicinity of Cabo Sao Tome $\left(22^{\circ} \mathrm{S}\right)$ to Cabo Frio $\left(23^{\circ} \mathrm{S}\right)$, which may be related to the local upwelling described by MASCARENAS, MIRANDA and Rock (1971), IkEda, Miranda and Rock (1974) and Magliocca, Miranda and Signorini (1979). Although this feature was not evident in the survey by EVANS, SIGNORINI and MIRANDA (1983), its influence can be seen in the distributions of temperature at $50 \mathrm{~m}$ depth and surface dynamic topography in the data of SIGNORINI (1978).

As the Brazil Current flows south from $24^{\circ} \mathrm{S}$, it intensifies at a rate of about $5 \%$ per $100 \mathrm{~km}$ (GORDON and GREENGROvE, 1986), a grow th rate similar to that of the Gulf Stream though the actual transport values here are considerably less. South of about $30^{\circ} \mathrm{S}$, this downstream intensification appears to be linked to a recirculation cell which has been observed with hydrographic measurements (LENZ, 1975; REID, Nowlin and PATZERT, 1977; TsUCHIYA, 1985; GoRdon and GreEngrove, 1986; STRamma, 1989) and satellite IR imagery (Brown, Evans, Olson and Podesta, 1985) supplemented with drifter trajectories (Olson, Podesta, Evans and Brown, 1988). Because of the downstream growth of the Brazil Current, GoRDon and GREENGRove (1986) surmised that the recirculation cell carries about $12 \mathrm{~Sv}$ in the upper $1400 \mathrm{~m}$, and by closing off a region with hydrographic sections STRAMma (1989) estimated the geostrophic transport of the cell as being $7.5 \mathrm{~Sv}$ in the upper $800 \mathrm{~m}$ (relative to $1300-1600 \mathrm{~m}$ ), bringing the southward transport along the western boundary to nearly $18 \mathrm{~Sv}$ at $33^{\circ} \mathrm{S}$. Evidence for another recirculation cell in the western South Atlantic, north of $30^{\circ} \mathrm{S}$, was found by TsuchryA (1985) in historical data, and also with historical data REID (1989, his Fig.7) has observed a single, large recirculation cell at the surface extending from $20^{\circ}$ to $40^{\circ} \mathrm{S}$ in the western Atlantic. The poleward end of the cell fuels further growth for the Brazil Current, which attains transport values at $38^{\circ} \mathrm{S}$ of $19-22 \mathrm{~Sv}$ relative to 1400 1500m (Gordon and GreENGROVE, 1986; GoRdon, 1989; GARZOLI and GarRAFFo, 1989), where it then encounters the northward flow of the Falkland (Malvinas) Current and turns offshore.

All of the estimates discussed above for the geostrophic transport of the Brazil Current have been obtained by assuming levels-of-no-motion at shallow or intermediate depths. This procedure has not been seriously questioned for areas well north of where the Brazil Current turns 


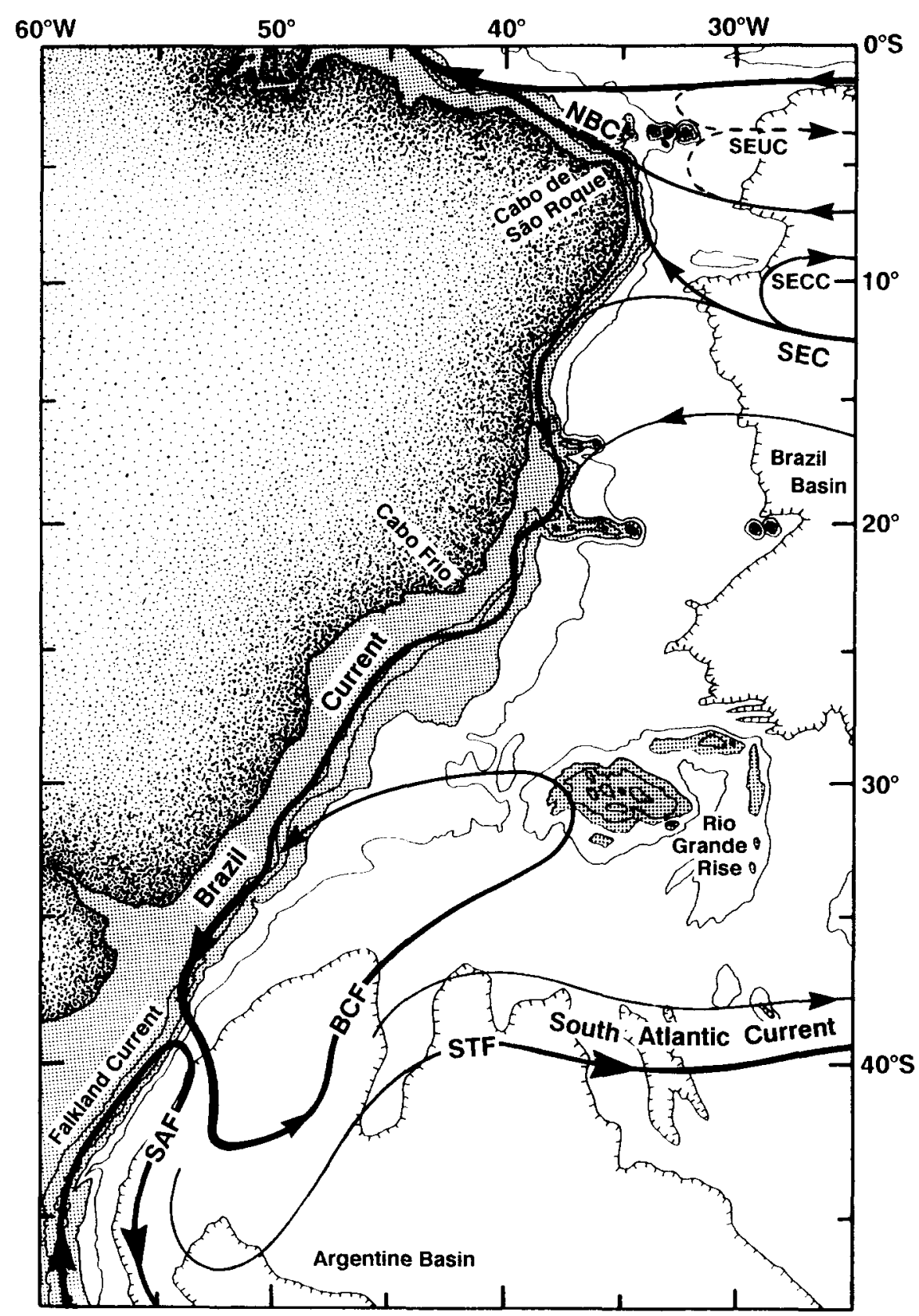

FIo. 18. Schematic illustration of the Brazil Current region. Abbreviated terms are: North Brazilian Current (NBC), South Equatorial Undercurrent (SEUC), South Equatorial Countercurrent (SECC), South Equatorial Current (SEC), Subantarctic Front (SAF), Brazil Current Front (BCF), and Subtropical Front (STF). Bathymetric contours are at $1000 \mathrm{~m}$ intervals; depths less than $3000 \mathrm{~m}$ are shaded. 
TABLE 2. Estimates of the southward transport of the Brazil Current obtained from in situ measurements. $1 \mathrm{~Sv}=10^{6} \mathrm{~m}^{3} \mathrm{~s}^{-1}$

\begin{tabular}{|c|c|c|c|c|c|}
\hline Author & Data & $\begin{array}{l}\text { Latitude } \\
\left({ }^{\circ} \mathrm{S}\right)\end{array}$ & $\begin{array}{l}\text { Reference } \\
\text { (m) }\end{array}$ & $\begin{array}{l}\text { Transport } \\
\text { (Sv) }\end{array}$ & Remarks \\
\hline $\begin{array}{l}\text { STRAMMA, IKEDA } \\
\text { and PETERSON (1990) }\end{array}$ & 13 historical sections & $10-20$ & $\sim 500$ & $0.8-6.0$ & average value near $4 \mathrm{~Sv}$ \\
\hline $\begin{array}{l}\text { Miranda and CASTRo } \\
\text { FLHO (1982) }\end{array}$ & Besnard, Sep-Oct 1967 & 19 & $\sim 500$ & 6.5 & \\
\hline \multirow{7}{*}{$\begin{array}{l}\text { Evans, SIGNORIN and } \\
\text { MiRANDA (1983) }\end{array}$} & Besnard, Apr 1982 & 19 & 500 & 5.3 & $\mathrm{XBT}^{\mathrm{a}}$ data $+\mathrm{T} / \mathrm{S}^{\mathrm{b}}$ \\
\hline & & 20.5 & 500 & 3.8 & \\
\hline & & & 1000 & 6.8 & \\
\hline & & 21.7 & 500 & 4.4 & $\mathrm{XBT}$ data $+\mathrm{T} / \mathrm{S}$ \\
\hline & & $23-25$ & 500 & 4.1 & \\
\hline & & & 1000 & 7.8 & \\
\hline & IGY, Apr-Jun 1959 & 32 & 1000 & 13 & \\
\hline $\begin{array}{l}\text { EVANS and SIGNORINI } \\
\text { (1985) }\end{array}$ & Oceanus, Apr 1983 & 23 & $\mathrm{DM}^{\mathrm{c}}$ & 11 & $\begin{array}{l}6 \mathrm{~Sv} \text { offshore of } 200 \mathrm{~m} \\
\text { isobath, } 5 \mathrm{~Sv} \text { inshore }\end{array}$ \\
\hline SIGNORINI (1978) & unspecified, Jul 1973 & $22-25$ & 600 & $6.8-9.4$ & \\
\hline \multirow[t]{5}{*}{ StRAMMA (1989) } & Oceanus, Feb 1983 & 23 & 600 & 10.2 & \\
\hline & & & 1300 & 11.0 & \\
\hline & Melville, Nov 1972 & 24 & $\begin{array}{c}600 \\
1300\end{array}$ & $\begin{array}{c}9.6 \\
10.2\end{array}$ & \\
\hline & Atlantis, Apr 1959 & 32 & $800-1600$ & 19.2 & $5.9 \mathrm{~Sv}$ in northward offshore \\
\hline & Melville, Nov 1972 & 33 & $800-1600$ & 17.5 & $\begin{array}{l}\text { includes an estimated } 5.3 \mathrm{~Sv} \\
\text { on the shelf }\end{array}$ \\
\hline \multirow[t]{2}{*}{ Fu (1981, Table 6) } & Meteor, 1925-1926 & $\sim 28$ & variable & 20 & $\begin{array}{l}\text { inverse calculation with } \\
\text { intermediate and upper deep } \\
\text { water contributions }\end{array}$ \\
\hline & IGY, 1958-1959 & $\sim 30$ & variable & 27 & \\
\hline EvaNS and MASCARENHAS & & 31 & $\mathrm{DM}^{\mathrm{c}}$ & 17 & $\begin{array}{l}\text { personal comment quoted by } \\
\text { GoRDON (1989) }\end{array}$ \\
\hline \multirow{2}{*}{$\begin{array}{l}\text { MCCARTNEY and ZEMBA, } \\
\text { (1988), and ZEMBA and } \\
\text { MCCARTNEY (1988) }\end{array}$} & Washington, & 27 & 600 & 9 & \\
\hline & Sep-Oct 1984 & 37 & 3000 & 76 & $\begin{array}{l}\text { includes contributions from } \\
\text { intermediate and deep } \\
\text { waters }\end{array}$ \\
\hline $\begin{array}{l}\text { GARZOLI and BIANCHI } \\
\text { (1987) }\end{array}$ & $\begin{array}{l}\text { inverted echo sounders, } \\
\text { Nov } 1984 \text { - Jun } 1985\end{array}$ & $37.5-38$ & 800 & $\begin{array}{l}10(\text { mean }) \\
23(\max )\end{array}$ & \\
\hline \multirow{5}{*}{$\begin{array}{l}\text { GARZOLI and GARRAFFO } \\
\text { (1989) }\end{array}$} & inverted echo sounders, & $37.5-38$ & 800 & 11 (mean) & \\
\hline & Jun 1985 - Mar 1986 & & 800 & $18(\max )$ & $\begin{array}{l}\text { includes part of the Falkland } \\
\text { Current return }\end{array}$ \\
\hline & & & 1400 & $22(\max )$ & $\begin{array}{l}\text { includes part of the Falkland } \\
\text { Current return }\end{array}$ \\
\hline & Balda, Jun 1985 & $37.5-38$ & 800 & 8.5 & \\
\hline & Balda, Mar 1986 & $37.5-38$ & 800 & 5.8 & $\begin{array}{l}\text { may be small due to an } \\
\text { inshore northward flow }\end{array}$ \\
\hline \multirow{2}{*}{$\begin{array}{l}\text { GORDON and GREENGROVE } \\
\text { (1986) }\end{array}$} & Atlantis II, & 38 & 1400 & 19.0 & \\
\hline & Dec 1979 - Jan 1980 & 42 & 1400 & 20.2 & $\begin{array}{l}\text { includes part of the Falkland } \\
\text { current return }\end{array}$ \\
\hline \multirow[t]{2}{*}{ GoRDON (1989) } & Washington, Oct 1984 & 38 & 1500 & 21.5 & \\
\hline & & 43 & 1500 & 22.5 & \\
\hline \multirow[t]{2}{*}{ Peterson (1990) } & $\begin{array}{l}\text { Atlantis II, } \\
\text { Dec } 1979 \text { - Jan } 1980\end{array}$ & 38 & variable & 70 & $\begin{array}{l}\text { includes contributions from } \\
\text { intermediate and deep }\end{array}$ \\
\hline & & & $(\sim 3000)$ & & waters \\
\hline ScHEMAINDA $(1980)$ & Haeckel, Jun-Jul 1978 & 42 & 800 & 18 & \\
\hline
\end{tabular}

"Expendable bathythermograph

'Temperature/salinity relations

'Direct measurements from a Pegasus profiler 
offshore, as it is fairly well accepted that the current is relatively shallow and remains close to the coast. But for the southern Brazil Current this has not been so unanimously accepted. On the basis of water mass characteristics (REID, Nowlin and PATZERT, 1977; GREENGROve, 1986; PETERSON and WHITWORTH, 1989; and RED, 1989), it appears that the southward flow in the region of the southern Brazil Current extends from the sea surface down through the North Atlantic Deep Water, to depths of $3000 \mathrm{~m}$ or more. Taking this into consideration, MCCARTNEY and ZEMBA (1988) and ZEMBA and MCCARTNEY (1988) have estimated the total southward geostrophic transport across $37^{\circ} \mathrm{S}$ in the region of the offshore-turning Brazil Current as $76 \mathrm{~Sv}$ relative to $3000 \mathrm{~m}$. PETERSON (1990) obtained a comparable value of $70 \mathrm{~Sv}$ at $38^{\circ} \mathrm{S}$ using a similar deep reference level.

Satellite IR images taken over a period of about 3 years (July 1984 to June 1987) show that the point at which the Brazil Current separates from the continental shelf ( $1000 \mathrm{~m}$ isobath) varies from $33^{\circ}$ to $38^{\circ} \mathrm{S}$, with the average being near $36^{\circ} \mathrm{S}$ and probably not related to the local winds (Orson, PoDESTA, Evans and Brown, 1988). This variability is corroborated by time-series of the dynamic height of the sea surface relative to $800 \mathrm{dbar}$ obtained from an array of inverted echo sounders moored in the confluence zone during 1984-1986 (GARzoli and GarRAFFo, 1989). Though the available data are not yet sufficient to statistically establish whether there is any seasonality in the point of separation, an analysis of satellite IR images taken during the period of January 1980 to March 1981 indicates that the front separating Brazil Current water from subantarctic water is farther offshore (and hence the separation point farther north) during the austral winter and spring than it is during summer and fall (GoDol, 1982). Further work based on IR images by OLSON, PODESTA, EvANS and BROWN (1988) also reveals a more northerly separation point during winter than summer. The mechanisms responsible for this apparent seasonality are not known, but one might speculate on the relations of this with the seasonality elsewhere in the South Atlantic. As compared with the austral summer situations, those in winter (pointed out in previous sections) include the subtropical high pressure system being centered farther north with a higher central pressure, while the South Equatorial Current is also farther north and is stronger. In addition, the zero-line of wind stress curl which extends across the southern South Atlantic in winter lies approximately $5^{\circ}$ north of its summer position(Fig.8 in Olson, Podesta, Evans and Brown, 1988), all of these together suggest that the subtropical gyre may shift northward during the winter, with one manifestation being the apparent seasonality in the separation point of the Brazil Current.

After separating from the western boundary, the Brazil Current continues to flow in a general southward direction for some distance together with the return flow of the Falkland Current; the Brazil Current component of this confluence was estimated by GoRDON (1989) as being 22.5Sv relative to $1500 \mathrm{~m}$ at $43^{\circ} \mathrm{S}$, which is near the most southerly positions attainable by the current before it turns east and north. The southern limit to the warm water bounded by the Brazil Current has been observed in satellite IR images to fluctuate between $38^{\circ}$ and $46^{\circ} \mathrm{S}$ over time scales of about two months (LEGECKIS and GoRDON, 1982). The bi-monthly southward excursions of the Brazil Current are analogous to the semi-periodic westward penetrations of the Agulhas Current into the Atlantic which occur over similar time scales (Section 3.1).

GoRDON (1981) has noted that enhanced ocean-to-atmosphere heat fluxes should be expected in the southward extension of thermocline water, and by using temperature and salinity measurements from the region he gave evidence that convective processes occurring in the poleward loop of the Brazil Current are important in ventilating the main thermocline farther north. Figure 19 provides an example of the poleward loop of the Brazil Current with a salinity field at $100 \mathrm{~m}$ depth constructed from observations made during four different research cruises. The contours can be loosely regarded as being parallel to the flow. The salty $(>36)$ core of the 
Brazil Current is observed near the continental slope north of about $38^{\circ} \mathrm{S}$, whereupon the current separates from the western boundary at its confluence with the northward-flowing Falkland Current to lose heat and salt through tubulent mixing with the cooler and fresher water of subantarctic origins. Also shown in the figure are the positions of the Subantarctic and Polar fronts according to PETERSON and WhTTORTH (1989) (to be discussed in Section 4.1), poleward of which are increasingly cold and fresh upper-layer water masses. The confluence of subtropical and subpolar waters extends southward to approximately $46^{\circ} \mathrm{S}$, before the poleward-flowing thermocline water executes a large anti-cyclonic return to the north. Because this return flow appears to be closing back on its source flow near $42^{\circ} \mathrm{S}$, a maximum southward excursion of the Brazil Current had probably taken place. As with the westward penetrations of the Agulhas Current, maximum southward extensions of the Brazil Current are followed by the shedding of warm-core, but less energetic eddies which are lost to the Subantarctic Zone of the Antarctic Circumpolar Current. In comparison with the large (320km diameter), single eddies shed from each pulse of the Agulhas Retroflection, those formed during northward retreats of the Brazil Current, as observed in satellite IR images (LEGECKIs and GORDON, 1982), are smaller (averaging about 150km across) and more numerous (formation rate of about one per week), though their azimuthal surface speeds nearing 80 $\mathrm{cm} \mathrm{s}^{-1}$ (OLSON, GORDON and HOOKER, 1985; GORDON, 1989) are similar. Unfortunately, the relatively coarse station grid in Fig. 19 does not allow for such a pattern to be well resolved. A volume transport of about $20 \mathrm{~Sv}$ around a newly-formed Brazil Current eddy near $44^{\circ} \mathrm{S}$ was obtained by Gordon (1989), which is just half that of an Agulhas equivalent.

Aside from the transport estimates pertaining to the total southward flow, which contain contributions from the deep circulation (Table 2), all other estimates of the Brazil Current transport based on hydrographic data are considerably less than those predicted from fields of wind stress. An analytic wind-driven model with simplified geometry was used by VERONIS (1973) to calculate a maximum Brazil Current transport of $38 \mathrm{~Sv}$ at $36^{\circ} \mathrm{S}$, whereas HeLLERMAN and RoSENSTEIN (1983) used the homogeneous Sverdrup relation to obtain an annual mean transport of $30 \mathrm{~Sv}$ at $30^{\circ} \mathrm{S}$. Including bottom topography and a thermohaline component in a wind-driven numerical model, Mellor, Mechoso and Keto (1982, their Fig.11) obtained, without comment, a transport for the Brazil Current of more than $60 \mathrm{~Sv}$. This value compares with the $52 \mathrm{~Sv}$ estimated by VERONIS (1978) from his wind-driven analytic model modified to include thermohaline forcing. VERONS (1973) thought that intense mixing at the Brazil-Falkland Confluence Zone might be one factor contributing to the weakness of the Brazil Current, whereas another factor to consider is whether or not the Benguela Current absorbs some of the transport from the interior. But STOMMEL (1957) had earlier proposed that the Brazil Current is weaker than expected from the wind fields because of an opposing effect of the thermohaline circulation, which in the North Atlantic involves the formation and sinking of North Atlantic Deep Water. His view is supported by a salinity budget for the Atlantic (GoRDON and PIOLA, 1983) in which the formation of North Atlantic Deep Water requires a net transfer of thermocline water from the South Atlantic to the North, together with net northward fluxes of intermediate and bottom waters (RINTOUL, 1990). These results are consistent with observations showing that the surface circulation of the South Atlantic subtropical gyre is not a closed system, but is one where most of the transport of its northern limb is lost to the equatorial countercurrents and to the northern hemisphere (STRAmMA, IKEDA and PETERSON, 1990). Without this loss, the Brazil Current would no doubt be significantly stronger. GoRdon and GREENGROve (1986) have pointed out that the deficit in the Brazil Current transport relative to Sverdrup-type solutions might be compensated by the deep western boundary current which carries North Atlantic Deep Water toward the south. 


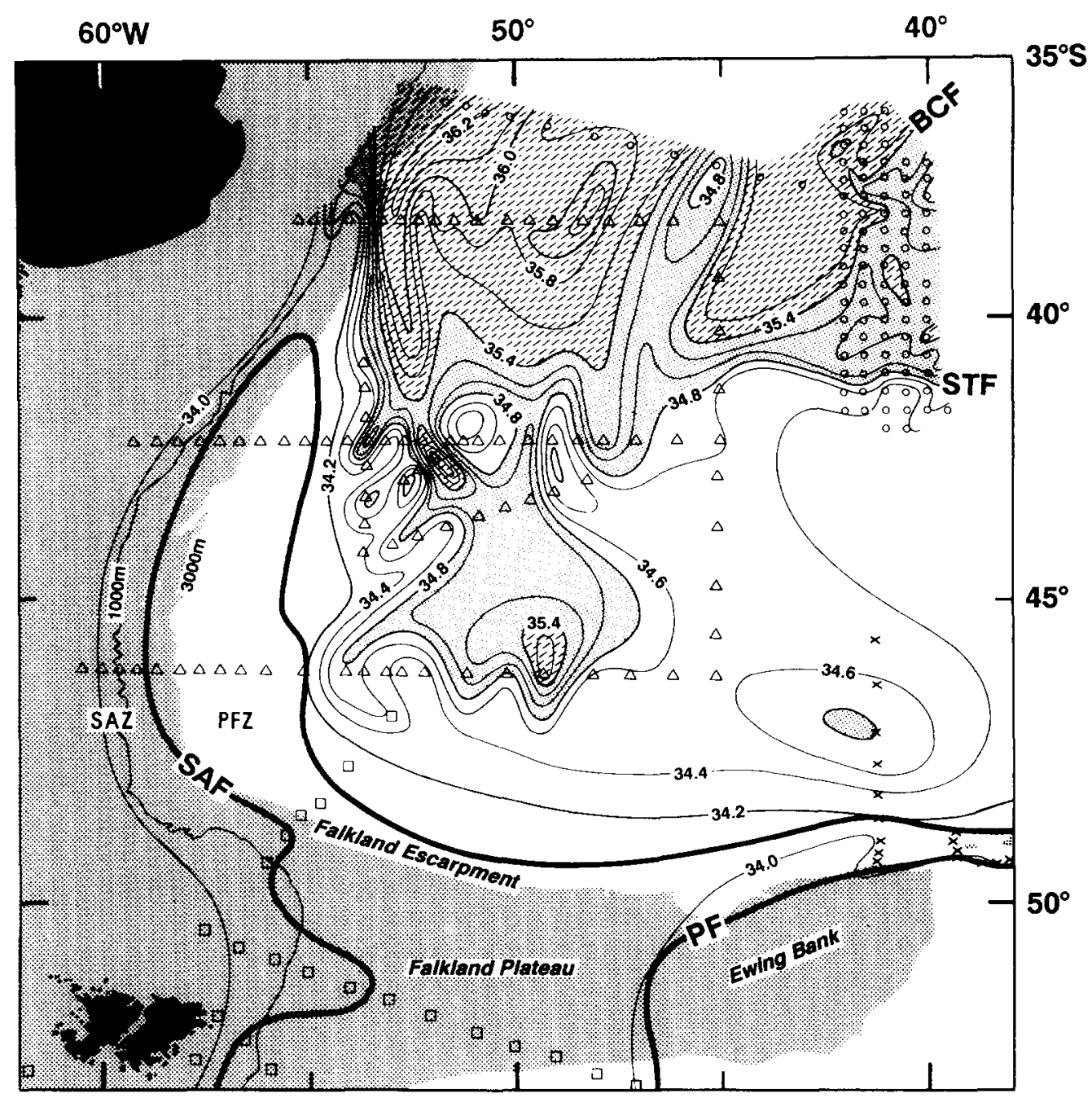

Fig. 19. Distribution of salinity at 100-m depth in the southwestern South Atlantic as constructed from bottle samples taken during the following four cruises: Atlantis II cruise 107 leg III (triangles); Atlantis II cruise 107 leg X (squares); Thomas Washington Marathon Expedition leg 8 (circles); and Robert D. Conrad cruise 28-03 (crosses) (STRAMma and PETERson, 1990). Also indicated are the Subantarctic Zone (SAZ), Polar Frontal Zone (PFZ), Subantarctic Front (SAF), and PolarFront (PF) after PETERSON and WHTTWORTH (1989).

\subsection{South Atlantic Current}

The circulation of the South Atlantic subtropical grye is closed in the south by the South Atlantic Current (SAC). This current is analogous to the North Atlantic Current (for information see Krauss, 1986) in that it is the seaward extension of that part of the western boundary current which does not enter the subtropical recirculation near the American shelf. The SAC is distinct from the Antarctic Circumpolar Current, and is separated from it by the Subtropical Front (STF) (STRAMma and Peterson, 1990). 
3.5.1. Subtropical Front. The STF was identified by KRÜMMEL (1882) as being a sharp discontinuity in surface temperature which he found to stretch across most of the South Atlantic from its origins in the Brazil-Falkland Confluence Zone. DEACON (1933) later studied this discontinuity in greater detail, referring to it as the Subtropical Convergence, and observed sudden changes in surface temperature and salinity of at least $4^{\circ} \mathrm{C}$ and 0.5 , respectively, as the discontinuity is crossed. He traced its position across the South Atlantic, finding that it lies for the most part $2^{\circ}$ or $3^{\circ}$ north of $40^{\circ} \mathrm{S}$ except near $30^{\circ} \mathrm{W}$ and south of Africa where it is south of that latitude. According to DeACON (1937), the surface waters just north of the front have minimum temperatures ranging from $11.5^{\circ} \mathrm{C}$ in winter to $14.5^{\circ} \mathrm{C}$ in summer, and are often warmer by $5^{\circ} \mathrm{C}$ or more, and that they have salinities of at least 34.9. Progressing northward from the front, both mean temperature and mean salinity continue to increase, until temperatures of nearly $28^{\circ} \mathrm{C}$ are reached at the equator during southern summer (HöFLICH, 1984) and annual-mean salinities in excess of 37.25 are reached near $15^{\circ} \mathrm{S}$ (TCHERNIA, 1980).

DEACON's $(1933 ; 1937)$ generalizations of the temperature and salinity changes taking place across the discontinuity have been widely accepted, though the name he used for this frontal feature has been an occassional point of contention. Early on, BöHNECKE (1936) and others held that the term Subtropical Convergence should be reserved for a wind-driven surface convergence at $30^{\circ}-35^{\circ} \mathrm{S}$, but this objection was not widely endorsed and the terminology used by DeAcon has been almost universally followed until late. In locating thermostads beneath the seasonal thermocline around the southern hemisphere, MCCARTNEY (1977) envisaged a continuity of those in the southwestern Atlantic with others found in the Indian and Pacific oceans. The thermostads in the Atlantic were found to be just north of DEACON's convergence, whereas other but colder thermostads were found north of the Subantarctic Front in the other sectors of the Antarctic Circumpolar Current. Because of the apparent continuity of all the thermostads observed, and, in retrospect, probably because there was very little information about the Subantarctic Front in the South Atlantic downstream of Drake Passage, McCARTNEY (1977) argued that a single, circumpolar front resides along the poleward sides of these deeply-mixed layers, and he referred to it as the Subantarctic Front. The Subantarctic Front is now thought to be circumpolar in extent, but it is not connected with what has been popularly called the Subtropical Convergence, a feature which does not go through Drake Passage. But other authors (RoDEN, 1986; 1989; Olson, PodEstA, EVANS and BRown, 1988) have followed MCCARTNEY's (1977) South Atlantic terminology, and while these are exceptions to the rule, the results they have presented need to be integrated into the whole and thus the inconsistencies in terminology clarified. Finally, to avoid implications regarding the type of motion involved, the term Subtropical Convergence has recently been modified by a few authors to Subtropical Front (for example, HoFManN, 1985; WHITWORTH and NowLL, 1987), and we adopt this terminology.

Because the STF is the poleward boundary to the warm and salty thermocline waters of the subtropical gyre, and because no subtropical waters are found in Drake Passage, the STF by definition must get its start at the western boundary with the confluence of the Brazil and Falkland currents. But the points at which the surface fronts associated with these two currents separate from the western boundary (the $1000 \mathrm{~m}$ isobath) are usually not coincident. On the basis of satellite IR images, Olson, Podesta, Evans and Brown (1988) observed an intervening zone up to $300 \mathrm{~km}$ wide populated with eddies which separates the two seaward-turning fronts and which can be traced as a continuous feature into the ocean interior. Inspection of their Fig. 7 reveals that when averaged over a period of nearly three years the seaward extension of Brazil Current water (identified by the $21^{\circ} \mathrm{C}$ isotherm) reaches $40^{\circ}-42^{\circ} \mathrm{W}$ at a latitude of about $37^{\circ} \mathrm{S}$, and that subantarctic water (identified by the $16^{\circ} \mathrm{C}$ isotherm) reaches the same longitudes at $41^{\circ}-42^{\circ} \mathrm{S}$. 
Figure 1 in the paper by GoRDON and GREENGROve (1986) shows that during the early austral summer the $16^{\circ} \mathrm{C}$ isotherm is representative of the warmest subantarctic waters found in the confluence zone, and should therefore be a close indicator of the STF. The seaward locations for the two fronts as revealed from the satellite survey agree well with the positions of two fronts observed earlier by RODEN (1986) in a closely-spaced hydrographic survey (shown as the open circles in Fig.19). But the surface temperatures in the fronts observed at sea were about $5^{\circ} \mathrm{C}$ less than in the satellite survey, presumably because the ship-board measurements were made in the austral spring (October-November), when sea surface temperatures are near their annual minima; whereas the identifiers used in the satellite survey remained unchanged with season. The seagoing survey measured temperatures and salinities at the southern front which were consistent with the classical definitions of the STF, but in both papers (RodEN, 1986; Olson, Podesta, Evans and BROWN, 1988), and in a third (RODEN, 1989), this feature was referred to as the Subantarctic Front.

The salinity and temperature changes across the STF compensate one another in the density field, resulting in weak baroclinic shears of horizontal velocity in the upper mixed layer (RODEN, 1986; WHITWORTH and NowLIN, 1987). But this is not the case with the northern of the two fronts, which RoDEN (1986) referred to as the Brazil Current Front (BCF). According to him, the BCF is characterized by sharp thermohaline gradients in the upper $500 \mathrm{~m}$ and large vertical shears of horizontal velocity. As can be inferred from Fig.19, however, the two fronts do not remain distinctly separated once they first diverge from one another near the western boundary. In the west, the STF extends southward to around $46^{\circ} \mathrm{S}$ with the poleward extension of thermocline water, whereas if the 35.4 isohaline is used as a rough indicator, the BCF appears to remain north of $42^{\circ} \mathrm{S}$. There are then a pair of regions where meanders bring the two fronts into close proximity before they separate perhaps for the final time near $42^{\circ} \mathrm{W}$. The mean course of the $\mathrm{BCF}$ is not established, but it is likely to continue around the recirculation cell of very warm and salty surface waters in the Argentine Basin similar to the way the upper-level flow fields in the region have been depicted by REID, Nowlin and PATzert (1977) and STRAMma (1989). Circumstantial evidence for this is that no front resembling the BCF has been documented in the central and eastern portions of the subtropical gyre.

3.5.2. Geostrophic flow. The zonal current associated with the STF, the South Atlantic Current, is understood in only the most general ways. Stramma and PeTERson (1990) observed the SAC to be an identifiable eastward current band flowing mainly along, and just to the north of, the STF. The surface speeds of the SAC are not large when compared with those of the Brazil or Agulhas currents or those associated with the fronts within the circumpolar current, which is a result of the opposing effects of the distributions of temperature and salinity in the density field near the STF. Surface velocities of the SAC are apparently at their largest in the Argentine Basin, where they are on the order of $20 \mathrm{~cm} \mathrm{~s}^{-1}$ (RODEN, 1986) to $27 \mathrm{~cm} \mathrm{~s}^{-1}$ (STRAMMA and PETERSON, 1990), before decreasing to values only half as large in the Cape Basin (WHITWORTH and NowLIN, 1987; Stramma and Peterson, 1990). Volume transport of this current follows the same trend; in the Argentine Basin it is typically $30 \mathrm{~Sv}$ in the upper $1000 \mathrm{~m}$ relative to about $3000 \mathrm{~m}$, reaching values as high as 37Sv, whereas in the Cape Basin it is only about 15Sv (STRAMmA and Peterson, 1990).

The transport values of $30 \mathrm{~Sv}$ and more for the SAC in the Argentine Basin are comparable to, and even larger than, those of the Brazil (without deep contributions) and Benguela currents. But details concerning the eastward attrition of the SAC are not available. As STRAMMA and PETERSON (1990) have pointed out, the hydrographic data base near $40^{\circ} \mathrm{S}$ between $25^{\circ} \mathrm{W}$ and the Greenwich Meridian is extremely paltry, making it impossible to judge what effects the mid-ocean ridge might have on the transport of the SAC. In the western basin the deeper waters move in the same 
general direction as the near-surface waters (REID, NowLIN and PATZERT, 1977), whereas in the eastern basin there seems to be very little zonal flow at all at large depth beneath the STF (Whitworth and Nowlin, 1987; Stramma and Peterson, 1990). Given similar baroclinic structures in the upper layers, the transport of the SAC should be less in the eastern basin than in the west, because of the differences in the deeper flow, and this is evidently the case. But the available data are too few to test whether there is a marked reduction as the current flows over the mid-ocean ridge, or whether the flow gradually stems off to the interior of the subtropical gyre.

As the weakened SAC flows east, it enters the eddy-filled region of the Agulhas Current Retroflection and is strongly influenced by it. Instead of continuing east with the STF south of Africa, the SAC turns north to feed the Benguela Current. Why the SAC should separate from the STF is not entirely clear, or even if it does so all the time, but it seems that the saltiness of the Indian Ocean Central Water is of primary importance. In the region southwest of a newly-shed Agulhas eddy, Stramma and Peterson (1990) calculated a volume transport at the STF of nearly $10 \mathrm{~Sv}$ in the upper $1000 \mathrm{~m}$ toward the northwest, which is in the opposite direction relative to the front as is the usual case. The cause of this was deemed to be the presence of very strong horizontal salinity gradients which over-compensated the thermal effects in the density field, and this was completely consistent with requirements for mass balance in the region. Shown in Fig. 20 is their field of geostrophic volume transport in the upper $1000 \mathrm{~m}$ in a region southwest of southern Africa. The flow into the region across these two quasi-synoptic sections amounts to about $26 \mathrm{~Sv}$, with the only possible outlet being toward the north. The $17 \mathrm{~Sv}$ flow of the SAC near the prime meridian can not continue east with the STF, but must turn north, which would be consistent with the transport of the Benguela Current across a line closing the triangular region to the north as determined by Stramma and Peterson (1989). Being joined by about $8 \mathrm{~Sv}$ of Agulhas Current water, this turn of the SAC into the Benguela Current provides the southeastern closure of the South Atlantic subtropical gyre.

\section{ANTARCTIC CIRCUMPOLAR CURRENT}

In this section we give a short overview of the observed zonation and volume transport of the Antarctic Circumpolar Current (ACC) in the South Atlantic. For an in-depth treatment of mesoscale variability, meridional exchanges, and theories and models for the current as a whole, the reader is referred to the comprehensive review by NowLIN and KLINCK (1986). Additional information concerning deep water masses and stratification of the ACC can be found in the papers by Sievers and Nowlin (1984) (Drake Passage), Peterson and Whitworth (1989) (southwestern Atlantic), and WHITwORTH and NowLIN (1987) (Greenwich Meridian).

\subsection{Zonation}

The ACC has been studied in greatest detail in Drake Passage, particularly during the mid1970 s to the early 1980 s with the implementation of the International Southern Ocean Studies (ISOS) program. Results from the ISOS investigations have shown the ACC to be strongly banded in the velocity field, which is illustrated in Fig.21. Shown in the figure are verticallyaveraged geostrophic speeds in the upper $2500 \mathrm{~m}$ (relative to $2500 \mathrm{~m}$ ) normal to a line of stations spanning Drake Passage. The zonal jets and bands of relative quiescence for which the ACC is now well known are clear. Near the terminus of South America is the Subantarctic Zone (SAZ), which, at locations other than Drake Passage, is bounded to the north by the STF. Southward from the SAZ are the Subantarctic Front (SAF), Polar Frontal Zone (PFZ), Polar Front (PF), Antarctic Zone (AZ), Continental Water Boundary (CWB), and Continental Zone (CZ). At the narrow 


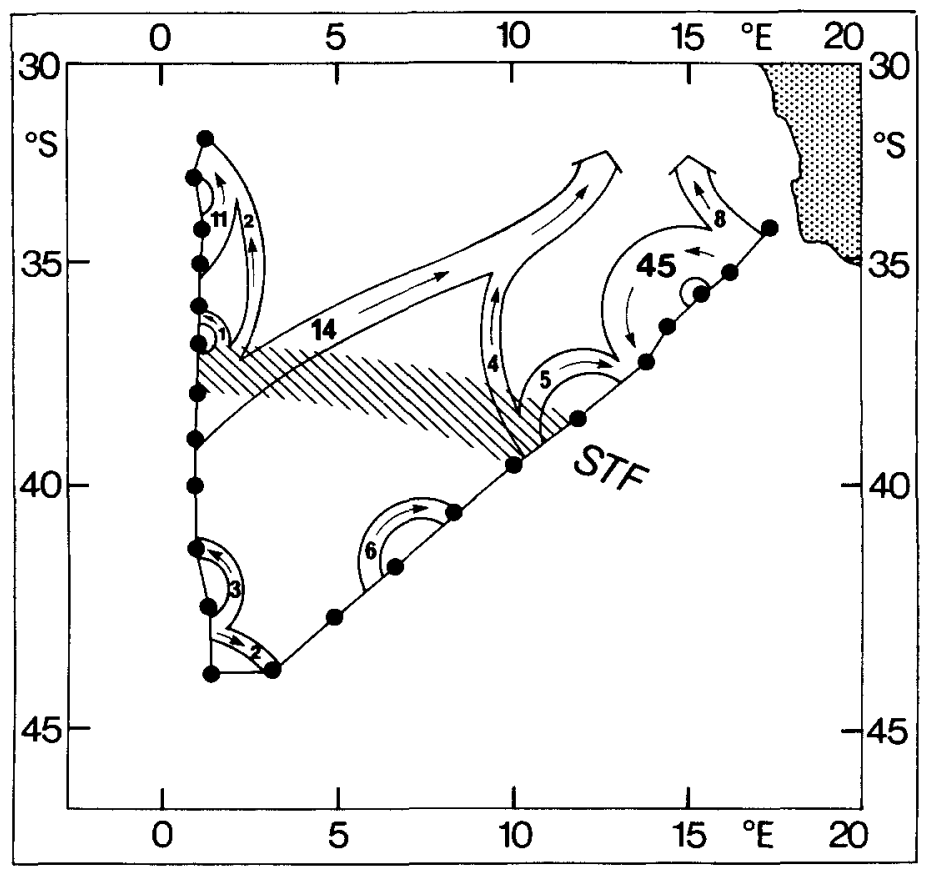

FIG. 20. Field of geostrophic volume transport (Sv) in the upper $1000 \mathrm{~m}$ relative to the potential density surface of $\sigma_{0}=45.87 \mathrm{~kg} \mathrm{~m}^{-3}$ in the region enclosed by two sections made by the R/V Knorr in October and November 1983 (Stramma and Peterson, 1990). Except for the coastal stations, the reference level lies in the depth range of $3350-3730 \mathrm{~m}$.

fronts, the vertically-averaged through-passage speeds are in the range of $12-17 \mathrm{~cm} \mathrm{~s}^{-1}$, and, except near the South American continent where the landmass may act to constrict the flow, there are much weaker speeds in the water mass zones. NowLIN and CLIFFORD (1982) have observed typical upper-level geostrophic speeds (relative to $2500 \mathrm{~m}$ ) in Drake Passage to be $30-45 \mathrm{~cm} \mathrm{~s}^{-1}$ at the SAF and PF, and $15-30 \mathrm{~cm} \mathrm{~s}^{-1}$ at the CWB. They also found that the three fronts account for threequarters of the through-passage geostrophic transport, but, while being on the order of $40-60 \mathrm{~km}$ wide apiece, together occupy only one-fifth of the width of the passage.

First evidence for the banding of the ACC came with observations by ScHoTT (1902) of sharp changes in surface temperature and salinity occurring between Antarctic and subantarctic waters southwest of Africa and north of Kerguelan. MenARDus (1923) traced the approximate course of that hydrographic boundary from the eastern Pacific to the mid Indian Ocean, a course later referred to by Schort (1926) as the "Meinardus Line," by Defant (1928) and Wüst (1928) as the "Oceanic Polar Front," by DEACON (1933) as the "Antarctic Convergence," and by WYRTKI (1960) as the "Antarctic Polar Front." The simplified term "Polar Front" (PF) has come into widespread usage as it makes no implications about relative motions at the boundary, which have been thought to be possibly divergent (WEXIER, 1959).

Hydrographically, the PF is the northern boundary to cold $\left(-1.5^{\circ}\right.$ to $\left.2^{\circ} \mathrm{C}\right)$ near-surface water formed by winter cooling (MosBy, 1934). Beneath this Antarctic Surface Water is the relativelywarm and homogeneous Circumpolar Deep Water. During summer, the Antarctic Surface Water 


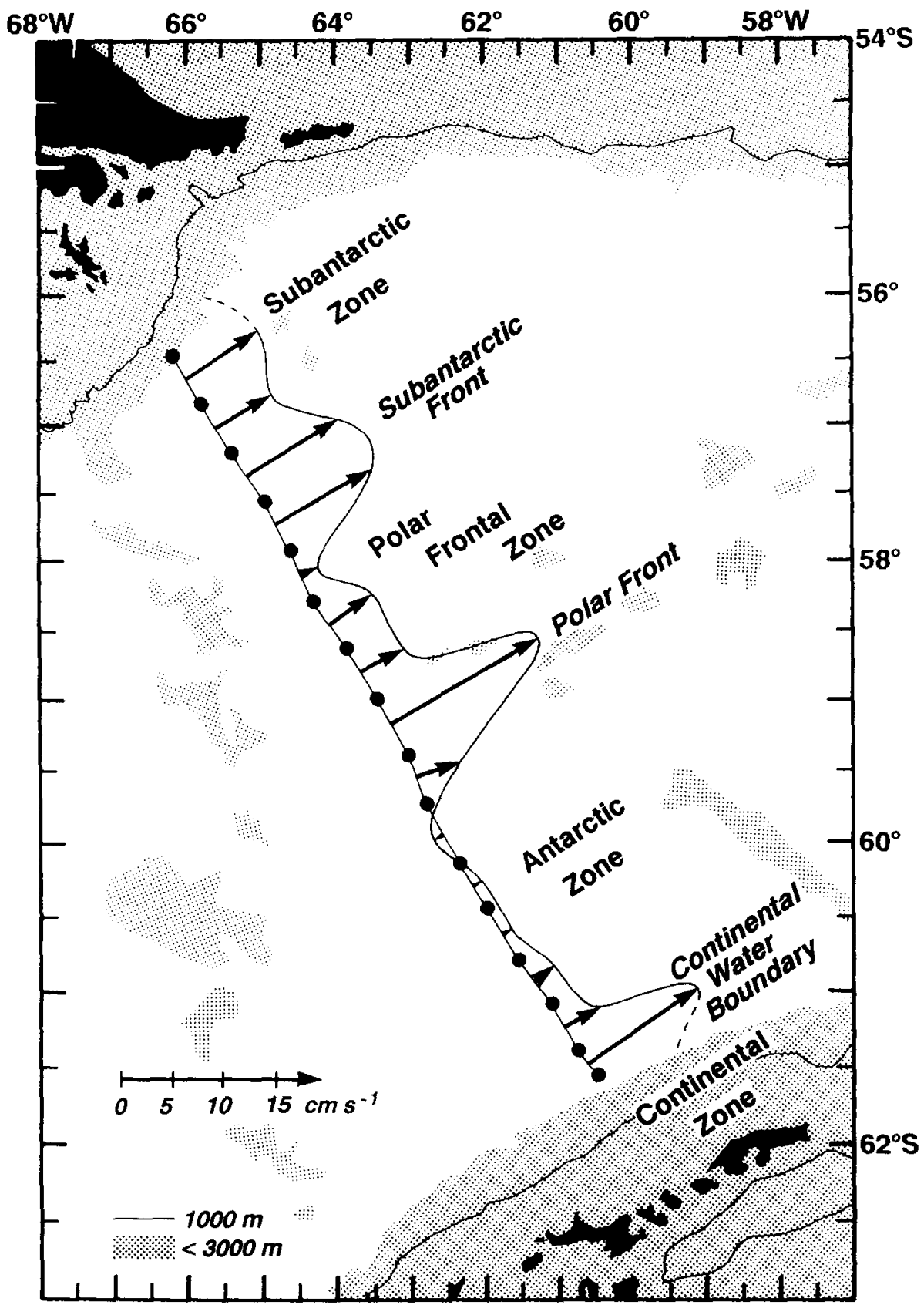

Fig. 21. Vertically-averaged geostrophic speeds in the upper $2500 \mathrm{~m}$, relative to $2500 \mathrm{~m}$, normal to a line of stations occupied by R/V Thompson during 28 February - 3 March 1976 (adapted from Peterson, Nowlin and WhTTWORTH, 1982). 
is overlain by a seasonally warmed surface layer, thereby leading to the appearance of an upperlayer temperature minimum. The temperature minimum is embedded in a strong halocline in the upper $200 \mathrm{~m}$ and is generally colder than $0^{\circ} \mathrm{C}$, except near or at the PF where it warms and deepens northward along inclined isopycnals. When subsurface temperature measurements were available to them, DEACON (1933) and MACKnNTOSH (1946) fixed the position of the PF as to where the temperature minimum sinks below $200 \mathrm{~m}$, which was modified by GoRDON (1967) to where the temperature minimum makes a rapid northward descent. Nowlin, WHTTWORTH and PILLSBURY (1977) used the northern extent of the $0^{\circ} \mathrm{C}$ isotherm associated with the temperature-minimum layer as an indicator for the location of the $\mathrm{PF}$, a variation from the widely-used northern extent of the $2^{\circ} \mathrm{C}$ isotherm near $200 \mathrm{~m}$ depth (BotnIKov, 1963). Although the various indicators provide locations for the PF that are often in close agreement, PETERSON and WHITWORTH (1989) argued in favor of the criterion proposed by DEACON (1933). But these subsurface indicators yield positions for the PF which are for the most part not identical with those of the most intense surface temperature gradients. In the region south of Africa,LUTJEHARMS and VALENTINE(1984) have found that in $75 \%$ of the cases the subsurface expression for the PF is north of the surface front, with the distance between the two being as large as $300 \mathrm{~km}$.

Additional banding of the ACC was first noted by DeACoN (1937) when he observed internal isopleths of temperature and salinity rising toward the south across the current in a series of steps; but an explicit account of a second front in the ACC was not given until BuRLING (1961) observed two types of subantarctic water between the Polar Front and Subtropical Front in the region from southern New Zealand to Macquarie Island. He called the boundary between the two subantarctic water masses the "Australasian Subantarctic Front," and observed that it extends from the sea surface to depths of more than $1000 \mathrm{~m}$. OsTAPOFF (1962) soon after applied a frictional, diagnostic model to the zonal geostrophic velocities obtained from a line of widely-spaced hydrographic stations along the Greenwich Meridian to predict the existence of a narrow zone of upward motion some $5^{\circ}$ or $6^{\circ}$ latitude north of the Polar Front. He called the northern feature the "Subantarctic Front" and drew comparisons between it and the front described by BuRLING (1961). Also south of New Zealand, GoRDON (1967) found the Polar Front to occupy a complex zone of mixing $2^{\circ}$ $4^{\circ}$ latitude wide. Arguing that the Polar Front is probably not a distinct line, Gordon, TAYLOR and Georgi (1974) used the term "Polar Front Zone," the northern boundary to which was near Burling's (1961) Australasian Subantarctic Front. Gordon, GeORGI and TaYLoR (1977) found similar complexity in defining the Polar Front in the Scotia Sea, maintaining that it would be better considered a zone, and not a line, in that region as well. Their Polar Front Zone was described as being limited to the north by a subantarctic boundary and to the south by an Antarctic one, with each being near an axis of the ACC. Consistent with this were findings by NowLIN, WHITWORTH and Pllssbury (1977) within Drake Passage of a vertically-coherent band of relatively large eastward velocity at each of these boundaries of the "Polar Frontal Zone" (PFZ), a region of transition between Antarctic and Subantarctic surface waters. This eddy-populated region of transition was studied from south of Australia to Drake Passage by EMERY (1977) and was seen to be a continuous feature of variable width. He suggested calling the southern boundary, which was the same as had been tradionally known as the Polar Front, the "Antarctic Front," and proposed that the northern boundary, the same as that described by BuRLING (1961), be simply called the "Subantarctic Front" (SAF). This meaning for the SAF, i.e., that it is the hydrographic boundary between the PFZ and the SAZ, has since been adopted by investigators working in Drake Passage (Whitworth, 1980; PetErson, Nowlin and WhITwORTH, 1982; Nowlin and Clifford, 1982; and several others), in the southwestern Atlantic (PETERSON and WhrTwORTH, 1989), at the Greenwich Meridian (WhrTworth and NowlIN, 1987), south of Africa (LuTJEHARMS and 
VALENTINE, 1984), south of New Zealand (HEATH, 1981), and along the entire length of the ACC as well (CLIFFORD, 1983; HoFMANN, 1985). As was previously discussed (section 3.5.1), this term has been used on occasion in a different sense, i.e., for what we have called the STF in the southwestern Atlantic.

A third front exists within Drake Passage, the Continental Water Boundary. This term was introduced by SIEVERS and EMERY (1978) to demarcate the northern limit of a cold water mass (colder than about $0^{\circ} \mathrm{C}$ ) near the South Shetland Islands having a subsurface isothermal layer extending from about $150 \mathrm{~m}$ depth to more than $500 \mathrm{~m}$. This feature was earlier described by DEACON (1933) as separating water of Bellingshausen Sea origin (west of Drake Passage) from that of the Weddell Sea. The influence of Bellingshausen Sea water decreases toward the east in southern Drake Passage (GoRDon and NowlIN, 1978), but recent work by SMrTH (1989) has shown that the Continental Water Boundary remains a continuous feature into the southern Scotia Sea where it forms the northern limit to the Weddell-Scotia Confluence. GoRDon (1967) described the confluence as being a zone of discontinuity between deep water masses originating from the southeast Pacific Ocean and Weddell Sea. He suggested that it might extend as far east as $30^{\circ} \mathrm{E}$. SMTTH (1989) referred to the northern boundary of the Weddell-Scotia Confluence as the Scotia Front, and the poleward boundary in the northwestern Weddell Sea as the Weddell Front (refer to Fig.1). He also presented evidence that in addition to it being an extension of the Continental Water Boundary from Drake Passage, the Scotia Front is also continuous with the ACC-Weddell Gyre Boundary observed at the Greenwich Meridian by WHITwORTH and NowLIN (1987). We do not describe this frontal feature in any detail here. For further information concerning the hydrography of this boundary, and of the deep-reaching vertical convection and mixing processes occurring near it, the reader is referred to DEACon and MOOREY (1975), DEACON and FosTER (1977), PATtERSON and Sievers (1980), and Bersch and Becker (1986) and SMITH (1989).

The spatial orientation of the Polar Front in the South Atlantic was described by DeAcon (1933) and again in more detail by MAckinTosh (1946). In both cases, the positions of the front were established on the basis of sea surface temperature, and when available, the location at which the temperature-minimum of Antarctic Surface Water sinks below $200 \mathrm{~m}$ depth. Shown in Fig. 22 is the well-known map constructed by Mackintosh (1946). As he pointed out, the Polar Front executes a large S-shaped turn between the Falkland Islands and South Georgia, much like that drawn by Deacon (1933). According to Mackintosh's Table 9, most of the frontal positions in that region were based on surface temperature, and it is in that region where DEACON (1933) found the two methods for fixing the Polar Front to agree the least. He noted that while the surface conditions there are often subantarctic, and probably only temporary, Antarctic water appears only $100 \mathrm{~m}$ below the surface. GORDON, GEORGI and TAYLOR (1977) confirmed the great complexity of the region with a hydrographic and XBT survey of the western Scotia Sea. They found their Polar Front Zone as describing a course similar to the envelope of PF positions depicted in MACKINTOSH's map. More recently, PETERSON and WHITWORTH (1989) used observations from two cruises in the southern Argentine and northern Georgia basins to find the PF at $49^{\circ}-50^{\circ} \mathrm{S}$ between $35^{\circ}$ and $40^{\circ} \mathrm{W}$ (that portion of Fig. 1 is based on their observations), which is on the order of $200 \mathrm{~km}$ north of the course largely based on surface temperatures depicted by MAckINTOSH. The difference is probably caused by subantarctic water overriding Antarctic water. Shown in Fig. 23 is a vertical section of temperature along a short line of closely-spaced XBT stations made in the southern Argentine Basin. As depicted in the inset, the section began on the Falkland Ridge and extended north across another narrow ridge and into the Argentine Basin. The temperatureminimum of Antarctic water is clear at the stations south of the crest of the northern ridge, whereas the surface temperature front normally associated with the PF is somewhere south of the section 
and well south of the subsurface front. The coincidence of the subsurface expression of the PF and the crest of the northern ridge was a recurring observation, as was the close proximity of the PF with the SAF in the region (PETERSON and WHTTWORTH, 1989). At locations farther east in the South Atlantic, the two fronts are separate features. The PF has recently been found in much the same positions as described by DEACON (1933) and MACKINTOSH (1946); at both the Greenwich Meridian (WHITWORTH and NowLIN, 1987) and south of Africa (LUTJEHARMS, 1985) the PF is near $50^{\circ} \mathrm{S}$.

The course of the SAF has been studied to a much lesser extent than that of the PF, which is partly because the SAF is not always clear in the surface temperature fields; it is better identified with upper-layer salinities. North of the front, the SAZ is characterized by weak vertical gradients of salinity in the upper layer that overlay a weak maximum, which in turn is found above the salinity minimum of the Antarctic Intermediate Water. Well north of the SAF, the salinity minimum of Antarctic Intermediate Water typically resides near the potential density surface of $\sigma_{0}=27.2 \mathrm{~kg} \mathrm{~m}^{-3}$ at depths of $500-1000 \mathrm{~m}$. In the southern $\mathrm{SAZ}$, this minimum rises rapidly southward along tilted isopycnals into the $\mathrm{SAF}$, and approaches or reaches the sea surface within the PFZ. The rapid northward descent of the salinity minimum of Antarctic Intermediate Water is also evident where BuRLING (1961, his Figs.9 and 11) found his Australasian SAF south of New Zealand, though he identified the front there more in terms of absolute values of upper-level salinity, such as those less than 34.5 being south of the front.

Although the SAF is less recognizable in the temperature field than in the salinity, it seems to coincide well with enhanced subsurface horizontal temperature gradients between the $3^{\circ}$ and $5^{\circ} \mathrm{C}$ isotherms (SIEVERS and EMERY, 1978; LUTJEHARMS and VALENTINE, 1984) and can be located reasonably well by the $4^{\circ} \mathrm{C}$ isotherm at $200 \mathrm{~m}$ depth in the southwestern Atlantic (PETERSON and WHITWORTH, 1989). Shown in Fig. 24 is a field of the depth of the $4^{\circ} \mathrm{C}$ isotherm as observed during late winter conditions in the region of the Falkland Current. On the basis of this field alone, the SAF appears to turn sharply northward east of Drake Passage, following the Patagonian shelf to the Brazil-Falkland Confluence Zone at about $40^{\circ} \mathrm{S}$ whereupon it retroflects back toward the south before making an eastward turn in the southern Argentine Basin. Vertical sections of salinity, oxygen, and nutrients confirm such a course, not only in the survey depicted, but in another during summer conditions in the western Argentine Basin (Peterson and WhITworth, 1989). Temperature-salinity relations and horizontal distributions of density also show the thermohaline structure within the cyclonic trough of the Falkland Current as being similar to the water mass zonation observed in northern Drake Passage (PIOLA and Gordon, 1989).

Transport estimates for the Falkland Current have been relatively few. ZYRYANOv and SEvEROV (1979) used historical density fields in a multi-level, diagnostic numerical model to calculate depth-integrated transports of the Falkland Current at $45^{\circ} \mathrm{S}$ to be $32 \mathrm{~Sv}$ during the southern summer and $40 \mathrm{~Sv}$ in winter, noting that a large cyclonic flow field exists to the east of the northward-flowing current. Using a reference level of $1400 \mathrm{~m}$, GORDON and GREENGROVE (1986) obtained northward transports of 9.8 and $11.4 \mathrm{~Sv}$ at $42^{\circ} \mathrm{S}$ and $46^{\circ} \mathrm{S}$, respectively. But because their surface geostrophic velocities $\left(17 \mathrm{~cm} \mathrm{~s}^{-1}\right)$ in the Falkland Current were only half those of a pair of surface drifters that traversed the same region, they concluded that non-zero bottom velocities must exist and that their estimates represent lower limits. PIOLA and BIANCHI (1990) used a number of hydrographic sections made in the years since 1980 and found the Falkland Current transport to range only between 10 and $12 \mathrm{~Sv}$ relative to $1000 \mathrm{~m}$. This result indicates that the internal distribution of density in the current does not change appreciably, however, the absolute Falkland Current transport is probably quite a lot higher. Characteristics of water masses at depth indicate that the northward flow off the Patagonian shelf extends from the sea surface to the bottom (REID, 


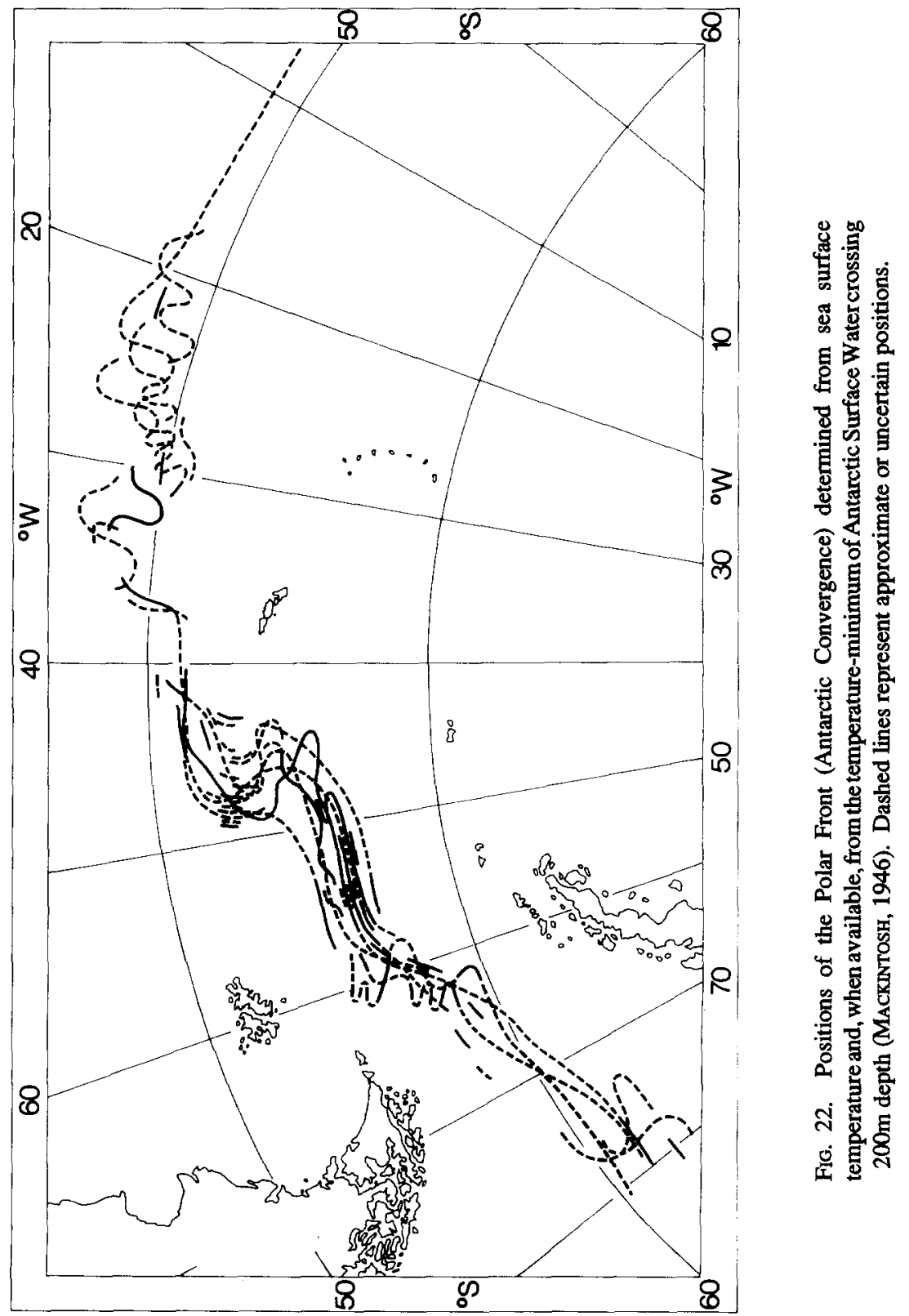




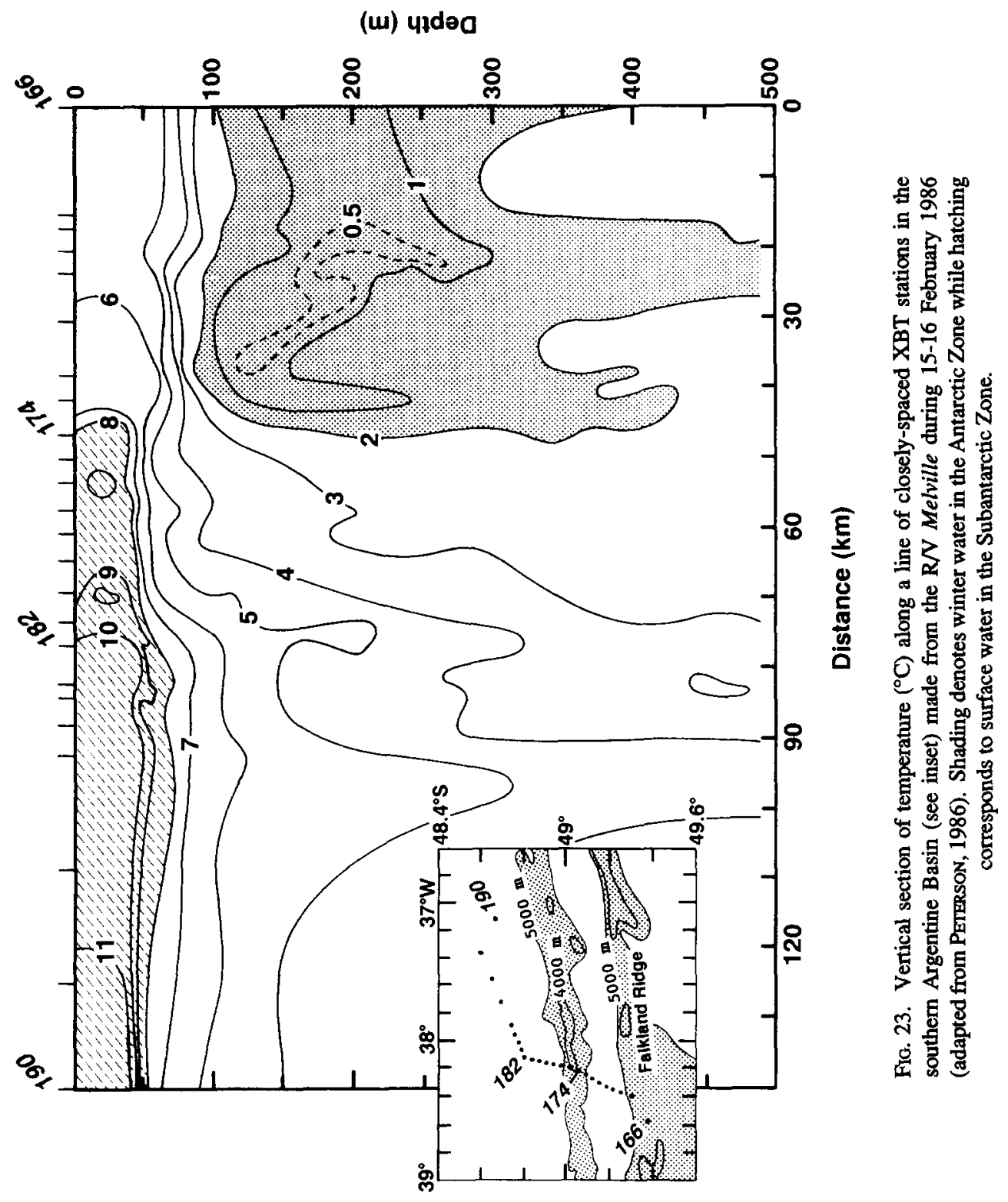

JPO 26:1-C 


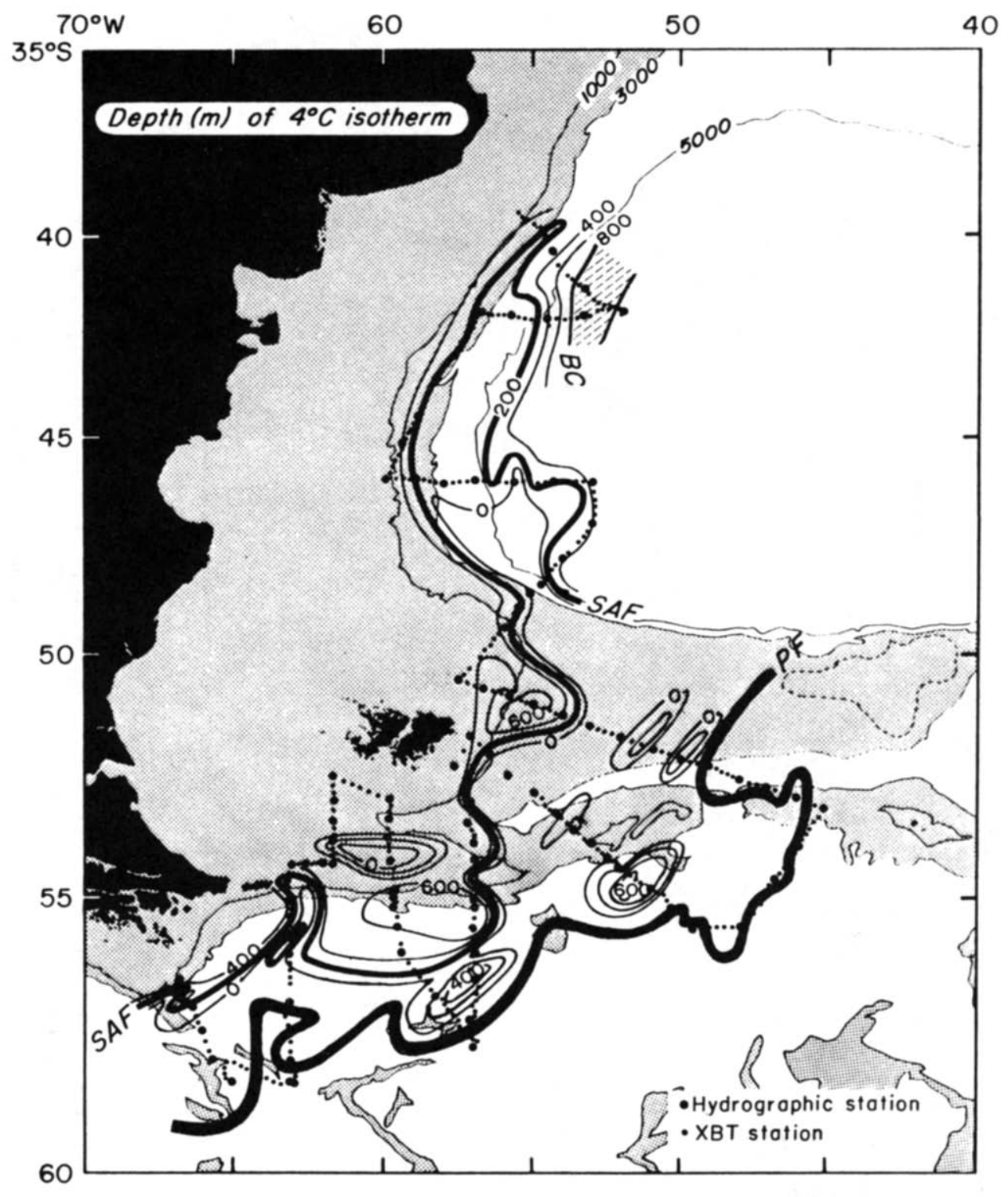

Fic. 24. Depth of the $4^{\circ} \mathrm{C}$ isotherm (m) observed from the $\mathrm{R} / \mathrm{V}$ Atlantis $I I$ during the austral winter of 1980 (adapted from PETERSON and WHTTWORTH, 1989). The course of the Subantarctic Front (SAF) is approximated by the $200 \mathrm{~m}$ contour, while the Polar Front (PF) is depicted with the heaviest line.

The hatched area represents central water bounded by the Brazil Current (BC). 
Nowlin and PAtzert, 1977; Greengrove, 1986; Peterson and WhItworTh, 1989; Reid, 1989), which makes a compelling case that a significant barotropic component exists in the Falkland Current which can not be accounted for by choosing an arbitrary reference level. By using a quasisynoptic, full-depth hydrographic survey enclosing the Brazil-Falkland Confluence Zone, Peterson (1990) estimated that the depth-integrated absolute northward transport of the Falkland Current is approximately $70 \mathrm{~Sv}$ at $42^{\circ} \mathrm{S}$. This estimate was arrived at as a residual quantity required to get mass balances in several isopycnic layers once the Brazil Current transport had been solved on the basis of water mass characteristics. This estimate is much larger than any previous ones for the Falkland Current, but was not thought to be unreasonable in light of the eastward flow from the SAF and northwards in Drake Passage turning north over the Falkland Plateau $(\sim 2500 \mathrm{~m}$ sill depth) and into the Falkland Current subsequently to override abyssal flow also moving north. The deeper flow in Drake Passage associated with the SAF, continues east into the Georgia Basin before entering the Argentine Basin through deep breaks in the bathymetry (WHITWORTH and NowLIN, 1990).

Just north of the SAF in the southeastern Pacific, the coldest variety of Subantarctic Mode Water (SAMW) is formed in late winter by deep $(400-600 \mathrm{~m})$ convection and is advected through Drake Passage into the western South Atlantic (MCCARTNEY, 1977). But how much of this gets into the South Atlantic is not known. In studying upper-level modal salinity and density characteristics around Antarctica, PiolA and GeORGi (1982) concluded that relatively little of the southeast Pacific SAMW is advected through Drake Passage. Qualitatively, this is consistent with Fig.24 in which only a few isolated pools of nearly isothermal $\left(\sim 4.5^{\circ} \mathrm{C}\right)$ and isohaline $(34.0-34.2)$ water (reaching from the surface to as deep as $700 \mathrm{~m}$ ) are seen to occur both north and south of the SAF. SAMW might be supplied to the South Atlantic only through episodic events.

At the poleward end of the eddy field generated by the confluence of the Brazil and Falkland Currents is a surface temperature front, characterized by temperatures of $10^{\circ}-12^{\circ} \mathrm{C}$ at $30 \mathrm{~m}$ depth; this was described by IKEDA, SIEDLER and ZwIERZ (1989) as the Falkland Escarpment Front. They found it to be very closely pinned to the southern edge of the Argentine Basin (during the austral summer) between $50^{\circ}$ and $55^{\circ} \mathrm{W}$ in several north-south XBT sections made near the western boundary. This locates their front at nearly the same place as where the SAF turns eastward after returning to the south from the Brazil-Falkland Confluence Zone, but the relation between the two fronts is unclear as the spatial extent and temporal permanence of the Falkland Escarpment Front await further investigations.

Eastward from the narrow neck formed by its northward and return branches in the southwestern Argentine Basin, Peterson and WhITwORTH (1989) observed the SAF to coincide with the northern side of the Falkland Plateau, and that in the region of the Ewing Bank the SAF can at times merge with the PF. The combined horizontal density gradients of the two fronts were observed to produce an intense eastward jet having surface geostrophic speeds of $80 \mathrm{~cm} \mathrm{~s}^{-1}$ and more, or twice the speeds associated with the individual fronts in Drake Passage. North of the Islas Orcadas Rise and to the east, the two fronts were observed once again to be distinct. At both the Greenwich Meridian (WHITWORTH and Nowlin, 1987) and south of Africa (LuTJEHARMs, 1985), the SAF lies some $500 \mathrm{~km}$ north of the Polar Front.

\subsection{Volume transport}

The volume transport of the $\mathrm{ACC}$ has been a point of contention since the first estimate was given by CLowes (1933). He argued that the eastward flow of the ACC through Drake Passage extends to great depth and that no water from the Atlantic passes westward into the Pacific. On the basis of hydrographic stations made during 1929-1930 from ships of the Discovery expedi- 
tions, he arrived at a volume transport of $110 \mathrm{~Sv}$, or about 4 times that of the Florida Current. Several other estimates have been made since then based on a variety of techniques and these are summarized in Table 3. As listed, the estimates of volume transport through Drake Passage obtained from in situ measurements range from more than $200 \mathrm{~Sv}$ eastward, to flow in the opposite direction. Much of the disparity comes from using the equivalent barotropic assumption and in adjusting geostrophic shears to direct measurements in a streaky and highly variable current system.

TABLE 3. Estimates of the eastward volume transport of the Antarctic Circumpolar Current through Drake Passage obtained from in situ measurements (after PETERson, 1988a)

\begin{tabular}{|c|c|c|c|c|}
\hline Author & Data & Reference & $\begin{array}{l}\text { Transport } \\
\left(10^{6} \mathrm{~m}^{3} \mathrm{~s}^{-1}\right)\end{array}$ & Remarks \\
\hline Clowes (1933) & $\begin{array}{l}\text { Discovery expeditions, } \\
1929-1930\end{array}$ & 3500dbar & 110 & non-sysnoptic \\
\hline $\begin{array}{l}\text { SVERDRUP, JoHNSON and } \\
\text { FLEMING (1942) }\end{array}$ & composite & $3000 \mathrm{dbar}$ & 90 & transport function \\
\hline KORT (1959) & $O b$, Jun 1958 & $\begin{array}{l}3000 \mathrm{~m} \\
\text { bottom }\end{array}$ & $\begin{array}{l}134 \\
165\end{array}$ & $\begin{array}{l}\text { not verifiable } e^{a, b} \\
\text { not verifiable } e^{n, b}\end{array}$ \\
\hline EsKIN (1959) & $O b$, Jun 1958 & $3500 \mathrm{~m}$ & 141 & not verifiable ${ }^{b}$ \\
\hline OSTAPOFF (1960) & Discovery II, Apr 1930 & variable & 0 & Defant $^{c}+$ EBA \\
\hline OSTAPOFF (1951) & Discovery II, Apr 1930 & $\begin{array}{l}\text { variable } \\
2000 \mathrm{dbar} \\
3000 \mathrm{dbar}\end{array}$ & $\begin{array}{l}-1 \\
33 \\
85\end{array}$ & Defant + EBA \\
\hline & $O b$, Jun 1958 & $\begin{array}{c}\text { variable } \\
2000 \mathrm{dbar} \\
3000 \mathrm{dbar}\end{array}$ & $\begin{array}{c}9 \\
34 \\
86\end{array}$ & Defant + EBA \\
\hline $\begin{array}{l}\text { YOROB 'YEV and GINDYSH } \\
(1965)\end{array}$ & $\begin{array}{l}\text { composite, summer } \\
\text { composite, winter }\end{array}$ & $\begin{array}{l}\text { variable } \\
\text { variable }\end{array}$ & $\begin{array}{l}119 \\
91\end{array}$ & $\begin{array}{l}\text { Defant } \\
\text { Defant }\end{array}$ \\
\hline GORDON (1967) & $O b$, Jun 1958 & variable & 218 & $\mathrm{~T} / \mathrm{S}+\mathrm{EBA}$ \\
\hline \multirow[t]{4}{*}{ REID and Nowlin (1971) } & Washington, Jan 1969 & $\begin{array}{c}3000 \mathrm{dbar} \\
3500 \mathrm{dbar} \\
\text { bottom } \\
\text { variable }\end{array}$ & $\begin{array}{l}103 \\
113 \\
113 \\
237\end{array}$ & $\begin{array}{l}\text { relative to } 6 \text { CMRs } \\
300 \mathrm{~m} \text { above bottom }\end{array}$ \\
\hline & Discovery II, Apr 1930 & $\begin{array}{c}3000 \mathrm{dbar} \\
3500 \mathrm{dbar} \\
\text { bottom }\end{array}$ & $\begin{array}{l}84 \\
92 \\
92\end{array}$ & \\
\hline & Discovery II, Mar 1934 & $\begin{array}{c}3000 \mathrm{dbar} \\
3500 \mathrm{dbar} \\
\text { bottom }\end{array}$ & $\begin{array}{c}88 \\
105 \\
117\end{array}$ & \\
\hline & $O b$, Jun 1958 & $\begin{array}{c}3000 \mathrm{dbar} \\
3500 \mathrm{dbar} \\
\text { bottom }\end{array}$ & $\begin{array}{c}87 \\
108 \\
113\end{array}$ & \\
\hline FOSTER (1972) & Hudson, Feb 1970 & variable & $\begin{array}{l}-5 \\
-15\end{array}$ & $\begin{array}{l}\text { Defant + EBA } \\
\text { relative to } 12 \text { CMRs } \\
\text { from } 4 \text { moorings }\end{array}$ \\
\hline
\end{tabular}




\begin{tabular}{|c|c|c|c|c|}
\hline Author & Data & Reference & $\begin{array}{l}\text { Transport } \\
\left(10^{6} \mathrm{~m}^{3} \mathrm{~s}^{-1}\right)\end{array}$ & Remarks \\
\hline \multirow[t]{3}{*}{$\begin{array}{l}\text { NOWLIN, WHITWORTH and } \\
\text { PLLLSBURY (1977) }\end{array}$} & Melville, Feb-Mar 1975 & $\begin{array}{l}3000 \mathrm{dbar} \\
\text { variable }\end{array}$ & $\begin{array}{c}95 \\
124\end{array}$ & $\begin{array}{l}5 \text {-section average } \\
\text { relative to CMRs, } \\
\text { several moorings }\end{array}$ \\
\hline & Thompson, Mar 1976 & 3000dbar & 110 & \\
\hline & Hudson, Feb 1970 & $3000 \mathrm{dbar}$ & 75 & \\
\hline $\begin{array}{l}\text { BRYDEN and PILLSBURY } \\
\text { (1977) }\end{array}$ & ISOS, Mar-Oct 1975 & $\sim 2700 \mathrm{~m}$ & $\begin{array}{l}\text { mean: } 39^{d} \\
\text { range: } 220\end{array}$ & $\begin{array}{l}\text { barotropic only, } \\
\text { relative to } 6 \text { CMRs }\end{array}$ \\
\hline \multirow[t]{3}{*}{ WHTTWORTH (1980) } & 16 summer sections & $\begin{array}{l}2500 \mathrm{dbar} \\
2500 \mathrm{dbar}\end{array}$ & $\begin{array}{c}79 \pm 13 \\
81 \pm 8\end{array}$ & transport function \\
\hline & 6 winter sections & $2500 \mathrm{dbar}$ & $71 \pm 15$ & \\
\hline & & $2500 \mathrm{dbar}$ & $74 \pm 15$ & transport function \\
\hline \multirow[t]{2}{*}{ LUTJEHARMS (1982) } & composite & $3000 \mathrm{~m}$ & $\sim 200$ & trans.fun. $\left(45^{\circ} \mathrm{S}\right)$ \\
\hline & & $3000 \mathrm{~m}$ & -160 & trans.fun. $\left(60^{\circ} S\right)$ \\
\hline \multirow{5}{*}{$\begin{array}{l}\text { NoWLIN and CLIFFoRD } \\
(1982)\end{array}$} & Thompson, Feb 1976 & $2500 \mathrm{~m}$ & 88 & \\
\hline & Thompson, Feb-Mar 1976 & $2500 \mathrm{~m}$ & 88 & \\
\hline & Melville, Feb-Mar 1975 & $2500 \mathrm{~m}$ & 87 & \\
\hline & Melville, Mar 1975 & $2500 \mathrm{~m}$ & 86 & \\
\hline & Atlantis II, Jan-Feb 1980 & $2500 \mathrm{~m}$ & 88 & \\
\hline \multirow{7}{*}{$\begin{array}{l}\text { WHTTWORTH, NOWLIN and } \\
\text { WORLEY (1982) }\end{array}$} & Melville, Jan-Feb 1977 & $3000 \mathrm{dbar}$ & 75 & \\
\hline & Melville, Jan-Feb 1979 & $3000 \mathrm{dbar}$ & 110 & \\
\hline & Yelcho, Apr-May 1979 & $3000 \mathrm{dbar}$ & 102 & \\
\hline & Atlantis II, Jan-Feb 1980 & $3000 \mathrm{dbar}$ & 105 & \\
\hline & Melville, Jan-Feb 1979 & variable & 117 & $\begin{array}{l}\text { relative to CMRs, } \\
\text { several moorings }\end{array}$ \\
\hline & Yelcho, Apr-May 1979 & variable & 144 & $\begin{array}{l}\text { relative to CMRs, } \\
\text { several moorings }\end{array}$ \\
\hline & Atlantis II, Jan-Feb 1980 & variable & 137 & $\begin{array}{l}\text { relative to CMRs, } \\
\text { several moorings }\end{array}$ \\
\hline WHTTORTH (1983) & $\begin{array}{l}\text { ISOS, } \\
\text { Jan 1979-Feb } 1980\end{array}$ & speed at $500 \mathrm{~m}$ & $\begin{array}{l}\text { mean: } 12^{e} \\
\text { range: } 61\end{array}$ & in upper $2500 \mathrm{~m}$ \\
\hline $\begin{array}{l}\text { WHITWORTH and } \\
\text { PETERSON (1985) }\end{array}$ & $\begin{array}{l}\text { 500m pressures, } \\
\text { Jan } 1977-F e b 1980 \text { and } \\
\text { Mar 1981-Mar } 1982\end{array}$ & - & $\begin{array}{l}\text { mean: } 123 \\
\text { range: } 63\end{array}$ & $\begin{array}{l}\text { in upper } 2500 \mathrm{~m} \text {, from } \\
\text { a regression } \\
\text { model using across- } \\
\text { passage pressure } \\
\text { differences only }\end{array}$ \\
\hline
\end{tabular}

EBA - equivalent barotropic assumption

$\mathrm{T} / \mathrm{S}$ - temperature/salinity relation, used to identify deep countercurrent in southem Drake Passage (GoRDoN, 1966)

CMR - current meter record

ISOS - Intemational Southern Ocean Studies

- Noted by Ostaporf (1961)

' Noted by ReID and Nowlan (1971)

' Defant's method used for determining reference level

${ }^{d}$ Authors suggest adding $100 \mathrm{~Sv}$ for total transport

- Revised value given by Whtrworth and PEIERSON 
Resolution of the banding of the ACC was a key goal of the ISOS program, which culminated with the deployment of an extensive array of moored instruments across Drake Passage during the year 1979. In addition to much information regarding the space and time scales of current variability (see Nowlin and KLINCK, 1986 for review), it was learned that while most of the ACC transport is in the baroclinic field, the transport fluctuations are mainly barotropic (WHITWORTH and PETERSON, 1985). This is consistent with REID and Nowl (1971) who had earlier pointed out that the internal pressure field is relatively steady and that the various hydrographic sections yield similar transports when treated in the same manner. Referring to Table 3, WHITwORTH (1980) observed the baroclinic volume transport relative to $2500 \mathrm{dbar}$ across 16 summer sections to average about $80 \mathrm{~Sv}$ with standard deviations of $10 \%-15 \%$ of the mean value. In five summer sections, NowLIN and CLIFFORD (1982) obtained transports relative to $2500 \mathrm{~m}$ ranging from 86 to just $88 \mathrm{~Sv}$. Relative to $3000 \mathrm{dbar}$, there are 12 independent and verifiable, quasi-synoptic estimates that average $93 \mathrm{~Sv}$ and range from 75 to $110 \mathrm{~Sv}$. Relative to the bottom, there are four such estimates averaging $109 \mathrm{~Sv}$ and ranging from 92 to $117 \mathrm{~Sv}$.

The baroclinic component of variability is comparatively small, which allowed WHrTwORTH and PETERSon (1985) to use multi-year records of bottom pressure at each side of Drake Passage to estimate variations in volume transport over longer time intervals than otherwise possible. Their time series of volume transport in the upper $2500 \mathrm{~m}$ is shown in Fig. 25 , obtained from acrosspassage differences of bottom pressure at $500 \mathrm{~m}$ depth. The mean value, $123 \mathrm{~Sv}$, was set equal to that of a time series of net transport through the passage during 1979 which was computed with additional information (Whitworth, 1983; WhITworth and Peterson, 1985). In Fig.25 it is of particular interest to note that transport fluctuations of nearly half the mean value can occur over periods as short as two weeks (July 1978 and June-July 1981), and that there is no interannual phase relationship in the seasonal variations. Much longer time series are needed for a better understanding of transport fluctuations occurring over seasonal and longer time scales, but unfortunately, an attempt to extend the bottom pressure series through the use of coastal sea level records spanning two decades and more from each side of Drake Passage was not successful (PETERSON, 1988b).

There have been only a few attempts to relate transport fluctuations of the ACC with the overlying wind fields. VAN LOON (1972) adjusted monthly mean sea level differences across Drake Passage with atmospheric sea level pressure, finding that the semi-annual oscillation in the slope of the sea surface is inconsistent in phase with that of the local eastward surface winds. WEARN and BAKER (1980), however, obtained high coefficients of correlation (0.6) between two years of bottom pressure differences across Drake Passage at $500 \mathrm{~m}$ depth, smoothed with a 28 day running mean filter, and zonally-averaged eastward wind stress in the latitude band of $40^{\circ}$ $65^{\circ} \mathrm{S}$. As they pointed out, their high correlations were entirely the result of the agreement between bottom pressure at the southern side of the passage and the wind stress fields. Pressure at the northern side was poorly correlated with wind. Chelton (1982) noted that their high correlations might have resulted merely from both series containing strong seasonal signals. Using a yearlong time series of transport through Drake Passage based on records obtained from an extensive array of moored instruments, WHITWORTH (1983) found only a narrow band of periods (16-24 days) where transport and zonally-averaged eastward wind stress were coherent at the $95 \%$ confidence level.

The spectral composition of each the baroclinic and barotropic components of transport variability at Drake Passage was analyzed by PETERson (1988a). It was found that transport variability occurring over subseasonal time scales, as measured by moored instruments at each 


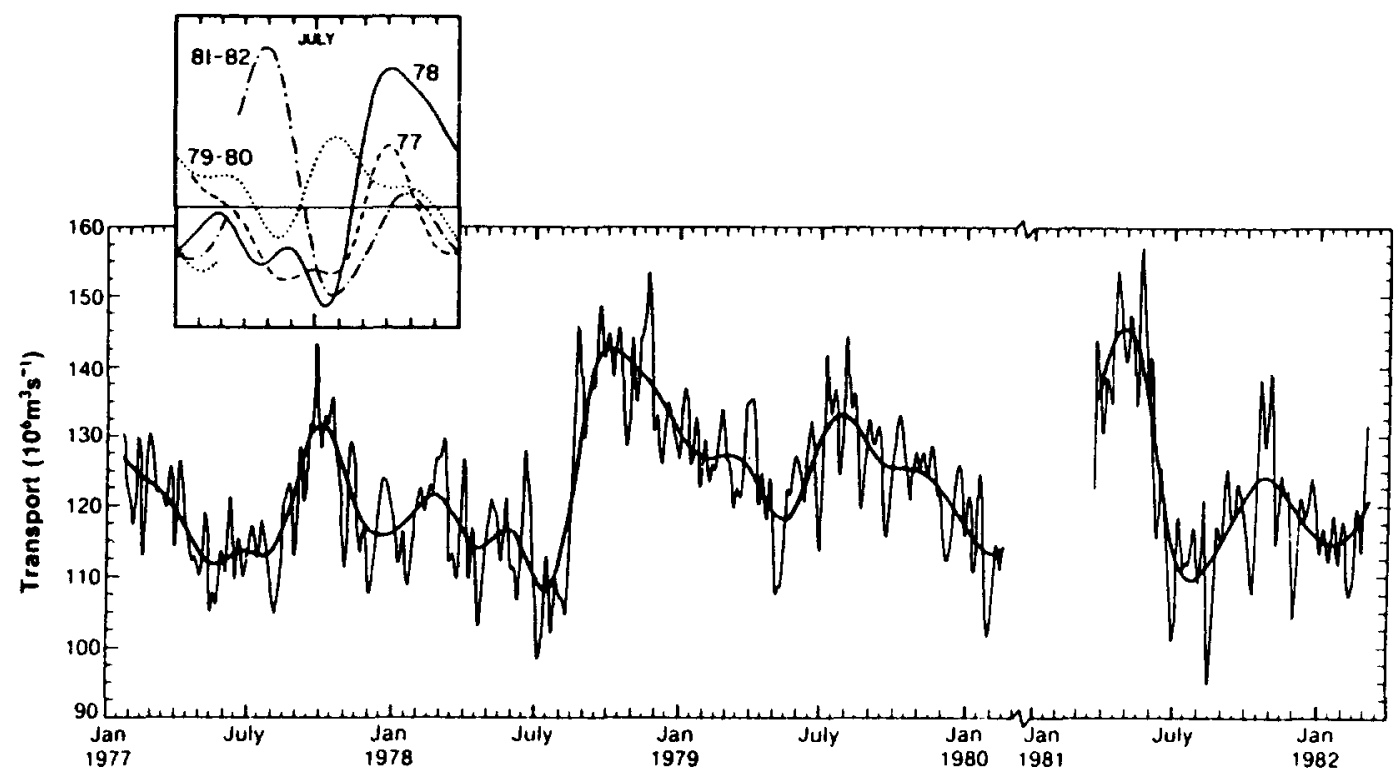

Fig. 25. Volume transport of the ACC through the upper $2500 \mathrm{~m}$ of Drake Passage from across-passage differences of bottom pressure at 500m depth for January 1977 to February 1980 and for March 1981 to March 1982. The light curve shows 10 -day low-pass filtered transport, which is smoothed with a 90-day low pass filter (heavy curve) to illustrate the seasonal variablity. The inset shows yearlong segments of the 90-day low-passed series (WHITWORTH and PEIERSON, 1985).

side of the passage, has important components arising from the lunar fortnightly and monthly tides and baroclinic activity at the northern side of the passage, processes that are independant of wind. Although the time series of dynamic height at the two sides of the passage (which provided information on the baroclinic variability) were only a year long apiece, it was thought that most of the variability over seasonal time scales is barotropic. At the northern side of the passage the seasonal signal is largely annual, but not phase-locked, whereas at the southern side it has both annual and semi-annual components.

A nonlinear analytical model was presented by CLARXE (1982) which also shows that the seasonal transport fluctuations are barotropic, and that in the mean the Sverdrup balance does not hold for the ACC. This latter point seems to be the consensus of opinion (though STOMmel (1957) has argued that the ACC does not really occupy a zonal channel in which there are no Sverdrup solutions, but that there are partial meridional boundaries which could lead to much of the ACC's flow being Sverdrup-like). Many models have been formulated in which the ACC is driven by the eastward winds (see NowLIN and KLINCK, 1986), and a recent example is the work by JoHNSON and BRYDEN (1989) where the mean zonal momentum imparted by wind was seen as being transported downward by eddy form drag to be removed at great depth by bottom pressure drag.

Over seasonal time scales, the eastward wind stress in the Southern Ocean varies with a strongly semi-annual character, whereas bottom pressure at both sides of Drake Passage have important annual components. Curl of wind stress, on the other hand, changes from being mainly 
semi-annual at the higher latitudes to mainly annual north of about $45^{\circ} \mathrm{S}$. PETERSON (1988a) supposed that these differences in the seasonal variability of curl could conceivably lead to redistributions of mass through a Sverdrup-like response and therefore to changes in the slope of the sea surface across the ACC. The multi-year bottom pressure series at Drake Passage were then compared with zonally-averaged values of wind stress curl north and south of the $\mathrm{ACC}$, with the results showing that the annual cycle in the strengths of the subtropical highs is consistent with the annual signals in bottom pressure at both sides of the passage, whereas effects from the strong semi-annual variability of the subpolar lows are restricted to the southern side of the ACC. Fig.26 shows 3year long comparisons between the zonally-averaged curl of wind stress in a band along the northern side of the ACC $\left(40^{\circ}-46^{\circ} \mathrm{S}\right)$ and bottom pressure (inverted) at the northern side of the passage, and between curl along the southern side of the $\mathrm{ACC}\left(60^{\circ}-66^{\circ} \mathrm{S}\right)$ and bottom pressure at the southern side of the passage. The qualitative agreement is fairly good, except for a phase problem at the northern side during 1978. It was noted that if the ACC were closed along one side and subjected to the changes in curl along the other, the pure Sverdrup transport zonally-integrated along the current would be 2-3 orders of magnitude larger than needed to account for the observed changes in bottom pressure, indicating that the ACC's Sverdrup-like response is very small.

Also, a tacit assumption made in this type of analysis is that the seasonal fluctuations of ACC transport are zonally coherent, which is a very poorly understood problem. The only information about this comes from two studies using satellite al timeter data: Fuand CHELTON (1984) used three months of Seasat data to infer a general increase in the eastward surface velocity between $40^{\circ}$ and $65^{\circ} \mathrm{S}$, and CHELTON, SCHLAX, WITTER and RiCHMAN (1990) used empirical orthogonal functions on 26 months of Geosat data to find only a very weak zonal coherency in the lowest modes (primarily the annual and semi-annual cycles). But the latter study did not extend poleward of $60^{\circ} \mathrm{S}$, thus leaving the question of net flux from one basin to another unresolved. Additional in situ and satellite data are obviously needed.

Quasi-synoptic estimates of volume transport of the ACC in other regions of the South Atlantic have been few in number and are influenced by other flow regimes bordering the current. Between South Africa and Antarctica, JACOBS and GEORGI (1977) obtained a net eastward transport of 129Sv relative to the deepest observations, whereas Georgi and ToOLE (1982) otained 140Sv for the ACC (also relative to the deepest observations). WHTwORTH and NowLIN (1987) used a section extending from Cape Town to the Greenwich Meridian at about $40^{\circ} \mathrm{S}$ and then southward to the Antarctic continent to estimate the net eastward transport as $142 \mathrm{~Sv}$ relative to the bottom. Results from their computations are shown in Fig.27. The highest surface speeds, 26 and $23 \mathrm{~cm} \mathrm{~s}^{-1}$, are found at the SAF and PF, respectively, as are the greatest volume transports between station pairs. The STF, crossed at the north in the upper panel of Fig. 27 , has surface speeds of $13 \mathrm{~cm} \mathrm{~s}^{-1}$ and virtually no zonal flow beneath $2000 \mathrm{~m}$ depth (refer to section 3.5 for discussions of the STF). The other major front in this section is the ACC-Weddell Gyre Boundary, which has a surface speed of $12 \mathrm{~cm}$ $\mathrm{s}^{-1}$ just south of the mid-ocean ridge near $55^{\circ} \mathrm{S}$.

Finally, non-synoptic data have been used to compute the baroclinic transport function relative to $3000 \mathrm{~m}$ for the ACC as a whole. Inspection of Fig. $163 \mathrm{in}$ SvERDRUP, JoHNSON and FLEMING (1942) shows a net eastward flow south of Africa of about $90 \mathrm{~Sv}$, whereas LUTJEHARMS (1982) obtained a value of approximately $300 \mathrm{~Sv}$, one that does not include the westward flow of the the Agulhas Current (estimated by JACOBS and GeORGI, 1977 as being $136 \mathrm{~Sv}$ ) nor does it include any westward flow near the Antarctic continent. The disparity among these few estimates are large and point to a clear need for additional measurements in the region. 

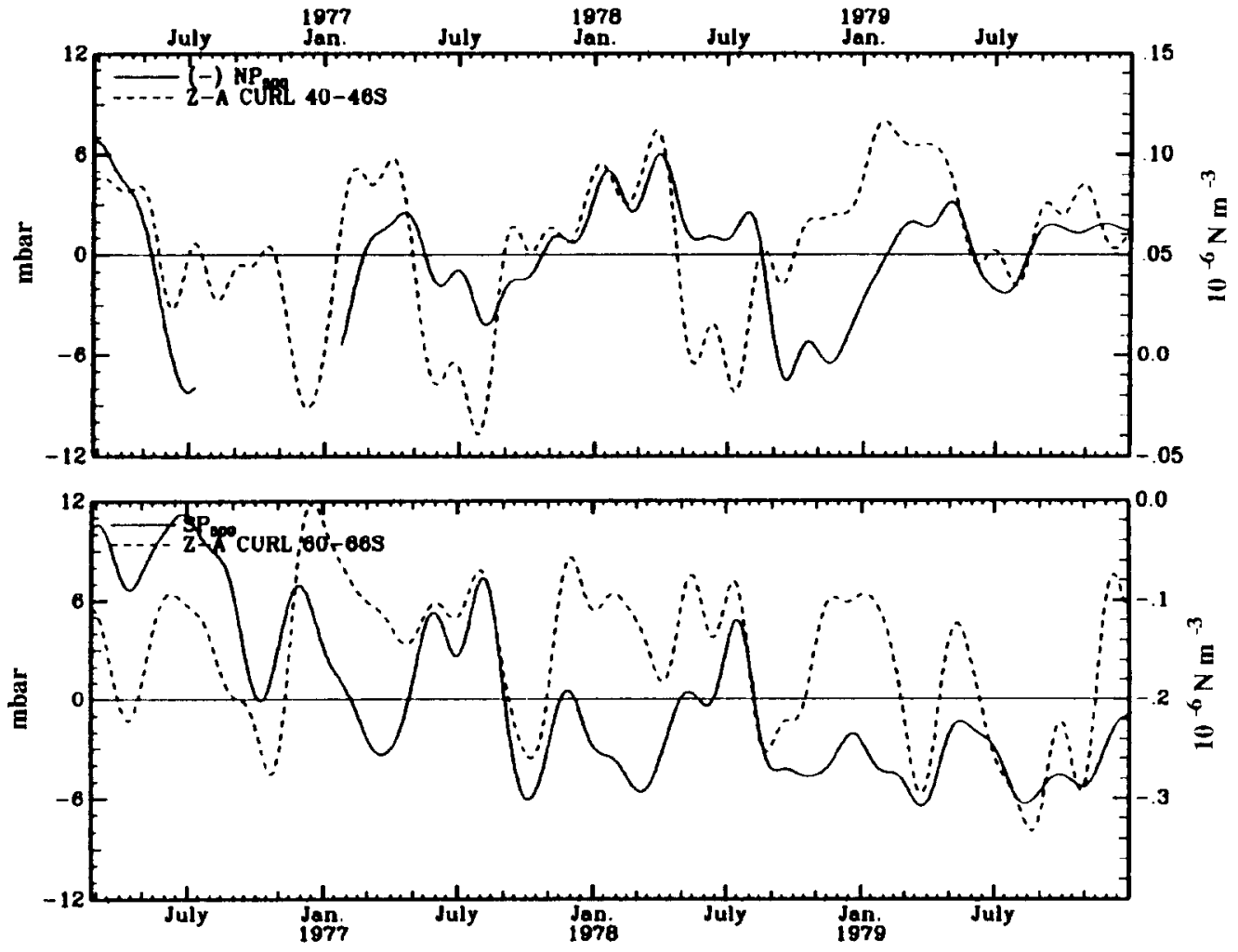

FIG. 26. (Top) Time series of zonally-averaged curl of wind stress (dashed curve) in the latitude band $40^{\circ}-46^{\circ} \mathrm{S}$, together with bottom pressure at $500 \mathrm{~m}$ depth (solid curve, inverted, mean removed) from the northem Drake Passage. (Bottom) Time series of zonally averaged curl of wind stress (dashed curve) in the latitude band $60^{\circ}-66^{\circ} \mathrm{S}$, together with bottom pressure at $500 \mathrm{~m}$ depth (solid curve, mean removed) from the southem Drake Passage. All series are smoothed with a 60-day low pass filter (Peterson, 1988a). 

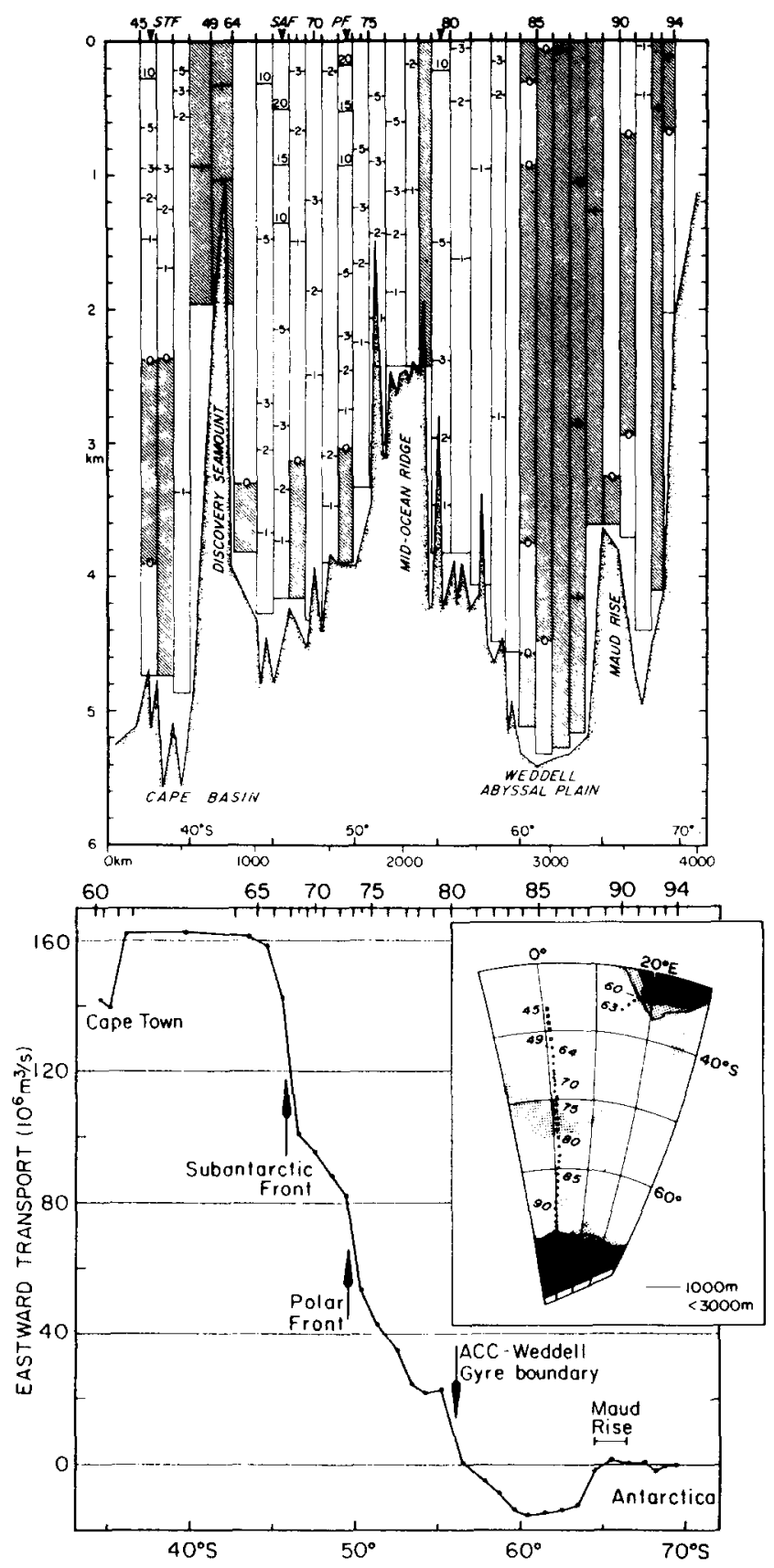

Fig. 27. (Top) Geostrophic speed ( $\mathrm{cm} \mathrm{s}^{-1}$, westward is shaded) and (bottom) integrated geostrophic transport $\left(10^{6} \mathrm{~m}^{3} \mathrm{~s}^{-1}\right)$, both relative to the deepest common sample depths for station pairs occupied by R/V Knorr during October 1983 (stations 45-49) and January to February 1984 (stations 60-94) (adapted from WHITwORTH and NowLIN, 1987). Note that the northern ends of these two panels do not follow the same lines (see inset). 


\section{MERIDIONAL HEAT TRANSPORT}

Because the South Atlantic is the major conduit for water mass exchanges between the globally-important sources for deep water masses in the North Atlantic and the rest of the World Ocean, it has a unique pattern of heat transport which is directed toward the equator at mid- and low-latitudes, contrary to an intuitive point of view where heat transport would be expected to be directed in a symmetric fashion away from the equator. Although we do not discuss the deep circulation here in any detail, it nonetheless seems appropriate to give a brief summary of estimates of meridional heat transport in the South Atlantic.

According to RoEMMICH (1983), approximately $10 \mathrm{~Sv}$ of warm upper-ocean water is transported northward across the equator from the South Atlantic, which is compensated by a comparable southward transport of North Atlantic Deep Water. SvERDRUP, JOHNSON and FLEMING (1942,pg. 629) discussed this balance, which GoRDON (1986) identified as being an important part of a global-scale thermohaline circulation cell. With an inverse model, however, RINToul (1990) calculated that an export of $17 \mathrm{~Sv}$ of deep water from the North Atlantic is balanced by an equatorward return flow equally split between the surface layers and the intermediate and bottom water. The South Atlantic can thus be seen as the link between the North Atlantic and the other oceans in the global thermohaline circulation.

Although it is generally accepted that the South Atlantic has a northward heat flux, the exact magnitudes are difficult to compute owing to large uncertainties in the computational methods and to the unknown sizes of interannual and seasonal variability south of about $20^{\circ} \mathrm{S}$. With respect to computational methods, there are two classes that utilize observed quantities, the direct and indirect methods. For the direct method, absolute velocities must be known, both the Ekman and geostrophic components. Monthly mean values of meridional Ekman heat fluxes were computed by Levrrus (1987) for the individual ocean basins. Poleward of $30^{\circ} \mathrm{S}$ in the South Atlantic, the zonally-averaged meridional fluxes are less than $0.5 \mathrm{PW}$, which are small when compared with the Ekman heat fluxes north of $30^{\circ} \mathrm{S}$, which are directed toward the south. A seasonal signal is evident in the latitude band of $0^{\circ}-15^{\circ} \mathrm{S}$, with the largest changes occurring at $4.5^{\circ} \mathrm{S}$; during May to October there is a maximum southward Ekman heat flux of 2.5PW, whereas during January to March it reduces to about $1.5 \mathrm{PW}$. The latitude band of $15^{\circ}-30^{\circ} \mathrm{S}$ is marked by a relatively constant Ekman heat flux throughout the year.

For indirect computations, there are two fundamentally different approaches. The classical method has been to consider air-sea interactions and temporal changes of heat storage in the water column. The energy fluxes across the sea surface are summarized in section 2 of this paper. The annual cycle of heat storage for the individual ocean basins was computed by LEvrrus (1984) on the basis of climatological monthly-mean temperature fields. One of the results is that at midlatitudes the annual cycle of oceanic heat storage lags that of the incoming solar radiation by about three months. In the mid-latitude South Atlantic, maximum heat storage occurs in March and minimum storage in September. For a $5^{\circ}$ wide latitude belt centered at $27.5^{\circ} \mathrm{S}$, the heat stored in the upper $275 \mathrm{~m}$ of the South Atlantic is $72.2 \times 10^{20} \mathrm{~J}$ in excess of the annual mean during February to April, whereas there is a deficit of $70.9 \times 10^{20} \mathrm{~J}$ during August to October. Using a larger data set, Hsiung, NEwELl and HoughtBy (1989) also computed monthly means of heat storage in the Atlantic Ocean north of $20^{\circ} \mathrm{S}$, finding good agreement with the results of Levrrus (1984).

The other indirect method uses incoming and outgoing atmospheric radiation combined with atmospheric heat transport to derive the oceanic component as a residual. This method has revealed that meridional heat fluxes in both the ocean and atmosphere (northern hemisphere) lie in the range of $0.1-1 \mathrm{PW}$, with the ocean contributing more in the tropics and the atmosphere more 

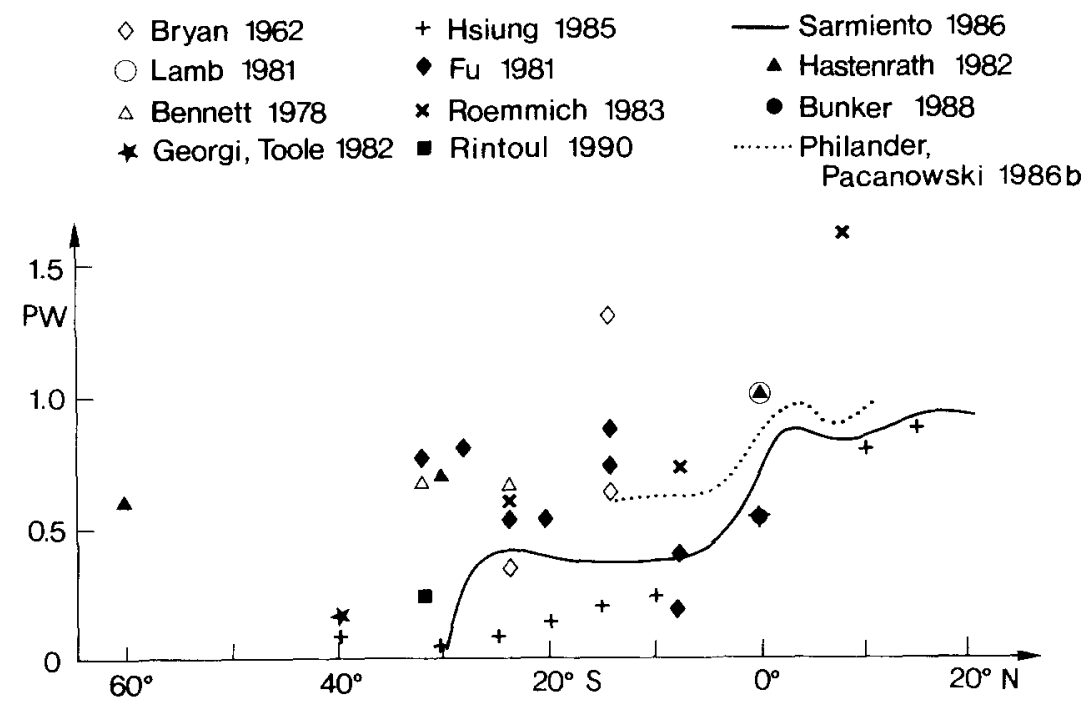

FIG. 28. Total northward heat transport (PW) of the South and tropical Atlantic Ocean. Symbols correspond to the indicated sources.

TABLE 4. Estimates of northward heat transport (PW) in the South Atlantic Ocean derived from (s) indirect computations using surface estimates, (h) direct computations using hydrographic data to solve for velocities, and (m) from numerical circulation models. The values attributed to SARMIENTO (1986) and PHIILANDER and PACANOWSKI (1986b) are adopted from figures shown in their papers. Those for Fu (1981) are mean values of results given for each section

\begin{tabular}{|c|c|c|c|c|c|c|c|c|c|c|}
\hline \multirow[t]{2}{*}{ Author } & \multirow[t]{2}{*}{ Method } & \multicolumn{9}{|c|}{ Latitude $\left({ }^{\circ} \mathrm{S}\right)$} \\
\hline & & 0 & 8 & $15-16$ & $20-21$ & 24 & 28 & 30 & 32 & 60 \\
\hline Hsiung (1985) & $\mathrm{s}$ & 0.54 & & & 0.15 & & & 0.04 & & \\
\hline HASTENRATH (1982) & $\mathbf{s}$ & 0.98 & & & & & & 0.69 & & 0.60 \\
\hline BUNKER $(1988)$ & $\mathbf{s}$ & 0.54 & & & & & & & & \\
\hline LAMB (1981) & $s$ & 1.02 & & & & & & & & \\
\hline BENNETT (1978) & h & & & & & 0.65 & & & 0.68 & \\
\hline BRYAN (1962) (Meteor) & $\mathbf{h}$ & & & 0.63 & & & & & & \\
\hline BRYAN (1962) (IGY) & h & & & 1.30 & & 0.33 & & & & \\
\hline Fu (1981) (Meteor) & $\mathbf{h}$ & & 0.41 & 0.86 & 0.54 & & 0.83 & & & \\
\hline Fu $(1981)(I G Y)$ & h & & 0.18 & 0.73 & & 0.54 & & & 0.77 & \\
\hline ROEMMCH (1983) & h & & 0.74 & & & 0.61 & & & & \\
\hline Rentoul (1990) & $\mathbf{h}$ & & & & & & & & 0.15 & \\
\hline SARMIENTO (1986) & $\mathbf{m}$ & 0.70 & 0.38 & 0.37 & 0.40 & 0.44 & 0.27 & & & \\
\hline PHIL_ANDER and & & & & & & & & & & \\
\hline PACANOWSKI (1986b) & $\mathbf{m}$ & 0.86 & 0.64 & & & & & & & \\
\hline
\end{tabular}


in the higher latitudes (OORT and VONDER HAAR, 1976). Lastly, oceanic circulation models are also used to estimate heat fluxes.

The various estimates of northward heat transport in the South Atlantic Ocean are summarized in Table 4 and in Fig.28. As can be seen, all the estimates are positive (northward), but with large differences in magnitude among them. The disparities likely result from a combination of large seasonal variations (HsIUng, NEwELL and HoughtBy, 1989) and computational uncertainties. For example, by using different widths for the western boundary current, BENNETT (1978) obtained northward heat transports across $32^{\circ} \mathrm{S}$ that varied from 0.16 to $0.68 \mathrm{PW}$. Also, Table 4 shows that even when the same Meteor and IGY sections are used, investigators using different methods obtain widely varying estimates.

Using a general circulation model of the tropical AtlantIC OCEAN, PhilaNDER AND Pacanowski (1986b) found little seasonal variability of heat transport across $5^{\circ} \mathrm{S}$. However, the northward heat flux across $12^{\circ} \mathrm{S}$ was seen to vary from $0.4 \mathrm{PW}$ in August to $0.8 \mathrm{PW}$ in February. They also computed heat flux across the sea surface in their model finding clear seasonality at latitudes higher than about $10^{\circ}$. At $12^{\circ} \mathrm{S}$, there was a $25 \mathrm{~W} \mathrm{m-2}$ gain by the ocean in February (austral summer) and an equal loss in August. Hsiung, NEwEL And Houghtby (1989) investigated seasonal variations in heat transport between $50^{\circ} \mathrm{N}$ and $20^{\circ} \mathrm{S}$ with oceanic observations and indirect computations. Fig. 29 shows their results for the latitude band of $20^{\circ} \mathrm{N}-20^{\circ} \mathrm{S}$. With the exception of southward heat transport in the tropical South Atlantic for about three months in the austral summer, all of their other monthly values are northward. But contrary to the model results of PhilaNDER AND Pacanowski (1986b), Hsiung, NEwELl And Houghtby (1989) found large seasonal variations of heat transport across $5^{\circ} \mathrm{S}$, ranging from a southward transport of 1.7PW in January to a northward value of 1.6PW in March. Figure 29 also shows direct estimates from a number of sources, which agree rather well on the whole with the indirect computATions of Hsiung, NEwEL And Houghtby (1989). Therefore, much of the scatter in Fig.28 is probably a result of seasonal variablity.

\section{OUTLOOK}

In this paper we have attempted to provide a moderately detailed review of the upper-level circulation in the South Atlantic Ocean. Although portions of the system of currents comprising this circulation are fairly well understood, such as the Agulhas Current Retroflection, parts of the Brazil Current, and the Antarctic Circumpolar Current within Drake Passage, there are still large regions of the South Atlantic that have yet to be measured in detail, either spatially or through time. We have only a vague idea of how bottom topography influences the course of the Benguela Current, only very recent indications that the cyclonic geostrophic gyre in the Angola Basin is a permanent feature, no solid understanding of how the equatorial currents feed into that gyre nor of how water is exchanged between the individual current bands of the equatorial system. The seasonal variability of the equatorial current system is becoming better understood, but how this, and the atmospheric seasonality translates into the Brazil Current is not known at all. How do the Agulhas eddies moving across the South Atlantic affect the Brazil Current? We have very little information concerning the flow field in the interior regions of the subtropical gyre, and only recently has there been a description of the current band that closes the gyre in the south. Does the South Atlantic Current always turn completely north into the Benguela Current, or does a significant amount of subtropical water ever flow directly from the Atlantic into the Indian Ocean? How much thermocline water is lost to the Antarctic Circumpolar Current through the southward shedding of Brazil Current eddies into the Subantarctic Zone? 


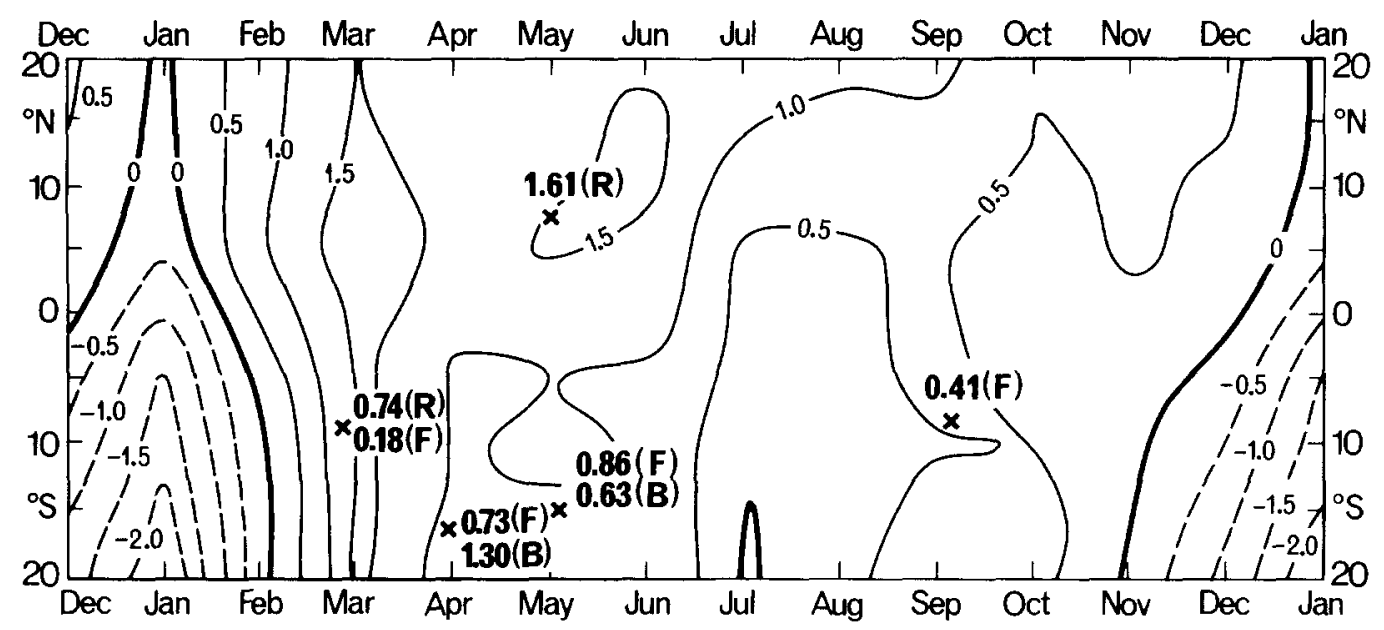

FIG. 29. Monthly zonal averages of northward heat transport (PW) for the Atlantic Ocean between $20^{\circ} \mathrm{N}$ and $20^{\circ} \mathrm{S}$ (adapted from HsIUNG, NEWEL and HougHTBY, 1989). Also shown are estimates from the direct method of computation denoted with letters corresponding to their source: B - BRYAN (1962), R - ROEMMICH (1983), F - Fu (1981).

There are equally important uncertainties with the circumpolar current in much of the South Atlantic. The northward flow of the Falkland Current appears to be bottom-reaching, and when transport estimates bearing this consideration are made they come up to be much larger than had usually been thought. How much of this water continues north without returning to the circumpolar current, and how would this affect the meridional heat and salt fluxes in the South Atlantic and the overall balance in the global thermohaline circulation? Is there any seasonality in the strength of the Falkland Current, as might be anticipated by the seasonal transport fluctuations of the Antarctic Circumpolar Current? How would this relate to the apparent seasonality in the separation of the Brazil Current? What happens to the water between the major fronts of the ACC when the fronts come together? There must certainly be important meridional exchanges in such occurrences.

These are only a few of the questions concerning the upper-level circulation in the South Atlantic that might be raised, and a host of others exist for the deep circulation as well. It is clear that much work remains to be done, and with improvements in our knowledge of circulation in the South Atlantic, there will come improved input to coupled atmosphere-ocean models, which would lead to better predictions of future climatic states. Field experiments planned for the South Atlantic during the forthcoming World Ocean Circulation Experiment and other activities will no doubt provide the basis for filling large gaps in our understanding of this extraordinary ocean.

\section{ACKNOWLEDGEMENTS}

This work has been supported by the Deutsche Forschungsgemeinschaft grant Si 111/34-1 (RGP) and by the Bundesminister für Forschung und Technologie grant 07KF2128-12a (LS), both in Bonn, Federal Republic of Germany. We would like to thank Sophie Wacongne and Robert Molinari for their helpful comments. 


\section{REFERENCES}

ADAMEC, D. and J.J. O'Brien (1978) The seasonal upwelling in the Gulf of Guinea due to remote forcing. Journal of Physical Oceanography, 18, 1050-1060.

ARNAULT, S.(1987) Tropical Atlantic geostrophic currents and ship drifts. Journal of Geophysical Research, 92,50765088.

ARTHUR, R.S. (1960) A review of the calculation of ocean currents at the equator. Deep-Sea Research, 6, 287-297.

BANG, N.D. (1970) Dynamic interpretations of a detailed surface temperature chart of the Agulhas Current retroflexion and fragmentation area. South African Geographical Journal, 52, 67-76.

BANG, N.D. (1973) Characteristics of an intense ocean frontal system in the upwell regime west of Cape Town. Tellus, 25, 256-265.

BANG, N.D. and W.R.H. ANDREWS (1974) Direct current measurements of a shelf-edge frontal jet in the Southern Benguela system. Journal of Marine Research, 32, 405417.

BarLow, E.W. (1931) Currents in the western portion of the Indian Ocean. Parts I, II, III. Marine Observer, 8, 130$132,193-194,254-259$.

BENNETT, A.F. (1978) Poleward heat fluxes in the southem hemisphere oceans. Journal of Physical Oceanography, 8, 785-798.

BENNETT, S.L. (1988) Where Three Oceans Meet: the Agulhas Retroflection Region. Ph.D. dissertation, WHOI-8851, Woods Hole Oceanographic Institution/Massachusetts Institute of Technology Joint Program in Oceanography, Woods Hole, Massachusetts, 367 pp.

BERSCH, M. and G.A. BECKER (1986) The surface expression of the western Weddell-Scotia Confluence. Meeresforschung, 31, 58-69.

BJERKNes, J. (1969) Atmospheric teleconnection from the equatorial Pacific. Monthly Weather Review, 97, 163-172.

BLECK, R. and D.B. BoudRA (1981) Initial testing of a numerical ocean circulation model using a hybrid (quasiisopycnic) vertical coordinate. Journal of Physical Oceanography, 11, 755-770.

BÖHNECKE, G. (1936) Temperatur, Salzgehalt und Dichte an der Oberfläche des Atlantischen Ozeans. Wissenschaftliche Ergebnisse der Deutschen Atlantischen Expedition Forschungs- und Vermessungsschiff Meteor 1925$1927,5,1-249$.

BosLeY, K.T. (1990) A simple model for the cyclonic gyre of the South Atlantic. Abstract in: Eos, 71(17), 544.

BotNIKov, V.N. (1963) Geographical position of the Antarctic convergence zone in the Pacific Ocean. Soviet Antarctic Information Bulletin, 4, 324-327.

BoudRA, D.B. and E.P. Chassignet (1988) Dynamics of Agulhas Retroflection and ring formation in a numerical model. Part I: The vorticity balance. Journal of Physical Oceanography, 18, 280-303.

BOUDRA, D.B. and W.P.M. DE RUdTER (1986) The wind-driven circulation of the South Atlantic-Indian Ocean-II. Experiments using a multi-layer numerical model. Deep-Sea Research, 33, 447-482.

Brown, O.B., R.H. Evans, D.B. Otson and G. PoDESTA (1985) A satellite infrared survey of the Brazil/Falklands Confluence. Abstract in: Eos, 66(18), 291.

BryAN, K. (1962) Measurements of meridional heat transport by ocean currents. Journal of Geophysical Research, 67, 3403-3414.

BRYDEN, H.L. and E.C. BRADY (1985) Diagnostic model of the three-dimensional circulation in the upper equatorial Pacific Ocean. Journal of Physical Oceanography, 15, 1255-1273.

Bryden, H.L. and R.D. Pllssbury (1977) Variability of deep flow in Drake Passage from yearlong current measurements. Journal of Physical Oceanography, 7, 803-810.

Bunker, A.F. (1988) Surface energy fluxes of the South Atlantic Ocean. Monthly Weather Review, 116, 809-823.

BuRLING, R.W. (1961) Hydrology of circumpolar waters south of New Zealand. Bulletin 143, New Zealand Department of Scientific and Industrial Research, 66pp.

CANE, M.A. (1983) Oceanographic events during El Niño. Science, 222, 1189-1195.

CANE,M.A. andE.S. SARACHIK (1983) Equatorial oceanography. Reviews of Geophysics and Space Physics, 21,11371148.

CAVIEDEs, C.N. (1973) Sêcas and El Niño: Two simultaneous climatical hazards in South America. Proceedings of the Association of American Geographers, 5, $44-49$.

Chapman, P. and L.V. Shannon (1985) The Benguela ecosystem. 2. Chemistry and related processes. In: Oceanography and Marine Biology, An Annual Review, 23, M. BARNEs, editor, Aberdeen University Press, 183251.

Chassignet, E.P. and D.B. Boudra (1988) Dynamics of Agulhas Retroflection and ring formation in a numerical 
model. Part II. Energetics and ring formation. Journal of Physical Oceanography, 18, 304-319.

ChELTon, D.B. (1982) Statistical reliability of the seasonal cycle: Comments on "Bottom pressure measurements across the Antarctic Circumpolar Current and their relation to wind." Deep-Sea Research, 29, 1381-1388.

Chelton, D.B., M.G. Schlax, D.L. WITTER and J.G. Richiman (1990) Geosat Altimeter observations of the surface circulation of the Southern Ocean. Journal of Geophysical Research (in press).

CHENEY, R.E., J.G. MARSH and B.D. BECKLEY (1983) Global mesoscale variability from collinear tracks of SEASAT altimeter data. Journal of Geophysical Research, 88, 4343-4354.

Clarke, A.J. (1982) The dynamics of large-scale, wind-driven variations in the Antarctic Circumpolar Current. Journal of Physical Oceanography, 12, 1092-1105.

CLIFFord, M.A. (1983) A descriptive study of the zonation of the Antarctic Circumpolar Current and its relation to wind stress and ice cover. M.S. thesis, Texas A\&M University, College Station, 93pp.

CLowes, A.J. (1933) Influence of the Pacific on the circulation in the South-West Atlantic Ocean. Nature, London, 131, 189-191.

CLowes, A.J. (1950) An introduction to the hydrology of South African waters. Investigational Report 12, Fisheries and Marine Biological Survey Division, South Africa, 28 pp., 20 charts.

COCHRANE, J.D., F.J. KHLIY, JR. and C.R. OLING (1979) Subthermocline countercurrents in the western equatorial Atlantic Ocean. Journal of Physical Oceanography, 9, 724-738.

CoveY,D.L. andS. HASTENRATH (1978) The Pacific ElNiñophenomenon and the Atlantic circulation. Monthly Weather Review, 106, 1280-1287.

DARBYSHIRE, J. (1972) The effect of bottom topography on the Agulhas Current. Pure and Applied Geophysics, 101, 208-220.

DARBYSHIRE, M. (1963) Computed surface currents off the Cape of Good Hope. Deep-Sea Research, 10, 623-632.

DEACON, G.E.R. (1933) A general account of the hydrology of the South Atlantic Ocean. Discovery Reports, 7, 171238.

DeAcon, G.E.R. (1937) The hydrology of the Southem Ocean. Discovery Reports, 15, 3-122, 44 plates.

DeAcon, G.E.R. and T.D. Foster (1977) The boundary between the Weddell Sea and Drake Passage currents. DeepSea Research, 24, 505-510.

Deacon, G.E.R. and J.A. Moorey (1975) The boundary region between currents from the Weddell Sea and Drake Passage. Deep-Sea Research, 22, 265-268.

Derant, A. (1928) Die systematische Erforschung des Weltmeeres. In: Zeitschrift der Gesellschaft für Erdkunde zu Berlin, Sonderband zur Hundertjahrfeier der Gesellschaft, Berlin, 551 pp., 41 plates.

DEFANT, A. (1936) Schichtung und Zirkulation des Atlantischen Ozeans, Die Troposphäre. Wissenschaftliche Ergebnisse der Deutschen Atlantischen Expedition Forschungs- und Vermessungsschiff Meteor 1925-1927, 6(1), 289-411.

Depant, A. (1961) Physical Oceanography, Volume 1, Pergamon Press, 729 pp.

DE RUUTER, W.P.M. and D.B. BOUdRA (1985) The wind-driven circulation in the South Atlantic-Indian Ocean. I. Numerical experiments in a one-layer model. Deep-Sea Research, 32, 557-574.

DiETRICH, G. (1935) Aufbau und Dynamik des südlichen Agulhasstromgebietes. Veröffentlichungen des Instituts für Meereskunde, Universităt Berlin, A(27), 79 pp.

DIETRICH, G. (1936) Aufbau und Bewegung von Golfstrom und Agulhasstrom, eine vergleichende Betrachtung. Naturwissenschaften, 24, 225-230.

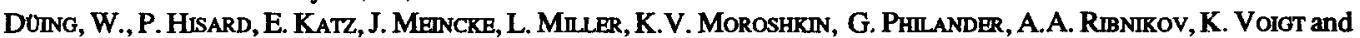
R. WeisBerg (1975) Meanders and long waves in the equatorial Atlantic. Nature, London, 257, 280-284.

Duncan, C.P. (1968) An eddy in the Subtropical Convergence southwest of South Africa. Journal of Geophysical Research, 73, 531-534.

Duncan, C.P. (1970) The Agulhas Current. Ph.D. thesis, University of Hawaii, 76 pp.

EMERY, W.J. (1977) Antarctic Polar Frontal Zone from Australia to the Drake Passage. Journal of Physical Oceanography, 7, 811-822.

ERIKSEN, C.C. and E.J. KATZ (1987) Equatorial dynamics. Reviews of Geophysics, 25, 217-226.

EsKIN, L.I. (1959) Contribution to the study of the water and thermal balance of Drake Passage (in Russian). Information Byulletin Sovetskaia Antarkticheskaia ekspedifsiia, 12, 29-32 (English translation in: Soviet Antarctic Expedition Information Bulletin, 2, 52-55, 1964).

Evans, D.L. and S.S. SIGNORIN (1985) Vertical structure of the Brazil Current. Nature, London, 315, 48-50.

EVANS, D.L., S.R. SIGNORINI and L.B. MIRANDA (1983) A note on the transport of the Brazil Current. Journal of Physical Oceanography, 13, 1732-1738. 
FAHRBACH, E., J. MEINCKE and A. Sy (1986) Observations of the horizontal separation of the salinity core and the current core in the Atlantic Equatorial Undercurrent. Journal of Marine Research, 44, 763-779.

FANDRY, C. and R.D. PulsBURY (1979) On the estimation of absolute geostrophic volume transport applied to the Antarctic Circumpolar Current. Journal of Physical Oceanography, 9, 449-455.

FofoNoFr, N.P. and R.B. MONTGOMERY (1955) The Equatorial Undercurrent in light of the vorticity equation. Tellus, 7, 518-521.

Foster, L.A. (1972) Current measurements in the Drake Passage. M.S. thesis, Dalhousie University, Halifax, Nova Scotia, $61 \mathrm{pp}$.

Fu, L.-L. (1981) The general circulation and meridional heat transport of the subtropical South Atlantic determined by inverse methods. Journal of Physical Oceanography, 11, 1171-1193.

Fu, L.-L. and D.B. Chel.ton (1984) Temporal variability of the Antarctic Circumpolar Current observed from satellite altimetry. Science, 226, 343-346.

FugILISTER F.C. (1960) Atlantic Ocean atlas of temperature and salinity profiles and data from the Intemational Geophysical Year of 1957-1958. Atlas Series, Volume 1, Woods Hole Oceanographic Institution, Woods Hole, Massachussetts, 209 pp.

GARFIELD, N. (1988) Surface characteristics of the Brazil Current. Abstract in: Eos, 69(44), 1237.

GARZOLI, S.L. and A. BIANCHI (1987) Time-space variability of the local dynamics of the Malvinas-Brazil Confluence as revealed by inverted echo sounders. Journal of Geophysical Research, 92, 1914-1922.

Garzoli, S.L. and Z. Garraffo (1989) Transport, frontal motions and eddies at the Brazil-Malvinas Confluence. Deep-Sea Research, 36, 681-703.

GeORgi, D.T. and J.M. Toole (1982) The Antarctic Circumpolar Current and the oceanic heat and freshwater budgets. Journal of Marine Research, 40 (supplement), 183-197.

GodoI, S.S. DE (1982) Estudo das variaçoes sazonais da Frenta Oceânica Subtropical entre a Corrente do Brasil e a Corrente das Malvinas, utilizando dados oceanográficos e do satélite SMS-2. Dissertaçao de Mestrado em Sensoriamento Remoto, Publicaçao no.INPE-2780-TDL/137, Instituto de Pesquisas Espaciais, Sao José, Brasil, 328 pp.

GoRDon, A.L. (1966) Potential temperature, oxygen and circulation of bottom water in the Southem Ocean. DeepSea Research, 13, 1125-1138.

Gordon, A.L. (1967) Geostrophic transport through the Drake Passage. Science, 156, 1732-1734.

Gordon, A.L. (1981) South Atlantic thermocline ventilation. Deep-Sea Research, 28, 1239-1264.

Gordon, A.L. (1985) Indian-Atlantic transfer of thermocline water at the Agulhas Retroflection. Science, 227, 10301033.

GoRDon, A.L. (1986) Interocean exchange of thermocline water. Journal of Geophysical Research, 91, 5037-5046.

Gordon, A.L. (1989) Brazil-Malvinas Confluence - 1984. Deep-Sea Research, 36, 359-384.

Gordon, A.L. and K.T. Bosley (1990) Cyclonic gyre in the tropical South Atlantic. Deep-Sea Research (in press).

Gordon, A.L., D.T. GeORGI and H.W. TAYLOR (1977) Antarctic Polar Front zone in the western Scotia Sea - summer 1975. Journal of Physical Oceanography, 7, 309-328.

Gordon, A.L. and C.L. GreEnGrove (1986) Geostrophic circulation of the Brazil-Falkland confluence. Deep-Sea Research, 33, 573-585.

Gordon, A.L. and W.F. HAXBY (1990) Agulhas eddies invade the South Atlantic: Evidence from Geosat altimeter and shipboard conductivity-temperature-depth survey. Journal of Geophysical Research, 95, 3117-3125.

Gordon, A.L., J.R.E. LUTJEHARMS and M.L. GrUNDLINGH (1987) Stratification and circulation at the Agulhas Retroflection. Deep-Sea Research, 34, 565-599.

GoRDon, A.L. and W.D. Nowlin, JR. (1978) The basin waters of the Bransfield Strait. Journal of Physical Oceanography, 8, 258-264.

Gordon, A.L. and A.R. Piola (1983) Atlantic Ocean upper layer salinity budget. Journal of Physical Oceanography, 13, 1293-1300.

GoRdon, A.L., H.W. TAYLOR and D.T. GBORGI (1974) Antarctic oceanographic zonation. In : Proceedings of the SCOR/SCAR Polar Oceans Conference, 5-1L May 1974, McGill University, Montreal, 682 pp.

Greengrove, C.L. (1986) Thermohaline alteration of the South Atlantic pycnocline. Ph.D. dissertation, LamontDoherty Geological Observatory of Columbia University, Palisades, New York, 211 pp.

GRIFFTTHS, C.L. (1981) Upwelling processes in the southem Benguela region. South African Journal of Science, 77 , 99-100.

GRUNDLINGH, M.L. (1977) Drift observation from Nimbus VI satellite-tracked buoys in the southwestern Indian Ocean. Deep-Sea Research, 24,903-913. 
GrundLnom, M.L. (1978) Drift of a satellite-tracked buoy in the southem Agulhas Current and Agulhas Return Current. Deep-Sea Research, 25, 1209-1224.

GrOndLINoH, M.L. (1980) On the volume transport of the Agulhas Current. Deep-Sea Research, 27, 557-563.

GRONDLINGH, M.L. (1983) On the course of the Agulhas Current. South African Geographical Journal, 65, 49-57.

HAN, Y.-J. and S.-W. LEE (1981) A new analysis of monthly mean wind stress over the global ocean. Report 26, Climate Research Institute, Oregon State University, Corvallis, 148 pp.

HARRIS, T.F.W. and N.D. BANg (1974) Topographic Rossby waves in the Agulhas Current. South African Journal of Science, 70, 212-214.

HARRIS, T.F.W., and D. van Foreest (1978) The Agulhas Current in March 1969. Deep-Sea Research, 25, 549-561.

HARRIs, T.F.W., R. LeGECKIS and D. VAN FoREEST (1978) Satellite infra-red images in the Agulhas Current system. Deep-Sea Research, 25, 543-548.

HART, T.J. and R.I. CurRIE (1960) The Benguela Current. Discovery Reports, 31, 123-298.

HASTENRATH, S. (1982) On meridional heat transport in the world ocean. Journal of Physical Oceanography, 12,922927.

HASTENRATH, S. and L. HelleR (1977) Dynamics of climatic hazards in northeast Brazil. Quarterly Journal of the Royal Meteorological Society, 103, 77-92.

HASTENRATH, S. and P.J. LAMB (1977) Climatic Atlas of the Tropical Atlantic and Eastern Pacific Ocean. University of Wisconsin Press, Madison, 15 pp., 97 charts.

HeAtH, R.A. (1981) Oceanic fronts around southem New Zealand. Deep-Sea Research, 28, 547-560.

HELLERMAN, S. and M. RoseNSTEIN (1983) Normal monthly wind stress over the World Ocean with error estimates. Journal of Physical Oceanography, 13, 1093-1104.

HIRST, A.C. and S. HASTENRATH (1983) Atmosphere-ocean mechanisms of climate anomalies in the Angola-tropical Atlantic sector. Journal of Physical Oceanography, 13, 1146-1157.

Hisard, P. (1980) Observation de réponses de type "El Niño" dans l'Atlantique tropical oriental Golfe de Guinée. Oceanologica Acta, 3, 69-78.

HöFL_. in the Atlantic Ocean. GATE Reports, 2, Part VI, 36 pp.

HÖFLICH, O. (1984) Climate of the South Atlantic Ocean. In: World Survey of Climatology, Volume 15, Climates of the Oceans, H. vAN LooN, editor, Elsevier, Amsterdam, 1-191.

HofmaNn, E.E. (1985) The large-scale horizontal structure of the Antarctic Circumpolar Current from FGGE drifters. Journal of Geophysical Research, 90, 7087-7097.

HoReL, J.D., V.E. KousKY and M.T. KaGANo (1986) Atmospheric conditions in the Atlantic sector during 1983 and 1984. Nature, London, 322, 248-251.

Hougrton, R.W. (1976) Circulation and hydrographic structure over the Ghana Continental Shelf during the 1974 upwelling. Journal of Physical Oceanography, 6, 910-924.

Houghton, R.W. (1989) Influence of local and remote forcing in the Gulf of Guinea. Journal of Geophysical Research, 94, 4816-4828.

Houghton, R.W. and C. CoLn (1986) Thermal structure along $4^{\circ} \mathrm{W}$ in the Gulf of Guinea during 1983-1984. Journal of Geophysical Research, 91, 11727-11739.

HsuUNo, J. (1985) Estimates of global oceanic heat meridional transport. Journal of Physical Oceanography, 15, 14051413.

HsIuNG, J., R.E. NEwELL and T. HoughtBy (1989) The annual cycle of oceanic heat storage and oceanic meridional heat transport. Quarterly Journal of the Royal Meteorological Society, 115, 1-28.

IKEDA, Y., L.B. MRANDA and N.J. Rock (1974) Observations on stages of upwelling in the region of Cabo Frio (Brazil) as conducted by continuous surface temperature and salinity measurements. Boletim do Instituto Oceanografico, Sao Paulo, 23, 33-46.

IKEDA, Y., G. SIEDLER and M. ZWIERZ (1989) On the variability of Southem Ocean front locations between southem Brazil and the Antarctic Peninsula. Journal of Geophysical Research, 94, 4757-4762.

JACOBS, S.S. and D.T. GEORGI (1977) Observations on the southwest Indian/Antarctic Ocean. In: A Voyage of Discovery, M. ANGEL, editor, Pergamon Press, 43-84.

Johnson, G.C. and H.L. Bryden (1989) On the size of the Antarctic Circumpolar Current. Deep-Sea Research, 36, 39-53.

JoHNSON, M.A. (1989) Southern Ocean surface characteristics from FGGE buoys. Journal of Physical Oceanography, 19, 696-705.

JoNEs, P.G.W. (1971) The southem Benguela Current region in February, 1966: Part I, Chemical observations with 
particular reference to upwelling. Deep-Sea Research, 18, 193-208.

KIRWAN, A.D. (1963) Circulation of Antarctic Intermediate Water deduced through isentropic analysis. TAMU reference 63-34F, Texas A\&M University, College Station, 34 pp., 35 plates.

KNOL,, M., W.ZENK and E. BAUER (1982) Some XBT-observations on the thermal structure of the Warmwassersphäre in equatorial and lower latitudes of the eastern Atlantic. Deutsche Hydrographische Zeitschrift, 35, 73-81.

KNOX, R.A. and D.L.T. ANDERSON (1985) Recent advances in the study of low-latitude ocean circulation. Progress in Oceanography, 14, 259-317.

KoRT, V.G. (1959) New data on the transport of Antarctic waters (in Russian). Information Byulletin Sovetskaia Antarkticheskaia ekspedifsiia, 9, 31-34 (English translation in: Soviet Antarctic Expedition Information Bulletin, 1, 358-361, 1964).

Krauss, W. (1986) The North Atlantic Current. Journal of Geophysical Research, 91, 5061-5074.

KRTMMMEL, O. (1882) Bemerkungen über die Meeresströmungen und Temperaturen in der Falklandsee.Aus dem Archiv der Deutschen Seewarte, V, Hamburg, Nr. 2, 25 pp.

LAMB, P.J. (1977) On the surface climatology of the tropical Atlantic. Archiv für Meteorologie, Geophysik und Bioklimatologie, Serie B., 25, 21-31.

LAMB, P.J. (1981) Estimate of annual variation of Atlantic Ocean heat transport. Nature, London, 290, 766-768.

LAMB, P.J., R.A. PEPPLER and S. HASTENRATH (1986) Interannual variability in the tropical Atlantic. Nature, London, 322, 238-240.

LEETMAA, A., J.P. MCCREARY, JR. and D.W. MOORE (1981) Equatorial currents: measurements and theory. In: Evolution of Physical Oceanography, B.A. WARREN and C. WUNSCH, editors, MTT Press, Cambridge, Massachussetts, 184-196.

LEGECKIs, R. and A.L. GoRDON (1982) Satellite observations of the Brazil and Falkland currents -1975 to 1976 and 1978. Deep-Sea Research, 29, 375-401.

LENZ, W. (1975) Untersuchungen zur inneren hydrographischen Struktur des südlichen und mittleren Atlantiks (0$2000 \mathrm{~m}$ Tiefe) mit zoogeographischen Anmerkungen. Berichte der deutschen wissenschaftlichen Kommission für Meeresforschung, 24, 1-22.

Levrrus, S. (1984) Annual cycle of temperature and heat storage in the World Ocean. Journal of Physical Oceanography, 14, 727-746.

LEVTrUs, S. (1987) Meridional Ekman heat fluxes for the World Ocean and individual ocean basins. Journal of Physical Oceanography, 17, 1484-1492.

LuTJEHARMS, J.R.E. (1981) Features of the southern Agulhas Current circulation from satellite remote sensing. South African Journal of Science, 77, 231-236.

LUTJEHARMS, J.R.E. (1982) Baroclinic volume transport in the Southem Ocean. Journal of Physical Oceanography, 12, 3-7.

LuTJEHARMS, J.R.E. (1985) Location of frontal systems between Africa and Antarctica: some preliminary results. Deep-Sea Research, 32, 1499-1509.

LUTJEHARMS, J.R.E. (1988) Meridional heat transport across the Sub-Tropical Convergence by a warm eddy. Nature, London, 331, 251-254.

LUTJEHARMS, J.R.E. (1989) The role of mesoscale turbulence in the Agulhas Current system. In: Mesoscale/Synoptic Coherent Structures in Geophysical Turbulence, Proceedings of the 20th International Liege Colloquium on Ocean Hydrodynamics, J.C.J. NiHoul and B.M. JAMART, editors, Elsevier Oceanography Series, 50, Amsterdam, 357-372.

LutJeharms, J.R.E., R. CAtzel and H.R. VAlentine (1989) Eddies and other boundary phenomena of the Agulhas Current. Continental Shelf Research, 9, 597-616.

LUTJEHARMS, J.R.E. and A.L. GoRDon (1987) Shedding of an Agulhas ring observed at sea. Nature, London, 325, 138140.

LUTJEHARMS, J.R.E. and H.R. RoBeRTs (1988) The Natal pulse: An extreme transient on the Agulhas Current. Journal of Geophysical Research, 93, 631-645.

LUTJEHARMS, J.R.E. and P.L. STOCKTON (1987) Kinematics of the upwelling front off southern Africa. South African Journal of Marine Science, 5, 35-49.

LUTJEHARMS, J.R.E. and H.R. VALENTINE (1984) Southern Ocean thermal fronts south of Africa. Deep-Sea Research, 31, 1461-1475.

LUTJEHARMS, J.R.E. and H.R. VALENTINE (1987) Water types and volumetric considerations of the south-east Atlantic upwelling regime. South African Journal of Marine Science, 5, 63-71. 
LutJeHARMS, J.R.E. and H.R. VAlENTINE (1988a) On mesoscale ocean eddies at the Agulhas Plateau. South African Journal of Science, 84, 194-200.

LUTJEHARMS, J.R.E. and H.R. VALENTINE (1988b) Eddies at the Subtropical Convergence south of Africa. Journal of Physical Oceanography, 18, 761-774.

LutJehaRMS, J.R.E. and R.C. VAN BaLIegooyen (1984) Topographic control in the Agulhas Current system. DeepSea Research, 31, 1321-1337.

LUTJEHARMS, J.R.E. and R.C. VAN BALEGOOYEN (1988) The retroflection of the Agulhas Current. Journal of Physical Oceanography, 18, 1570-1583.

LUYTEN, J. (1988) Agulhas eddy variability and mean flow fields. Abstract in: SAARI Meeting Report, May 24-26, 1988, Lamont-Doherty Geological Observatory of Columbia University, Palisades, New York, pg. 18.

LUYTEN, J.R., J. PEDLOSKY and H. STOMMEL (1983) The ventilated thermocline. Journal of Physical Oceanography, 13, 292-309.

Mackintosh, N.A. (1946) The Antarctic Convergence and the distribution of surface temperature in Antarctic waters. Discovery Reports, 23, 177-212.

MAGLIOCCA, A., L.B. MIRANDA and S.R. Signorint (1979) Physical and chemical aspects of transient stages of the upwelling at southwest of Cabo Frio (Lat. $23^{\circ} \mathrm{S}$ - Long. $42^{\circ} \mathrm{W}$ ). Boletim do Instituto Oceanografico, Sao Paulo, 28, 37-46.

MASCARENHAS, A.S., JR., L.B. MIRANDA and N.J. Rock (1971) A study of the oceanographic conditions in the region of Cabo Frio. In: Fertility of the Sea, J.D. CostLow, JR., editor, Gordon and Breach, New York, 285-308.

MAZEIKA, P.A. (1967) Thermal domes in the eastern tropical Atlantic Ocean. Limnology and Oceanography, 12,537539.

MAzдIRA, P.A. (1968) Eastward flow within the equatorial current in the eastem South Atlantic. Journal of Geophysical Research, 73, 5819-5828.

MCCARTNEY, M.S. (1977) Subantarctic Mode Water. In: A Voyage of Discovery, M. ANGEL, editor, Pergamon Press, 103-119.

MCCarTneY, M. and J. ZemBa (1988) Thermocline, intermediate and deep circulation in the southwestern South Atlantic. Abstract in: SAARI Meeting Report, May 24-26, 1988, Lamont-Doherty Geological Observatory of Columbia University, Palisades, New York, 28-29.

MCCARTNEY, M.S. and M.E. WoODGATE-JoNEs (1990) A deep reaching anticyclonic eddy in the subtropical gyre of the eastern South Atlantic. Deep-Sea Research (in press).

MCCREARY, J.P., J. PICAULT and D.W. MoORe (1984) Effect of annual remote forcing in the eastern tropical Atlantic. Journal of Marine Research, 42, 45-81.

Mennardus, W. (1923) Meteorologische Ergebnisse der Seefahrt des "Gauss" 1901-1903. Deutsche SüdpolarExpedition 1901-1903, III. Band, Meteorologie I. Band, 1. Hälfte, Heft III, 437-579.

MELLOR, G.L., C.R. MECHoso and E. Kero (1982) A diagnostic calculation of the general circulation of the Atlantic Ocean. Deep-Sea Research, 29, 1171-1192.

MERLE, J. (1980) Variabilité thermique annuelle et interannuelle de l'océan Atlantique équatorial Est. L'hypothése d'un "El Niño" Atlantique. Oceanologica Acta, 3, 209-220.

MERLE, J. and S. ARNAULT (1985) Seasonal variability of the surface dynamic topography in the tropical Atlantic Ocean. Journal of Marine Research, 43, 267-288.

MERLE, J., M. FieUX and P. Hisard (1980) Annual signal and interannual anomalies of sea surface temperature in the eastern equatorial Atlantic Ocean. Deep-Sea Research, GATE (Supplement II), 26, 77-101.

METCALF, W.G. and M.C. Stalcup (1967) Origin of the Atlantic Equatorial Undercurrent. Journal of Geophysical Research, 72, 4959-4975.

MetCalp, W.G., A.D. Voorhis and M.C. Stalcup (1962) The Atlantic Equatorial Undercurrent. Journal of Geophysical Research, 67, 2499-2508.

MiRANDA, L.B. and B.M. Castro FII ho (1982) Geostrophic flow conditions of the Brazil Current at $19^{\circ}$ S. Ciencia Interamericana, 22, 44-48.

MolinaRI, R.L. (1982) Observations of eastward currents in the tropical South Atlantic Ocean: 1978-1980. Journal of Geophysical Research, 87, 9707-9714.

Molinaru, R.L. (1983) Observations of near-surface currents and temperature in the central and western tropical Atlantic Ocean. Journal of Geophysical Research, 88, 4433-4438.

MoLINARI, R.L., B. VorruRIRZ and P. DuNCAN (1981) Observations in the subthermocline undercurrent of the equatorial South Atlantic Ocean: 1978-1980. Oceanologica Acta, 4, 451-456. 
MOORE, D.W. and S.G.H. PrIl_ANDER (1977) Modeling of the tropical oceanic circulation. In: The Sea: Ideas and Observations on Progress in the Study of the Seas, Volume 6:Marine Modeling, E.D. GolDBERG, I.N.McCAVE, J.J. O'BrIEN, and J.H. STEELE, editors, Wiley, Interscience, New York, 319-361.

Moore, D., P.Hisard, J. McCreary, J. Merie,J. O'Brien, J. Picault, J.-M. Verstraete and C. Wunsch (1978) Equatorial adjustment in the eastern Atlantic. Geophysical Research Letters, 5, 637-640.

Moroshin, K.V., V.A. Bubnov and R.P. Bulatov (1970) Water circulation in the eastern South Atlantic Ocean. Oceanology, 10(1), 27-34.

Mossy, H. (1934) The waters of the Atlantic Antarctic Ocean. Scientific Results of the Norwegian Antarctic Expedition, 1927-1928, 11, 1-131.

Nelson, G. and L. Hutchings (1983) The Benguela upwelling area. Progress in Oceanography, 12, 333-356.

Nowl.IN, W.D., JR. and M. CLIFFORD (1982) The kinematic and thermohaline zonation of the Antarctic Circumpolar Current at Drake Passage. Journal of Marine Research, 40 (supplement), 481-507.

NowLIN, W.D., JR. and J.M. KLINCK (1986) The physics of the Antarctic Circumpolar Current. Reviews of Geophysics and Space Physics, 24, 469-491.

Nowlin, W.D., JR., T. WHITWORTH III and R.D. PRLSBURY (1977) Structure and transport of the Antarctic Circumpolar Current at Drake Passage from short-term measurements. Journal of Physical Oceanography, 7, 788-802.

O'BRIEN, J.J., D. AdAMEC and D.W. MoORE (1978) A simple model of upwelling in the Gulf Of Guinea. Geophysical Research Letters, 5, 641-644.

Olson, D.B. and R.H. Evans (1986) Rings of the Agulhas Current. Deep-Sea Research, 33, $27-42$.

Olson, D.B., A. Gordon and S. Hooker (1985) Dynamic description of Brazil/Falkland rings. Abstract in: Eos, 66(18), 291.

Olson, D.B., G.P. Podesta, R.H. Evans and O.B. BRown (1988) Temporal variations in the separation of Brazil and Malvinas currents. Deep-Sea Research, 35, 1971-1990.

OORT, A.H. and T.H. VONDER HAAR (1976) On the observed annual cycle in the ocean-atmosphere heat balance over the northern hemisphere. Journal of Physical Oceanography, 6, 781-799.

OstaPOF, F. (1960) On the mass transport through the Drake Passage. Journal of Geophysical Research, 65, 28612868.

OSTAPOFF, F. (1961) A contribution to the problem of the Drake Passage circulation. Deep-Sea Research, 8, 111-120.

OSTAPOFF, F. (1962) On the frictionally induced transverse circulation of the Antarctic Circumpolar Current. Deutsche Hydrographische Zeitschrift, 15, 103-113.

O'ToOLe, M.J. (1980) Seasonal distribution of temperature and salinity in the surface water off South West Africa, 1972-1974. Investigational Report 121, Sea Fisheries Institute, Department of Agriculture and Fisheries, South Africa, 25 pp.

OU,H.W. and W.P.M. DE RULTER (1986) Separation of an inertial boundary current from a curved coastline. Journal of Physical Oceanography, 16, 280-289.

PAtTerson, S.L. (1985) Surface circulation and kinetic energy distributions in the southem hemisphere oceans from FGGE drifting buoys. Journal of Physical Oceanography, 15, 865-884.

PAtterson, S.L. and H.A. Stevers (1980) The Weddell-Scotia Confluence. Journal of Physical Oceanography, 10, 1584-1610.

PEARCE, A.F. (1977) Some features of the upper $500 \mathrm{~m}$ of the Agulhas Current. Journal of Marine Research,35,731751.

PEARCE, A.F. and M.L. GrondLINGH (1982) Is there a seasonal variation in the Agulhas Current? Journal of Marine Research, 40, 177-184.

PedLosky, J. (1987) An inertial theory of the Equatorial Undercurrent. Journal of Physical Oceanography, 17, 19781985.

Pedlosky, J. (1988) Entrainment and the termination of the Equatorial Undercurrent. Journal of Physical Oceanography, 18, 880-886.

PEDLOSKY, J. and R.M. SAMELSON (1989) Wind forcing and the zonal structure of the Equatorial Undercurrent. Journal of Physical Oceanography, 19, $1244-1254$.

PETERson, R.G. (1986) Abyssal Boundary Current Studies deployment cruise. Antarctic Journal of the United States, 21(5), 125-127.

PETERSON, R.G. (1988a) On the transport of the Antarctic Circumpolar Current through Drake Passage and its relation to wind. Journal of Geophysical Research, 93, 13993-14004.

PETERson, R.G. (1988b) Comparisons of sea level and bottom pressure measurements at Drake Passage. Journal of Geophysical Research, 93, 12439-12448. 
PETERSON, R.G. (1990) On the volume transport in the southwestem South Atlantic Ocean. Abstract in: Eos, 71(17), 542.

Peterson, R.G. and T. WhrTwORTh III (1989) The Subantarctic and Polar fronts in relation to deep water masses through the Southwestem Atlantic. Journal of Geophysical Research, 94, 10817-10838.

PETERSON, R.G., W.D. NowLIN, JR. and T. WHITWORTH III (1982) Generation and evolution of a cyclonic ring at Drake Passage in early 1979. Journal of Physical Oceanography, 12, 712-719.

PHILANDER, S.G.H. (1973) Equatorial Undercurrent: measurements and theories. Reviews of Geophysics and Space Physics, 11, 513-570.

PhILANDER, S.G.H. (1986) Unusual conditions in the tropical Atlantic Ocean in 1984. Nature, London, 322, 236-238.

PHILANDER, S.G.H. and R.C. PACANowski (1984) Simulation of the seasonal cycle in the tropical Atlantic Ocean. Geophysical Research Letters, 11, 802-804.

PhILANDER, S.G.H. and R.C. PACANowsKI (1986a) A model of the seasonal cycle in the tropical Atlantic Ocean. Journal of Geophysical Research, 91, 14192-14206.

PHILANDER, S.G.H. and R.C. PACANOWSKI (1986b) The mass and heat budget in a model of the tropical Atlantic Ocean. Journal of Geophysical Research, 91, 14212-14220.

PIOLA, A.R. and A.A. BIANCHI (1990) Geostrophic mass transports at the Brazil/Malvinas Confluence. Abstract in: Eos, 71(17), 542.

PIOLA, A.R. and D.T. GEORGI (1982) Circumpolar properties of Antarctic Intermediate Water and Subantarctic Mode Water. Deep-Sea Research, 29, 687-711.

ProLA, A.R. and A.L. Gordon (1989) Intermediate waters in the southwest South Atlantic. Deep-Sea Research, 36, $1-16$.

Rasmusson, M. and J.M. WALACE (1983) Meteorological aspects of the El Niño/Southern Oscillation. Science, 222, 1195-1202.

REID, J.L., JR. (1964a) Evidence of a South Equatorial Counter Current in the Atlantic Ocean in July 1963. Nature, London, 203, 182.

REID, J.L., JR. (1964b) A transequatorial Atlantic oceanographic section in July 1963 compared with other Atlantic and Pacific sections. Journal of Geophysical Research, 69, 5205-5215.

REID, J.L. (1989) On the total geostrophic circulation of the South Atlantic Ocean: Flow patterns, tracers and transports. Progress in Oceanography, 23, 149-244.

REID, J.L. and W.D. NowlIN, JR. (1971) Transport of water through the Drake Passage. Deep-Sea Research, 18, 5164.

REDD, J.L., W.D. NowL.N, JR. and W.C. PATzERT (1977) On the characteristics and circulation of the southwestern Atlantic Ocean. Journal of Physical Oceanography, 7, 62-91.

RENNELL, J. (1832) An investigation of the currents of the Atlantic Ocean, and of those which prevail between the Indian Ocean and the Atlantic. J.G.\&F. Rivington, London, 299 pp., 2 plates.

REVERDIN, G. and M.J. MCPHADEN (1986) Near-surface current and temperature variability observed in the equatorial Atlantic from drifting buoys. Journal of Geophysical Research, 91, 6569-6581.

RICHARDSON, P.L. and D. WALSH (1986) Mapping climatological seasonal variations of surface currents in the tropical Atlantic using ship drifts. Journal of Geophysical Research, 91, 10537-10550.

RINKEL, M.O., P. SUND and G. NEUMANN (1966) The location and termination area of the Equatorial Undercurrent in the Gulf of Guinea based on observations during Equalant III. Journal of Geophysical Research, 71, 38933901.

RINTouL, S.R. (1990) South Atlantic interbasin basin. Journal of Geophysical Research, (in press).

RoBinson, A.R. and P.P. NmleR (1967) The theory of free inertial currents: I. Path and structure. Tellus, 19, 269-291.

RoDEN, G.I. (1986) Thermohaline fronts and baroclinic flow in the Argentine Basin during the austral spring of 1984. Journal of Geophysical Research, 91, 5075-5093.

RoDEN, G.I. (1989) The vertical thermohaline structure in the Argentine Basin. Journal of Geophysical Research, 94, 877-896.

ROEMMICH, D. (1983) The balance of geostrophic and Ekman transport in the tropical Atlantic Ocean. Journal of Physical Oceanography, 13, 1534-1539.

SARMIENTO, J.L. (1986) On the North and tropical Atlantic heat balance. Journal of Geophysical Research,91, 1167711689.

SCHELL, I.I. (1968) On the relation between the winds off South West Africa and the Benguela Current and Agulhas Current penetration in the South Atlantic. Deutsche Hydrographische Zeitschrift, 21, 109-117. 
SCHEMAINDA, R. (1980) Ergebnisse ozeanologischer Untersuchungen mit dem FFS "Ernst Haeckel" im Konvergenzgebiet von Brasil- und Falklandstrom im Juni/Juli 1978. Beiträge zur Meereskunde, 44/45, 109-121.

Schотт, G. (1902) Oceanographie und maritime Meteorologie. Wissenschaftliche Ergebnisse der Deutschen TiefseeExpedition Valdivia 1898-1899, 1, 403 pp., 26 plates.

Schotт, G. (1926) Geographie des Atlantischen Ozeans. C. Boysen, Hamburg, 368 pp., 28 plates.

SERVAIN, J., J. PICAULT and J. MERLE (1982) Evidence of remote forcing in the equatorial Atlantic Ocean. Journal of Physical Oeanography, 12, 457-463.

ShanNon, L.V. (1966) Hydrology of the south and west coasts of South Africa. Investigational Report 58, Division of Sea Fisheries, South Africa, 52 pp.

Shannon, L.V. (1985) Description of the Ocean Colour and Upwelling Experiment. In: South African Ocean Colour and Upwelling Experiment, L.V. SHANnon, editor, Sea Fisheries Research Institute, South Africa, 1-12.

Shannon, L.V., J.J. AgenBaG and M.E.L. BuYs (1987) Large- and mesoscale features of the Angola-Benguela Front. South African Journal of Marine Science, 5, 11-34.

Shannon, L.V., A.J. Boyd, G.B. Brundrit and J. Taunton-Clark (1986) On the existence of an El Niño-type phenomenon in the Benguela system. Journal of Marine Research, 44, 495-520.

Shannon, L.V. and M. van Ruswuck (1969) Physical oceanography of the Walvis Ridge region. Investigational Report 70, Division of Sea Fisheries, South Africa, 19 pp.

SHANNon, L.V., J.R.E. LuTJEHARMS and J.J. AGENBAG (1989) Episodic input of subantarctic water into the Benguela region. Suid-Afrikaanse Tydskrif vir Wetenskap, 85, 317-322.

SIRDLER, G. (1983) Tropical and equatorial regions. In: Eddies in Marine Science, A.R. RoBINSON, editor, SpringerVerlag, 181-199.

SiedLeR, G., and S.G.H. PhILANDer (1982) Physics of the upper tropical ocean. In: The GARP Atlantic Tropical Experiment (GATE) Monograph, WMO, Geneva, GARP Publication Series, 25, 219-235.

SIEVERS, H.A. and W.J. EMERY (1978) Variability of the Antarctic Polar Frontal Zone in Drake Passage - summer 1976-1977. Journal of Geophysical Research, 83, 3010-3022.

SIEVERS, H.A. and W.D. Nowlin, JR. (1984) The stratification and water masses in Drake Passage. Journal of Geophysical Research, 89, 10489-10514.

SignoRIN, S.R. (1978) On the circulation and the volume transport of the Brazil Current between the Cape of São Tomé and Guanabara Bay. Deep-Sea Research, 25, 481-490.

SмITH, S.G. (1989) On the Weddell-Scotia Confluence and the Scotia Front. M.S. thesis, Texas A\&M University, College Station, 85 pp.

Stander, G.H. (1964) The Benguela Current off South West Africa. Investigational Report 2, Marine Research Laboratory, South West Africa, 43 pp.

StANDER, G.H. and A.H.B. De DeCKER (1969) Some physical and biological aspects of an oceanographic anomaly off South West Africa in 1963. Investigational Report 81, Division of Sea Fisheries, South Africa, 46 pp.

Stommel, H. (1957) A survey of ocean current theory. Deep-Sea Research, 4, 149-184.

Stramma, L. (1989) The Brazil Current transport south of $23^{\circ} \mathrm{S}$. Deep-Sea Research, 36, 639-646.

STRAMMA, L. and R.G. Peterson (1989) Geostrophic transport in the Benguela Current region. Journal of Physical Oceanography, 19, 1440-1448.

Stramma, L. and R.G. Peterson (1990) The South Atlantic Current. Journal of Physical Oceanography, 20, 846859.

StRamma, L., Y. Ikeda and R.G. Peterson (1990) Geostrophic transport in the Brazil Current region north of $20^{\circ}$ S. Deep-Sea Research (in press).

STURM, M. and K. Vorgt (1966) Observations of the structure of the Equatorial Undercurrent in the Gulf of Guinea in 1964. Journal of Geophysical Research, 71, 3105-3108.

Sverdrup, H.U., M.W. Johnson and R.H. Fleming (1942) The Oceans. Prentice Hall, 1087 pp.

TAFT, B.A. (1963) Distribution of salinity and dissolved oxygen on surfaces of uniform potential specific volume in the South Atlantic, South Pacific, and Indian oceans. Journal of Marine Research, 21, 129-146 (text), 567579 (figures).

TAunton-Clark, J. and L.V. Shannon (1988) Annual and interannual variability in the south-east Atlantic during the 20th century. South African Journal of Marine Science, 6, 97-106.

TCHERnia,P. (1980) Descriptive Regional Oceanography. PergamonMarine Series Volume 3, Pergamon Press, Oxford, 253 pp., 19 plates.

TsuchIYA, M. (1985) Evidence of a double-cell subtropical gyre in the South Atlantic Ocean. Journal of Marine 
Research, 43, 57-65.

TsuchryA, M. (1986) Thermostads and circulation in the upper layer of the Atlantic Ocean. Progress in Oceanography, 16, 235-267.

van Loon, H. (1972) Half-yearly oscillations in the Drake Passage. Deep-Sea Research, 19, 525-527.

VERONIS, G. (1973) Model of World Ocean circulation: I. Wind-driven, two-layer. Journal of Marine Research, 31, 228-288.

VERONIS, G. (1978) Model of World Ocean circulation: III. Thermally and wind driven. Journal of Marine Research, 36, 1-44.

VISSER, G.A. (1969) Hydrological observations in the south-east Atlantic Ocean. Investigational Report 77, Division of Sea Fisheries, South Africa, 23 pp.

VorturIEZ, B. (1981) Les sous-courants équatoriaux nord et sud et la formation des dômes thermiques tropicaux. Oceanologica Acta, 4, 497-506.

VorturiEZ, B and A. HerrbLAND (1982) Comparaison des systèmes productifs de l'Atlantique Tropical Est: dômes thermiques, upwellings côtiers et upwelling équatorial. Rapports et Procès-Verbaux des Réunions Conseil International pour l' Exploration de la Mer, 180, 114-130.

VOROB' YEv, V.N. and B.V. GINDYSH (1965) Magnitude of mass and heat transport through Drake Passage. Soviet Antarctic Expedition Information Bulletin, 5, 425-428.

WACONGNE, S. (1989) Dynamical regimes of a fully nonlinear stratified model of the Atlantic Equatorial Undercurrent. Journal of Geophysical Research, 94, 4801-4815.

WACONGNE, S. and B. PTTON (1990) Current measurements along the coasts of Gabon and Congo and relevance to the larger scale circulation. Deep-Sea Research (submitted).

WARREN, B.A. (1963) Topographic influences on the path of the Gulf Stream. Tellus, 15, 167-183.

WAUTHY, B. (1977) Révision de la classification des eaux de surface du golfe de Guinée (Berrit 1961). Cahiers O.R.S.T.O.M., série Océanographie, XV, 279-295.

WEARN, R.B. and D.J. BAKER, JR. (1980) Bottom pressure measurements across the Antarctic Circumpolar Current and their relation to the wind. Deep-Sea Research, 27, 875-888.

WexLER, H. (1959) The Antarctic Convergence - or Divergence? In: The Atmosphere and Sea in Motion, Rossby Memorial Volume, B. BolIN, editor, Rockefeller Institute Press, New York, 107-120.

WhrTwORTH, T., III (1980) Zonation and geostrophic flow of the Antarctic Circumpolar Current at Drake Passage. Deep-Sea Research, 27, 497-507.

WhrTwORTH, T., III (1983) Monitoring the transport of the Antarctic Circumpolar Current at Drake Passage. Journal of Physical Oceanography, 13, 2045-2057.

WHITWORTH, T., III and W.D. NowLIN, JR. (1987) Water masses and currents of the Southern Ocean at the Greenwich Meridian. Journal of Geophysical Research, 92, 6462-6476.

WhITwORTH, T., III and W.D. NowhIN JR. (1990) The Antarctic Circumpolar Current and deep western boundary current in the southwest Atlantic. Abstract in: Eos, 71(17), 544-545.

WHTTWORTH, T., III, W.D. NOWLIN JR. and S.J. WORLEY (1982) The net transport of the Antarctic Circumpolar Current through Drake Passage. Journal of Physical Oceanography, 12, 960-971.

WhITwORTH, T., III and R.G. PEterson (1985) The volume transport of the Antarctic Circumpolar Current from bottom pressure measurements. Journal of Physical Oceanography, 15, 810-816.

Wooster, W.S. and J.L. ReIn, JR. (1963) Eastern boundary currents. In: The Sea, Volume 2, M.N. HIL, editor, Interscience, London, 253-280.

World METEORological Organization (1963) Fourth World Meteorological Congress, Resolution 35. WMO No. $142,79-80$ and $157-166$.

World Metrorological Organzzation (1977) Guide to marine meteorological services. WMO 471, $155 \mathrm{pp}$.

WüsT, G. (1928) Der Ursprung der atlantischen Tiefenwässer. In:Zeitschrift der Gesellschaft für Erdkunde zu Berlin, Sonderband zur Hundertjahrfeier der Gesellschaft, Berlin, 551 pp., 41 plates.

Wost, G. (1935) Schichtung und Zirkulation des Atlantischen Ozeans. Die Stratosphäre. Wissenschaftliche Ergebnisse der Deutschen Atlantischen Expedition auf dem Forschungs- und Vermessungsschiff 'Meteor' 1925-1927, 6: Teil 1, Lieferung 2, 1-288.

Wost, G. (1957) Stromgeschwindigkeiten und Strommengen in den Tiefen des Atlantischen Ozeans. Wissenschaftliche Ergebnisse der Deutschen Atlantischen Expedition Forschungs- und Vermessungsschiff Meteor 1925-1927, 6 (2), 261-420.

WYrTKI, K. (1960) The Antarctic Circumpolar Current and the Antarctic Polar Front. Deutsche Hydrographische 
Zeitschrift, 3, 153-173.

WYRTKI, K. (1971) Oceanographic Atlas of the International Indian Ocean Expedition. National Science Foundation, Washington, D.C., $531 \mathrm{pp}$.

WYRTKI, K., L. MAGAARD and J. HAGER (1976) Eddy energy in the oceans. Journal of Geophysical Research, 81, 2641 2646.

ZEMBA, J.C. and M.S. MCCARTNEY (1988) Transport of the Brazil Current: it's bigger than we thought. Abstract in: Eos, 69(44), 1237.

ZYRYANOv, V.N. and D.N. Severov (1979) Water circulation in the Falkland - Patagonia region and its seasonal variation. Oceanology, 19, 518-522. 